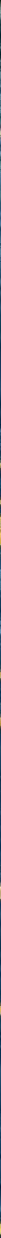

Who?

THE CALL OF THE SEA $\triangle$ PROSE ANTHOLOGY 


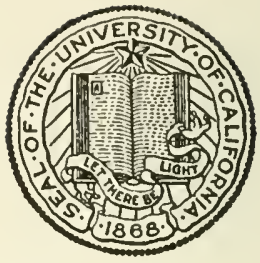

THE LIBRARY

OF

THE UNIVERSITY

OF CALIFORNIA

LOS ANGELES

.

20

-5त्tol

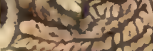

"is entrity

Whe the

- $15-125$ ?

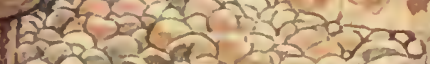
$150-40.609$

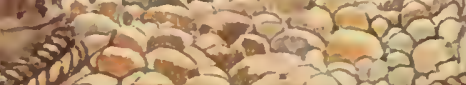

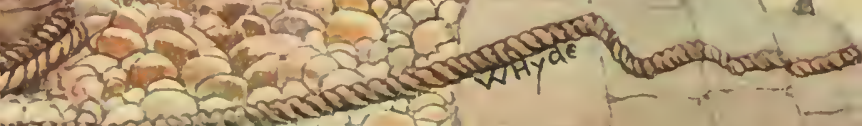

5.716ि

$x \rightarrow-x+5 x+2 y<<$ 


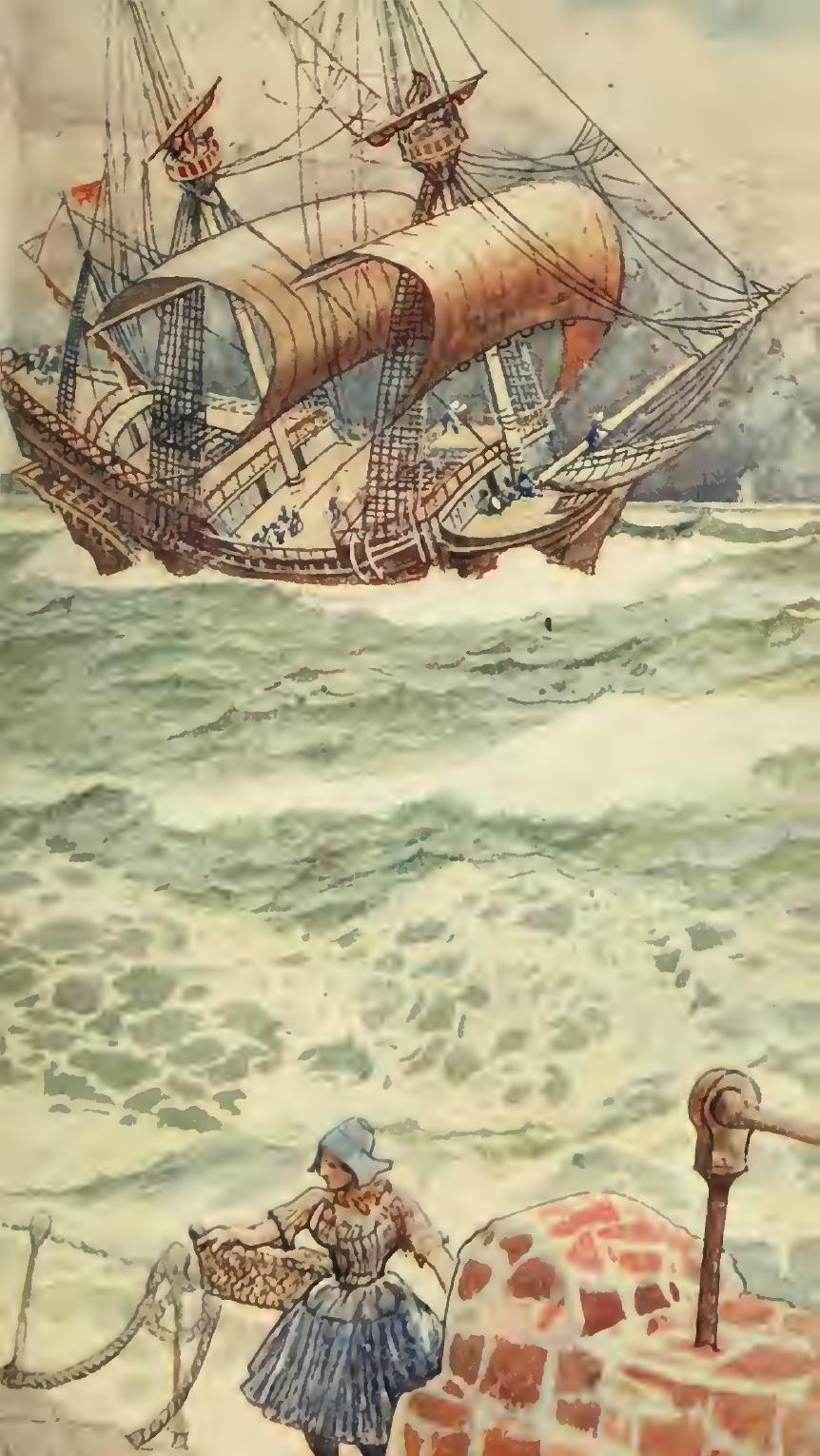



THE CALL OF THE SEA 
UNIFORM WITH THIS VOLUME TRAVELLER'S JOY

Compiled by W. G. Waters

Second Edition

THE POCKE'T BOOK OF POEMS AND SONGS FOR THE OPEN AIR

COMPILEd by EDHard Thomas

E. GRANT RICHARDS 


\title{
THE CALL
}

OF THE SEA

A PROSE ANTHOLOGY

\author{
COMPILED BY \\ F. G. AFLALO
}

And the gathering logether of the waters called he scas.

GENE ils I. זо

And there was no more sea.

IRV. $x \times 1$. I

\section{I.ONDON}

E. GRANT RICHARISS

1907 



\section{GC \\ 21 \\ $\mathrm{A}_{25 c}$}

DEDICATED IN AFFECTIONATE ADMIRATION To

WILLIAM CLARK RUSSELL

DOYEN OF LIVING WRITERS ON TIIE SEA

BY

TIIE AUTHOR 
Digitized by the Internet Archive in 2008 with funding from Microsoft Corporation 


\section{PREFACE}

SINS of omission and commission are the way of every compiler of anthologies, and without doubt this little collection has its share. I can only plead that these are no result of carelessness, but purely of faulty taste, for the passages herein gathered are the result of much weighing, the residue after much sifting, and at any rate I hope that, even though the reader is certain to object to some of my choice, and to regret the absence of favourites of his own, he will bear in mind the difficulties of selection, having in view a moderate compass for the whole.

A word is needed with reference to the translations from the classics. To the classical scholar, translation of Homer is heresy. The "modern sicle" would be equally affronted with the original only. There was no room for both. The choice had to be made, and perhaps my choice has been the wrong onc.

It may be complained that writers like Mr. Clark Russell and Captain Marryat are very poorly represented, but one aim of this anthology has been to offer as murh variety of authorship as 
was found compatible with other considerations. Otherwise, a volume of the same bulk, and approximately of the same range, might without great difficulty have been compiled from the voluminous writings of either writer.

The Call of the Sea has a more than abstract meaning for one in whose ears it sings all through the year, and the garnering of these extracts within a hundred yards of its surf has lent enjoyment to the task, which has been indeed no task, but a recreation. In its original form, the collection was to have included poetry, but this was anticipated by the admirable "Sailor's Garland" of Mr. Masefield, who has for the time being most generously dropped anchor in a large prose sister ship that my little craft may have the fair-way to herself.

To the publishers, and in many cases also to the authors, named in the following list, I owe my thanks for permission to make use of the material included in the book, and my gratitude must take a more personal turn when I recall the kind assistance and encouragement given to me by $\mathrm{Mr}$. Hilaire Belloc, M.P., Mr. Frank Bullen, Mr. Robert Hichens, Mr. Rudyard Kipling, Mr. Eden Phillpotts, Mr. Morley Roberts, Mr. Clark Russell, Mr. Basil Soulsby (Hon. Sec. to the Hakluyt Society, with permission to use many extracts from its valuable reprints), and $\mathrm{Mr}$. H. G. Wells. 


\section{TABLE OF CONTENTS}

I

THE ANCIENTS AND THE SEA

Seafarers . . The Bible . . 2

The Egyptians IN THE

RED SEA . . The Bible . . 3

SIIPWRECK . . . The Bible . . 4

The Voyage of Ulysses Homer . . . 10

Counsel for Mariners Hesiod . . . 14

THE DAWN OF NAViga.

rion. . . Lucretius . . 15

SHMWRECK . . . Virgil . . . 16

A Stormy Voyage . Ovid . . . 20

For the FismerMan . Ovid . . . . 23

II

THE CHARACTER OF TILE SEA

THE IMMENSE . . Joseph Addison • . 26

TIE: DISTURBER . . Filson Youn's . . 27

THE UNSYMPATHETlC . Filson Young . . 28

THE Terrible . . Edrisi . . . 3 [

THE INERT . . . E. de Amicis . . 31

Tur Boundisiss . . Von Humbolilt • . 33

Tue Excitabie . . P. F.X. de Charlivoix. 33

Tie. IMAGe of IT . John liuskin . 34

How to Past It. . K. da Vinci . . 35

Tilk Cunning, . . Victor Ilugo . . $3^{6}$

Tire Malicious . Joseph Comral • . 36

Tur Oparue. . . Charles kimgsley. . 37

A 2 ix 
The Coast-line . . H. D. Thoreale . . 40 PERSIECTIVE OF THE

CliffS. . . Alice Meynell . . $4 \mathrm{I}$ The Cliffs of Devon . Eden Phillpotts . . 43 The Cliffas of Scotland Sir Walter Scott. . 45 An Essex Sea-Marsh. Rev. S. Baring-Could. 46 A Sea Catern . George Macdonald . 48

\section{IV}

NIGHT AND DAY

Night in a Harbour. Charles kingsley. . 50 Night on a Stramer . R. L. Stevenson . - 51 Night in a Cornish Port Eden Phillpotts . . 52 Night ON THE MEDITER-

RANEAN . * A. M. L. Lamartine 53 DAWN ON THE ICELAND BANKS . - Pierre Loti. - 54 DAWN IN THE LIGHT. IIOUSE . . Rudyard Kipling . $5^{6}$ DAWN IN TIIE LIGHThOUSE . . . Filson Young . . 58 Dawn ON A Cargo boat Morley lioberts . 59

WEATHER

\section{CALM}

A Rougin Crossing • Colonel Hawker . 62 Calm on the Mediter-

$$
\text { RANEAN . . A. M. L. Lamartine . } 63
$$
The Mystery of a CALM F. T: Bullen. . . 64 CiLM OFF TIIE HORN . John Hasefield • . 66 
1I. CHANGE OF WEATHER

Ix tre Soutu Seas . Pierre Loti.

Th: IVAlls of GReV . Jack London - 70

IV. STORM

THE SORROWFUL MAISTER'S

PrEDICAMENT . . William Lithgoze 71

The Fires of St. Elmo P. F. de Quiros . 72

THE FURY OF IT . . Chrislopher Columbus. 77

Scylla and Charybdis François Rabelais . 75

COLLISION BETWEEN TIIE "ERLBUS" $\triangle$ ND

"TERror". . . Sir James lioss . . 76

A Landsian in a Sroril J. Arago . . . 78

Helplessiess OV THE

Sull. . . . 80

A. EMIGRANT SHII IN BAD WVEATIER . Friedrich Gerstaecler . 82

Tul Brbakixg; IVAve. Nichael Scoll . 85

RESPONSIBILITY OF TIH:

IIRlasman. . F. T. Bullen . . 89

Tre Fieet in a Sizuall Tobias Smollill . . 90

Tue Slave Surp • · John Ruskin . . 92

Ligutnisig at Sea . Caplain Marryal . 94

Ligitining at Sea . Wh. Clark kussell - 95

TIIE, IIEIGIIT OF THE

Stors. . Fenimore Cooper. . $9^{8}$

Grirks in a Storm . A. W. Kinglatic. 98

OFF CAPE HORN . . W. I. SHotu . . IOI

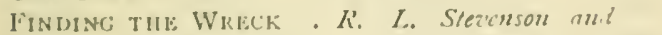

I.loyd Osbourne $\quad 103$

Calis AFTER STORM .J. C. lin Dyke . 107 


\section{VI}

SIIPS ANI SEA TRAVEL

PAGE

Nautical Language . Jonathan Swift . . I Io SIGNS OF LAND . . Christopher Columbus. II I

THE LAST VOYaGe OF

Christopher Colum-

BUS . . . Filson Young . . II2

The Benefits of Navi-

Gation . . . Mrobisher . II4

The Benefits of Navi-

Gation . . W. Barents . . II4

The Benefits of Navi-

Gation . . John Davis, The Navisator . . II6

The Lateen Sall. . Hilaire Belloc. . II7

The Modern Steamship J. C. Van Dyke . . 122

The Modern Steamsirip Joseph Conrad . . I24

The Modern Steamship E. de Amicis . . I26

The Modern Steamship H. G. Wells . . I28

RUNNING BEFORE THF

WIND . . . J John Masefield . . 129

A Day on the Ocean . Rudyard Kipling . 132 PAINS OF EARLY SEA

Travel . . Ferdinand Magellan . I33

Charm of a SEa Voyage Washington Irving . I35

LIFE ON BOARD SHIP . Charles Darwin . . 136

The Channel Crossing Charles Dickens . . 139

The Channel Crossing K. S. Surtecs . . I44

The Atrantic Passagk Charles Dickens. . 146

Leaving tile Thanes . Sir F. Treves . . I48

A Canoe at Sea . John Macgregror . 149 


\section{VII}

\section{LIFE IN THE SEA}

VARIETY OF TYPES

VARIETY OF TYPES

- Philip Gosse

PAGE

BONitoes A.ND FLyiNG

FISH . . . J. Hawkins. . 154

Bonitoes AND FlyiNG

Fisil . . Franfois Pyrart. 157

Bonitoes AND FLYING

Fisu. . . Linschoten . . 158

Mystery of the Ocean Sir Walter Scoll . . I 58

VICTORY OF TIIE CORAL-

BUILDERS. . Charles Darvin . . 160

TuE Sea-Garden . . C. $F$. Holder . . I6I

The Bottom of the Sea fules Verne. . . 164

Tue Воттом of tile Sea Alexander Agassiz . 168

Tife Botton of tile Sea $F$. $T$. Bullen . 170

ABUNDANCE OF FISH IX

THE SisA . . Henry Fielling

.171

\section{VIII}

\section{SEA FIGHTS}

Tue Dizon Masilfrs . Charles kingsley. 174

Salamis . . . Merodotus . . 175

Salamis . . . Mischyiur . . . 180

Syracuse . . . Thucydides. . 184

Sluys . . Holinshed. . I8S

VASCO IIA Gama nengatis

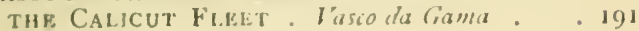


xiv THE CALL OF THE SEA

PAGF:

Lepanto. . . John Lothrop Motley . 195

The Spanish armada. Jimes Amthony frowde 198

DEATH OF SIR RICHARD

Grenville. . . .irsihoten . . 206

LA Hogue . . . Thomas Babington Macaulay. . 208

Trafalgar . . Robert Southey . . 213 AFFAIR OF THE "CHE-

SAPEAKE" AND "SHAN-

NON". . . .J. A. Manson . . 228

\section{ENVOI}

TheSallor's Graveyarn Robert Hichens . . 235 


\title{
AUTHORS QUOTED
}

\author{
AUTHORS WORKS QUOTED PUBLISHERS
}

ADDISON, JOSEPJI Spectator

$(1672-1719)$

Ascirylus (B.c. The Persians Bell
(trans.)

Agassiz, A. (1835- Three Cruises of Sampson Low

ARAGO, J.

the "Blake"

Voyage Round the

World (trans.)

BARENTS, IV. ( - Three Voyages to Ilakluyt 1597) theArctickegions Suciety (trans.)

BARING-GoULD,
Rev. S. $\left(1834^{-}\right)$

Belloc, IILAire Esto Perpetua Duckworth ( $1870-)$

Bulles, F. T. $(1857$ The Cruise of the Smith Elder - ) "Cachalot"

A Sack of Shakings C. A. Pearson

Cinarlevolx, P. I. History of Sinto XAVIRR DE (ifixz Domingo (trais.) $-1752)$

Columsus, Curis- Jourmul (trans.) TOPIIIK (' I4401506)

Conkad, Josinil The Mirror of the Methuen Sea 
AUTHORS

COOPER, JAMES

FENIMORE ( $17 \mathrm{~S}^{\circ-}$ 185x)

DA Gaina, Vasco (? 1469-1524)

Darivin, Charles (I809-1882)

DA VINCI, LEONARDO (1452-1519)

DAvis, J. ("The Navigator") (? $1550-1605$ )

De Amicis, E. (184ó Sull Oceano - )

DE Quiros, Pedro FERNANDES (? $1560-1614)$

Dickens, Chardes The Uncommercial (1812-1870)

EDRISI

Fielding, HeNRY (1707-1754)

Frobisiner, SIR Three Voyages MARTIN ( 1594)

FroUde, JAMFS ANTHONY (1818189.1)

Gerstaecker, FrIEDRICII (18161872)

Gosse, 1'nulm H. Nuturalist of the Heinemann (1810-1888) Sea Shore Trazieller American Noles A Description of Spain (trans.)

PUBLISIIERS

Hakluyt Sociely

Jolin Murray

Duckworth

Hakluyt Society

Fratelli Neves

Hakluyt Society

Chapnan and Hall

Jakluyt Society

History of Englend Longman

Blau II'asser 
AUTHORS

WORKS QUOTED

PUBLISHEKS

HaWker, Colonel Diaries

Longmans

PETER (1;86-1853)

Hawkins, SiR J. Voyages (1532-1595)

HERODOTL'S (? ab. $48+-424$ B.c.)

HESIOD (? ab. 735 B.C.) History (trans.)

Hakluyt

Soci-ty

bell

Bell

Hichens, Robert Tongues of Con- Methuen (1864science

HOLDER, C. F. The Log of a Sea- Coustable Angler

HOLINSHED ( - Chronicles $1580)$

HOMEK (?)

HUGo, Victor (1802-1885)

The Odyssey'(trans.) Bell

Les Travailleurs de Hetze! la. Mer

HUMBOLDT, BARON Cosmos (trans.) VoN $(1769-1859)$

IrVING, WASHiNG- The Sketch Book TON $(1783-1859)$

KINGLAKE, A. W. FEothen (1809-1891)

Kingsley, Cimarles (18.9-1875)

KIILING, RUDYARD $(1865)$

I.AMARTINE, $\Lambda$ LPIIONSE MARHP: Lolis (1790-1869)

LINSCHOTE.N

At Last

Macmillan H'estruard /lo!

$\left.\begin{array}{l}\text { Many Inventions } \\ \text { Captains Courage- } \\ \text { ous }\end{array}\right\}$ Macmillan Voyage en Oricnt

Inyage to the Fast llakluyt Indies (trana.) Suciety

l.mHgow, Windiss Rave delventures $(15 \times 2-1645$ ?) 


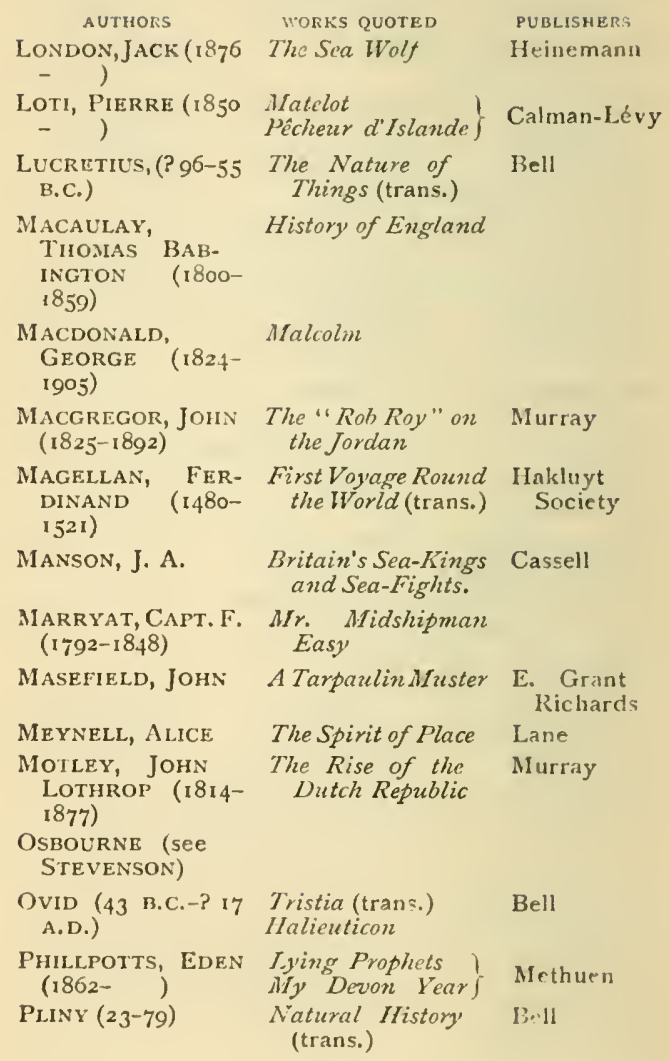


AUTHORS QUOTED

AUTHORS

PYRARD, F.

RABELAIS COIS (? $\left.1495^{-1} 553\right)$

WORKS QUOTED

Voyage (trans.)

The Fifth Book of

the Good Pantagruel (trans.)

Roberts, MORLEY A Tramp's Note$\left(1857^{-}\right)$ book

Koss, Sir James 1 Voyage of Dis$(1800-1862)$ covery

RUSKIN, JOHN (1819 $-1900)$

\section{Modem Painters} The IIarbours of
England

RUSSELL, WILLIA:I Clark (1844- )

The Wreck of the "Grosvenor"

Scott, Micinel The Cruise of the $(1789-1835)$ " Midge"

Scott, SirWalter The Pirate $(1771-1832)$

SMOLLET, TOBIAS Roderick Random $(1721-1771)$

SNow, W. I'. A Two Years Cruise of Tierra del

Southi:y, Robert life of Nelsom

$$
\text { (1774-1843) }
$$

Sievenson, R. I. Essays of Travel $(1850-1894)$

STEVENSON, R. L. The Hrecker and LLOY! OSHOURNE ( $1868-$ )

SURTERS, ROBZRT Jarrocks's Jaunts Simin( -1863) and Jolluties

Sw1F, JoNimax Gullizer's Fravels $(166 \vec{i}-174.5)$ $\mathrm{xix}$

PUBLISHENS

Hakluyt

Society

F. K. White

Hakluyt

Society

Allen Sampson Low

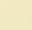


THOREAU, H. D.

$(1817-1862)$

Thucydides (? $47 \mathrm{I}$ /Histary of the Pelo- Bell

-? 40 1 B.C.) ponnesizn IVar (trans.)

Treves, Sir F. The Other Side of Cassell (1853- ) the Lantern

VAN Dyke, J. C. The Opal Sea

VERNE, JULES ( 1828

Vingt Mille Iieues sous les Mers*

VIRGIL (70-I9 B.c.) The Aneid (trans.) T. Wernor Laurie

Wells, H. G. (1866 The Future in Chapman and - ) America Hall

Young, Filson Christopher Colum- E. Grant bus Richards

The Sands of Plea- ditto sizre

Ireland at the

Cross Roads

* One of the Series of the "Voyages Extraordinaires" of Jules Verne, published by Messrs. Hetzel. 
I

THE ANCIENTS AND THE SEA 
They that go down to the sea in ships, and occupy their business in great waters;

These men see the works of the Lord, and His wonders in the deep.

For at His word the stormy wind ariseth, which lifteth up the waves thereof.

They are carried up to the heaven, and down again to the deep: their soul inelteth away because of the trouble.

They reel to and fro, and stagger like a drunken man, and are at their wits' end.

So when they cry unto the Lord in their trouble He delivereth them out of their distress.

For He maketh the storm to cease, so that the waves thereof are still.

Then are they glad because they are at rest; and so He bringeth them unto the haven where they would be.

Psalm cvir. 


\section{The Egyptians in the Red Sea}

(From Exorlus xiv, 21-22, 26-29)

\section{A ND Moses stretched out his hand over the} sea; and the Lord caused the sea to go back by a strong east wind all that night, and made the sea dry land, and the waters were divided.

And the children of Israel went into the midst of the sea upon the dry ground: and the waters were a wall unto them on their right hand, and on their left. . . .

And the Lord said unto Moses, Stretch out thine hand over the sea, that the waters may come again upon the Egyptians, upon their chariots, and upon their horsemen.

And Moses stretched forth his hand over the sea, and the sea returned to his strength when the morning appeared; and the Egyptians fled against it; and the Lord overthrew the Egyptians in the Inidst of the sea.

And the waters returned, and covered the chariots, and the horsemen, and all the host of Pharaoh that came into the sea after them; there remained not so much as one of them.

But the children of Isracl walked upon dry land in the midst of the sea; and the waters were a wall unto them on their right hand, and on their left. 


\section{Shipwreck}

(From Jonah I. 4-5, 12-13)

$\mathrm{B}^{\mathrm{UT}}$ the Lord sent out a great wind into the sea, and there was a mighty tempest in the sea, so that the ship was like to be broken.

Then the mariners were afraid, and cried every man unto his god, and cast forth the wares that were in the ship into the sea, to lighten it of them. But Jonah was gone down into the sides of the ship; and he lay, and was fast asleep. ...

And he said unto them, Take me up and cast me forth into the sea; so shall the sea be calm unto you: for I know that for my sake this great tempest is upon you.

Nevertheless the men rowed hard to bring it to the land; but they could not : for the sea wrought, and was tempestuous against them.

\section{(From Matthew vili, 23-27)}

And when he was entered into a ship, his disciples followed him.

And, behold, there arose a great tempest in the sea, insomuch that the ship was covered with the waves: but he was asleep.

And his disciples came to him and awoke him, saying, Lord, save us : we perish.

And he saith unto them, Why are ye fearful, $O$ ye of little faith? Then he arose and rebuked 
the winds and the sea; and there was a great calm.

But the men marvelled, saying, What manner of man is this, that even the winds and the sea obey him!

\section{(From Acts xxvi1.)}

And when it was determined that we should sail into Italy, they delivered Paul and certain other prisoners unto one named Julius, a centurion of Augustus' band.

And entering into a ship of Adramyttium, we launched, meaning to sail by the coasts of Asia; one Aristarchus, a Macedonian of Thessalonica, being with us.

And the next day we touch at Sidon. And Julius courteously entreated I'aul, and gave him liberty to go unto his friends to refresh himself.

And when we had launched from thence, we sailed under Cyprus, because the winds were contrary.

And when we had sailed over the sea of Cilicia and Pamphylia, we came to Myra, a city of Lycia.

And there the centurion found a ship of Alexandria sailing into Italy ; and he put us therein.

And when we had sailed slowly many days, and scarce were come over against Cnidus, the wind not suffering us, we sailed under Crete, over against Salunone; 
And, hardly passing it, came unto a place which is called The fair havens; nigh whereunto was the city of Lasea.

Now when much time was spent, and when sailing was now dangerous, because the fast was now already past, Paul admonished them, And said unto them, Sirs, I perceive that this voyage will be with hurt and much damage, not only of the lading and ship, but also of our lives.

Nevertheless the centurion believed the master and the owner of the ship, more than those things which were spoken by Paul.

And because the haven was not commodious to winter in, the more part advised to depart thence also, if by any means they might attain to Phenice, and there to winter; which is an haven of Crete, and lieth toward the south west and north west.

And when the south wind blew softly, supposing that they had obtained their purpose, loosing thence, they sailed close by Crete.

But not long after there arose against it a tem. pestuous wind, called Euroclydon.

And when the ship was caught, and could not bear up into the wind, we let her drive.

And running under a certain island which is called Clauda, we had much work to come by the boat :

Which when they had taken up, they used helps, undergirding the ship; and, fearing lest they 
should fall into the quicksands, strake sail, and so were driven.

And we being exceedingly tossed with a tempest, the next day they lightened the ship ;

And the third day we cast out with our own hands the tackling of the ship.

And when neither sun nor stars in many days appeared, and no small tempest lay on us, all hope that we should be saved was then taken away.

But after long abstinence Paul stood forth in the midst of them, and said, Sirs, ye should have hearkened unto me, and not have loosed from Crete, and to have gained this harm and loss.

And now I exhort you to be of good cheer: for there shall be no loss of any man's life among you, but of the ship.

For there stood by me this night the angel of God, whose I am, and whom I serve,

Saying, Fear not, Paul ; thou must be brought before Caesar; and, lo, God hath given thee all them that sail with thee.

Wherefore, sirs, be of good cheer : for I believe God, that it shall be even as it was told me.

Howbeit we must be cast upon a certain island.

But when the fourteenth niglit was come, as we were driven up and down in Adria, about midnight the shipmen deemed that they drew near to soine country;

And sounded, and found it twenty fathoms: and 
when they had gone a little further, they sounded again, and found it fifteen fathoms.

Then fearing lest we should have fallen upon rocks, they cast four anchors out of the stern, and wished for the day.

And as the shipmen were about to flee out of the ship, when they had let down the boat into the sea, under colour as though they would have cast anchors out of the foreship,

Paul said to the centurion and the soldiers, Except these abide in the ship, ye cannot be saved.

Then the soldiers cut off the ropes of the boat, and let her fall off.

And while the day was coming on, Paul besought them all to take meat, saying, This day is the fourteenth day that ye have tarried and continued fasting, having taken nothing.

Wherefore I pray you to take some meat: for this is for your health : for there shall not an hair fall from the head of any of you.

And when he had thus spoken, he took bread, and gave thanks to God in presence of them all : and when he had broken it, he began to eat.

Then were they all of good cheer, and they also took some meat.

And we were in all in the ship two hundred threescore and sixteen souls.

And when they had eaten enough, they lightened the ship, and cast out the wheat into the sea. 
And when it was day, they knew not the land: but they discovered a certain creek with a shore, into the which they were minded, if it were possible, to thrust in the ship.

And when they had taken up the anchors, they committed themselves unto the sea, and loosed the rudder bands, and hoisted up the mainsail to the wind, and made toward shore.

And falling into a place where two seas met, they ran the ship aground; and the forepart stuck fast, and remained unmoveable, but the hinder part was broken with the violence of the waves.

And the soldiers' counsel was to kill the prisoners, lest any of them should swim out, and escape.

But the centurion, willing to save Paul, kept them from their purpose; and commanded that they which could swim should cast themselves first into the sea and get to land:

And the rest, some on boards, and some on broken pieces of the ship. And so it came to pass, that they escaped all safe to land. 
The Voyage of Ulysses

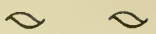

(From the Odyssey; trans.)

BUT when we had now left the island, nor did any other land appear, but the heaven and the sea, then the son of Saturn reared an azure cloud above the hollow ship; and the sea became dark beneath it. But it ran for no very long time; for immediately came the clamouring West wind, rushing with a mighty tempest : and the storm of the wind broke both the cables of the mast; and the mast fell backwards, and all the tackle was thrown in confusion into the hold; and he struck the head of the helmsman backward in the ship, and broke all the bones of his head together; and he fell like unto a diver from the deck, and his noble mind left his bones; and Jove thundered together, and hurled a thunderbolt upon the ship: and it was entirely whirled round, stricken with the thunderbolt of Jove, and it was filled with sulphur; and my companions fell from the ship. And they, like unto gulls, were borne on the waves around the black ship; for the deity took away their return. But I kept going about through the ship, until the storm loosed the sides from the keel; and the wave bore it along naked. And it broke out the mast at the keel: but a thong was thrown upon it, made from the skin of an ox. With this I bound both together, the keel and the mast : and, 
sitting upon them, I was borne by the destructive winds.

Then indeed the West wind ceased raging with a storm, and quickly the South wind came on, bringing grief to my mind, that I should again measure my way to destructive Charybdis. I was borne along during the whole night; and together with the rising sun I came to the rock of Scylla and terrible Charybdis. She gulped up the briny water of the sea; but I, raised on high to the lofty fig-tree, held clinging to it, as a bat, nor could I anywhere either fix myself firmly with my feet, or ascend: for the roots were far off, and the branches were wide apart, and both long and vast, and they overshadowed Charybdis. But I held without ceasing, until she vomited out again the mast and keel; and it came late to me wishing for it: as late as a man has risen from the forum to go to supper, adjudging many contests of disputing youths, so late these planks appeared from Charybdis. And I put down my fcet, and my hands over them, to be carricel along, and I fell with a noise in the middle on the long planks, and sitting upon them, I rowed with my hands. . . .

Thus speaking, divine Ulysses went over the threshold; but with him the strength of Alcinous sent forward a herald, to conduct him to the swift ship and the shore of the sea. Ancl Arete sent women servants with him; one having a well- 
washed robe, and garment, and another she sent with him to carry a heavy coffer: and another carried both bread and red wine. But when they came to the ship and the sea, his illustrious conductors immediately receiving the things, placed them in the hollow ship, all the drink and meat: and then they strewed a rug and linen for Ulysses, on the deck of the hollow ship, that he might sleep without waking, at the stern; but he himself embarked and laid down in silence; and each of them sat on the benches in order; and they loosed the cable from the perforated stone; there they, reclining, threw up the sea with the oar, and sweet sleep fell upon his eyelids, unwakeful, most pleasant, the nearest like death. But it, like as fouryoked male horses in the plain, all incited together by the blows of the scourge, lifting themselves on high, swiftly pass over the way; so its prow indeed lifted itself up, and the mighty purple billow of the much-rolling sea rushed behind. And very safely it ran, steadily; nor could a falcon-hawk, swiftest of birds, have followed it close. So it, running swiftly, cut the waves of the sea, bearing a man who possessed counsels equal to the gods: who before had suffered very many griefs in his mind, both wars of men, and passing the terrible waves: then indeed he slept fearlessly, forgetting whatever things he had suffered. 
When a very shining star arose, which especially comes announcing the light of the morning, the mother of day; at that time then the ship that passes over the sea neared the island.

Now there is a certain haven of Phorcys, the old man of the sea, amongst the people of Ithaca ; and there are two abrupt projecting shores in it, inclining towards the port, which swell from the great wave of hard blowing winds from without; but within well-benched ships remain without a chain, when they reach the goal of the mooringstation. . .

There they drove in, being before acquainted with it; it indeed ran ashore more than half its length, hastening; for by the hands of such rowers was it urged on. And they, disembarking from the well-yoked ship to the shore, first lifted Ulysses out of the hollow ship, with his very linen and beautiful rug, and placed him, overcome with sleep, on the sand. . . .

Thus having spoken, he received from him his brazen spear, and extended it on the deck of the ship rowed on both sides; and he himself $\mathrm{cm}$ barked in the sea-traversing ship. And then he sat down in the stern; and he scated Theoclymenus near himsclf: and they (the sailors) loosed the halsers. And Telemachus, exhorting his companions, bade them make ready the tackle; and they eagerly obcyed. And, raising the pine mast, 
they placed it within the hollow mast hole, and bound it down with cables; and they hoisted the white sails with well-twisted bull-hides. And to them blue-eyed Minerva sent a favourable gale, blowing sharply upon them through the air, that the ship, running along, might very quickly make its way over the briny water of the sea. And they came to Crouni and to fair-streamed Chalcis. But the sun set, and all the ways were overshadowed. And it reached Phere, driven on by a favourable gale from Jove; and to divine Elis, where the Epeans rule. From thence he sent it on to the swift islands, meditating whether he should escape death or be taken.

Homer.

Counsel for Mariners
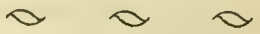

(From The Works and Day's; trans.)

PRAISE a small vessel, but put your cargo in a large one. ... For fifty days after the summer solstice, when the summer season of labour is past, sailing is seasonable for men: neither would you wreck your ship, nor would the sea drown the crew, unless of design Neptune, who shakes the earth, or Jupiter, king of the Gods, should choose to destroy them; for these decide the end of good folk and of bad. But at that season the winds 
blow steady, the sea is safe; then you are safe to trust the winds and drag down your swift ship to the water's edge and put the cargo on board. . . . Another good time for sailing is in the spring. . . . I praise not the spring voyage, for it must be performed in haste... But death in the waves is fearful. . . Do not put all your belongings in hollow ships, but leave the bulk behind and take the smaller portion as cargo.

Hesiod.

The Dawn of Navigation

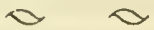

(From The Nalure of Things; trans.)

NOR did the boisterous floods of the sea in 1 those times dash ships and men on the rocks. The ocean, often rising and swelling, as it does today, stormed in vain and to no purpose, and laid aside its empty threats without effect; nor could the deceitful allurement of its calm water entice with its smiling waves anyone into danger; for the daring art of navigation was then unknown. . The sea was next covered with ships for the sake of perfumes.

Lucretius. 
Shipwreck
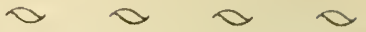

(From the AEneid; trans.)

THUS having said, whirling the point of his spear, he struck the hollow mountain's side and the winds, as in a formed battalion, rush forth at every vent, and scour over the lands in a hurricane. They press upon the ocean, and at once, east, and south, and stormy south-west, plough up the whole deep from its lowest bottom, and roll vast billows to the shores. The cries of the seamen succeed, and the cracking of the cordage. In an instant clouds snatch the heavens and day from the eyes of the Trojans: sable night sits brooding on the sea, thunder rolls from pole to pole, the sky glares with repeated flashes, and all nature threatens then with immediate death. . . .

A tempest, roaring from the north, strikes across the sail, and heaves the billows to the stars. The oars are shattered : then the prow turns away, and exposes the side to the waves. A steep mountain of waters follows in a heap. These hang on the towering surge; to those the wide-yawning deep discloses the earth between two waves: the whirling tide rages with mingled sand. Three other ships the south wind, hurrying away, throws on hidden rocks; rocks in the midst of the ocean, which the Italians call Altars, a vast ridge rising to the surface of the sea. Three from the deep 
the east wind drives on shoals and flats, a piteous spectacle! and dashing on the shelves, it encloses them with mounds of sand. Before the eyes of Eneas himself, a mighty billow, falling from the height, dashes against the stern of one which bore the Lycian crew, and faithful Orontes, the pilot, is tossed out and rolled headlong, prone into the waves; but her the driving surge thrice whirls around in the same place, and the rapid eddy swallows up in the deep.

Then, floating here and there on the vast abyss, are seen inen, their arms and planks, and the Trojan wealth among the waves. Now the storm overpowered the stout vessel of Ilioneus, now that of brave Achates, and that in which Abas sailed, and that in which old Alethes: all, at their loosened and disjointed sides, receive the hostile stream, and gape with chinks. . . .

The sire, having by these words soothed and cheered the heart of the goddess, yokes his steeds to his grolden car, puts the foaming bit into their fierce mouths, and throws out all the reins. Along the surface of the seas he nimbly glicles in his azure car. The waves subside, and the swelling ocean smooths its liquid pavement under the thundering axle: the clouds fly off the face of the expanded sky. Then appear the various forms of his retinue, unwieldy whales, and the aged train 
of Glaucus, and Palemon, Ino's son, the swift Tritons, and the whole band of Phorcus. On the left are Thetis, Melite, and the virgin Panopa, Nesæe, Spio, Thalia, and Cymodoce. Upon this, soft joys in their turn diffuse themselves through the anxious soul of father Aneas. Forthwith he orders all the masts to be set up, and the yards to be stretched along the sails. At once they all tacked together, and together let go sometimes the left-hand sheets, sometimes the right : at once they turn and turn back the lofty end of the sailyards: friendly gales waft the fleet forward. Palinurus, the master-pilot, led the closely-united squadron: towards him the rest were ordered to steer their course.

And now the dewy night had almost reached the middle of her course; the weary sailors, stretched along the hard benches under the oars, relaxed their limbs in peaceful repose; when the god of sleep, gliding down from the ethereal stars, parted the dusky air, and dispelled the shades; to you, O Palinurus, directing his course, visiting you, though innocent, with dismal dreams: and the god took his seat on the lofty stern, in the similitude of Phorbas, and poured forth these words from his lips: Palinurus, son of Iasïus, the seas themselves carry forward the fleet; the gales blow fair and steady, the hour for rest is given. Recline your liead, and steal your weary eyes from 
labour. Myself awhile will discharge your duty. To whom Palinurus, with difficulty lifting up his eyes, answers: Do you then bid me be a stranger to the aspect of the calm sea and its quiet waves? Shall I confide in this extraordinary apparition? Why should I trust Æneas to the mercy of the fallacious winds, after having been so often deceived by the treacherous aspect of a serene sky? These words he uttered, while, fixed and clinging, he did not part with the rudder, and held his eyes directed to the stars; when, lo! the god shakes over both his temples a brancl drenched in the dew of Lethe, and impregnated with soporofic Stygian influence; and, while he is struggling against sleep, dissolves his swimming eyes. Scarcely had unexpected slumber begun to relax his limbs, when the god, leaning on him with part of the stern broke off, plunged him headlong into the limpid waves, often calling on his friends in vain: taking flight, raised himself on his wings aloft into the air. Meanwhile, the fleet runs its watery course on the plain with equal security, and, fearless, is conducted by father Neptune's promises. And now, wafted forward, it was even coming up to the rocks of the Sirens, once difficult of access, and white with the bones of many (at that time the hoarse rocks resounded far with the continual buffeting of the briny waves); when father Eneas perceived the fluctuating galley to 
reel, having lost its pilot; and he himself steered her through the darkened waves, deeply affected and wounded in his soul for the misfortune of his friend. Ah, Palinurus, who hast too much confided in the fair aspect of the skies and sea! naked wilt thou lie on unknown sands!

Virgil.
A Stormy Voyage
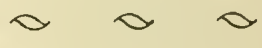
(From the Tristia; trans.)

$\mathrm{A}^{\mathrm{H} \text {, wretched me! What mountains of water }}$ are heaped aloft! You would think that this very instant they would reach the highest stars. What abysses yawn as the sea recedes! You would suppose that this very instant they would extend to black Tartarus. On whichever side you look, there is nothing but sea and sky; the one swelling with billows, the other lowering with clouds. Between the two the winds rage in fearul hurricane. The waves of the ocean know not which master to obey. For at one moment Eurus gathers strength from the glowing east, at another instant comes Zephyrus, sent from the evening west. At one time the icy Boreas comes ranging from the dry north; at another, the south wind wages battle with adverse front. The steersman is at fault: and he knows not what to avoid, or 
what course to take. Skill itself is at a loss amid these multiplied evils.

In truth, we are on the verge of destruction, and there is no hope of safety, but a fallacious one; as I speak, the sea dashes o'er my face. The waves will overwhelm this breath of mine, and in my throat, as it utters vain entreaties, shall I receive the waters that are to bring my doom.

But meantime my affectionate wife is bewailing nothing else but that I am an exile; this one portion alone of my misery does she know and lament. She is not aware how my body is tossed on the boundless ocean; she knows not that I am driven to and fro by the winds; she knows not that death is impending o'er me. 'Tis well, ye Gods, that I suffered her not to embark with me: so that death might not have to be twice endured by wretched me! But now, although I perish, since she is safe from danger, doubtless I shall still survive in her one half of myself.

Ah, wretched me! how the clouds glisten with the instantancous flash. How dreadful the peal that re-echoes from the sky of heaven. The timbers of our sides are struck by the waves, with blows no lighter than when the tremendous charge of the balista beats against the walls. The wave that now is coming on o'ertops all the others; 'tis the one that comes after the ninth and before the eleventh. 
I fear not death; 'tis the dreadful kind of death; take away the shipwreck; then death will be a gain to me. 'Tis something for one, either dying a natural death or by the sword, to lay his breathless corpse in the firm ground, and to impart his wishes to his kindred, and to hope for a sepulchre, and not to be food for the fishes of the sea. . .

The guardian of the Erymanthian Bear is immersed in the ocean, and by the influence of her Constellation arouses the waves, while I am ploughing the Ionian Sea by no inclination of my own; but apprehension itself forces me to be bold. Ah, wretched me! by how tremendous a gale is the sea aroused, and how the sand seethes again as it is ploughed up from the lowest depths. The waves, no lower than a mountain, are hurled over the prow and the curving poop, and dash against the resemblances of the Deities. The pinewood texture creaks ; the rigging, with loud noise, is beaten to and fro; and the very ship groans responsively to my woes. The sailor, betraying his fear by the paleness of an ice-cold chill, now passively follows his bark o'ercome by the storm, and guides it not by his skill. Just as the driver, failing in his strength, loosens the useless reins on a horse of unbending neck, so do I behold our charioteer set the sails of the ship, not in the direction that he desires, but whither the raging 
current of the sea is driving us; and unless Eolus sends breezes from another quarter, I shall be carried to lands now forbidden to be approached by me. For, Illyria being descried afar to the left, the forbidden shores of Italy are beheld by me. May the wind, I pray, cease to blow towards the forbidden regions, and together with me, may it obey the great Deity. While I am speaking, and am, at the same moment, both longing and fearing to be hurried back again, with what tremendous force does the wave lash upon our sides! Spare me, ye Deities of the azure ocean, spare me; let it be enough that Jove is incensed with me: save my wearied life from a cruel death, if, indeed, one who is already undone can possibly be sayed from perishing.

Ovid.

For the Fisherman
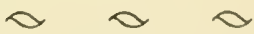

(From the IIalieuticon; trans.)

BUT I would not recommend you to go out into the midst of the ocean, nor to try the depths of the open sea. You will do better to regulate your cable according to each kind of locality. At one time, the spot may be rugged with rocks; such demands the pliant fishing-rods whereas the smooth shore requires the net. Does some lofty mountain send its deepening shadows 
over the sea, according to their different natures, some fish avoid, and some seek, such a spot. If the sea is green from the weeds that grow at the bottom ... let him apply patience, and let him watch by the soft seaweed. Nature has designed, in a varied manner, the botton of the ocean, and she has not willed that all fish should frequent the same haunts; for there are some that love the open sea, such as the mackerel, and the sea-ox, and the darting hippurus, and the gurnet with its swarthy back, and the valuable helops, unknown in our waters, and the hardy sword-fish, not less dangerous than a sword with its blow, and the timid tunnies that fly in large shoals. . . .

Ovid. 
II

CHARACTER OF THE SEA 
I cannot see the heavings of this prodigious bulk of waters, even in a calm, without a very pleasing astonishment; but when it is worked up in a tempest, so that the horizon on every side is nothing but foaming billows and floating mountains, it is impossible to describe the agreeable horror that rises from such a prospect. A troubled ocean, to a man who sails upon it, is, I think, the biggest object that he can see in motion, and, consequently, gives his inagination one of the higliest kinds of pleasure that can arise from greatness.

Joseph Addison (from The Spectator). 


\section{The Disturber}
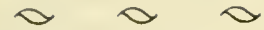

(From The Sands of Pleasure)

THE sea is the great disturber. Nothing 1 human can endure for long unchanged in its presence; no work of man's hands, or of his thoughts, or even of his character and qualities, but must ultimately go down before its eternal force; nothing of himself, flesh or spirit, but must thrill and change with the pulses of its unquiet heart. Its vastness is confounding, and towers over us, dwindling us to pin-points of unimportance; beside its movements, calm and punctual, laid out in cycles of the everlasting, the most majestic of our actions seem as petty as the fretting trill of an insect's wing; its storms hush our wars and revolutions; our deepest silences are audible in its profound calms; and within its age the twinkling moments of our life pass and disappear unheeded into the murk of eternity.

liilson Young. 
The Unsympathetic
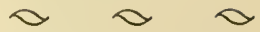

(From Ireland at the Cross Roads)

$A N D$ so to-day the Irish who dwell within $A$ journey of these wild shores retain in their nature the dislike and terror of the sea. Its mists relax their energies, it fills them with a sense of something always greater than themselves that can bring their efforts to instant and disastrous confusion. While they inhabit these shores, though they build boats and cast nets and go abroad in a timid search for the sea's treasures, they can have nothing in common with it but the refiection of its bright shining in their eyes, and the movements of its unquiet heart in their blood.

The sea, indeed, does little for Ireland. Into the stately waterways of Cork, of Galway, of Limerick, the tide twice a day comes brimming up, filling with its inexhaustible flood the spaces between the imposing, empty warehouses. But its majestic invitation goes unheeded; the beautiful buildings, raised when Ireland had a population and a trade, are crumbling and deserted; great chambers that once resounded with the inspiring clamour of business, know it no longer; and where formerly the stevedores sweated, carts rattled, and merchants made their exchanges, little barefoot children now play undisturbed in the sun- 
shine. These western ports were nobly furnished by nature and by man for the accommodation of shipping, but the ships pass them by far out at sea. They just exist, derclict and half ruinous, unvisited save by the punctual tides.

And along a coast, unmatched in the world for its bay's and inlets and roadsteads, you may note blight and desolation marking the sea's revenges. Denied its toll of commerce and ocean-going ships, it swecps round the coast from Donegal to Cork, savagely withholding support and livelihood. To look at the map one might think there was not a mile along the western coast of Ireland where a boat could not be launched; but as a matter of fact, places where the business of fishing can be carried on are but few and far between. The bays are there, and the deep water roadsteads; but the little breakwaters and harbours in the shelter of which small boats might be kept, are missing - there is no money to build them. The great Atlantic surges come smashing in from their thousand miles journeys, unchecked by any artifice of man, and where they throw their weight on the shore no boats can profitably be kept. . . .

. And if at the fall of some summer evening you walk along a mile of these lonely shores, you may almost believe you are the last man alive on the earth. The country untilled, ungrazed, rolls upon every side upwards to the clouds. There is 
not a sign of man or of beast; not even the bark of a dog, that wholesome signal of human occupation, falls on your ear. The world seems like a house from which the inhabitants have gone out and locked the door behind them, and left you to look in through the windows at the empty rooms. The silence is broken only by the crying of the gulls and by the lap of the waves on the shore. They come marching in from the sunset line from the cold, restless desert of the ocean, reminding the solitary watcher of the one ultimate solution of all human problems. For the ocean is the one great living thing in all this solitary prospect, the thing that was from the beginning and will always be ; it alone, with its wrinkled inscrutable face and mysterious respirations, is an earnest of the things that go on. What wonder if the peasant, standing amid the ruin of human industry on its margin, should regard it as the separating barrier between him and the world? Enemy and avenger though it be, the track of the sunset across it seems the one escape from it, the one pathway to hope and the fulfilment of life. What wonder if he also should "long to tread that golden path of rays," and believe that it must indeed lead him to some brighter destiny?

Filson Young. 
The Terrible

(From $A$ Description of Spain ; trans.)

THE ocean encircles the ultimate bounds of the inhabited earth, and all beyond it is unknown. No one has been able to verify anything concerning it, on account of its difficult and perilous navigation, its great obscurity, its profound depth, and frequent tempests, through fear of its mighty fishes, its haughty winds; yet there are many islands in it, some peopled, others not. There is no mariner that dares enter on its deep waters, or those who have done so have merely kept along its coasts, fearful of departing from them. The waves of this ocean, though they roll as high as mountains, yet maintain themselves unbroken, for if they broke, then no ship could plough them.

Edrisi.

\section{The Inert}
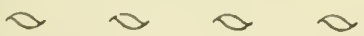

(From Sull'Occano)

I L mare si mostrava quella mattina in uno de 1 suoi aspetti più brutti e più odiosi : immobile sotto una volta bassa di nuvole gonfie e inerti, di colore griallo sporco, d'un'apparenza viscida, come se fosse tutta una leelletta di terra grassa, in cui un rampone da pesca avesse a rimanere confitto come 
una stecca nel mastice; e pareva che non vi dovessero guizzare dei pesci, ma delle bestie deformi e immonde, del suo stesso colore. Un aspetto simile presentano forse le pianure della regione occidentale del Mar Caspio, quando son coperte dalle eruzioni dei vulcani di fango. Se fosse vero che questo immenso mare, salato come il sangue, e dotato d'una circolazione, d'un polso e d'un cuore, non è un elemento inorganico, ma uno smisurato animale vivente e pensante, avrei detto quella mattina ch'egli volgeva in mente $i$ più sconci pensieri, farneticando in uno stato di mezzo assopimento, come un bruto briaco. Ma neanche risvegliava l'idea della vita, poichè non v'era un respiro di vento, e sulla sua faccia non appariva nè una contrazione nè una ruga. Dava l'immagine di quell' angolo d'oceano cleserto, rimasto per molto tempo inesplorato, che si stende fra la corrente di Humboldt e quella che le va incontro dal centro del Pacifico, posto fuori delle grandi vie della navigazione, dove non si vede nè vela, nè balena, nè gavotta, nè alcione; dai confini del quale tutto fugge, ogni indizio di vita dispare; e se il vento - la tempesta vi gettano qualche volta un bastimento smarrito, pare ai navigatori di esser caduti nelle acque d'un mondo morto.

Edmondo de Amicis. 


\section{The Boundless}
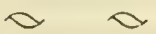

(From Cosmos; trans.)

$A^{L L}$ who possess an ordinary degree of mental activity, and delight to create to themselves an inner world of thought, must be penetrated with the sublime image of the infinite, when, gazing around them on the vast and boundless sea, involuntarily the glance is attracted to the distant horizon where air and water blend together, and the stars continually rise and set before the eyes of the mariner. This contemplation of the eternal play of the elements is clouded, like every human joy, by a touch of sadness and of longing.

\section{Von Humboldt.}

\section{The Excitable}
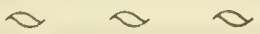

(From A Hislory of S\%. Domingo; trans.)

THE sea of those islands is commonly more tranquil than ours; but, like certain people who are excited with difficulty, and whose transports of passion are as violent as they are rare, so when the sea becomes irritated, it is terrible. It breaks all bounds, overflows the country, sweeps away all things that oppose it, and leaves frightful ravages behind to mark the extent of its inundations. It is after these tempests, known by the 
name of hurricanes, that the shores are covered with marine shells, which greatly compass in lustre and beauty those of the European seas.

\section{P. F. Xavier de Charlevoix.}

The Image of It
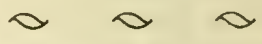

(From The Harbours of England) $\mathrm{UT}$ Turner found during his Southern Coast
tour that the sea was not this: that it was, on the contrary, a very incalculable and unhorizontal thing, setting his "water-mark" sometimes on the highest heavens, as well as on sides of ships ;-very breakable into pieces, half of a wave separable from the other half, and on the instant carriageable miles inland; - not in any wise limiting itself to a state of apparent liquidity, but now striking like a steel gauntlet, and now becoming a cloud and vanishing, no eye could tell whither; one moment a flint cave, the next a marble pillar, the next a mere white fleece, thickening the thundery rain. He never forgot those facts ; never afterwards was able to recover the idea of positive distinction between sea and sky, or sea and land. Steel gauntlet, black rock, white cloud, and men and masts gnashed to pieces and disappearing in a few breaths and splinters among them;-a little blood on the rock angle, like red seaweed, sponged 
away by the next splash of the foam, and the glistening granite and green water all pure again in vacant wrath. So stayed by him, for ever, the Image of the Sea.

John Ruskin.

How to Paint It
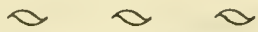

(From MS. Notebooks ; trans.)

IF you wish to represent a tempest properly, consider and set down exactly what are the results when the wind blowing over the face of the sea and of the land lifts and carries with it every thing that is not immovable in the general mass. . . . Let the sea be wild and tempestuous, and between the crests of its waves it should be covered with eddying foam, and the wind should carry the finer spray through the stormy air after the manner of a thick and all-enveloping mist. Of the ships that are there, some you should show with sail rent and the shreds of it flapping in the air in company with the broken lalyards, and some of the masts broken and gone by the board, and the vessel itself lying disabled and broken by the fury of the waves, with some of the crew shrieking and clinging to the fragments of the wreck. You should show the clouds, driven by the impetuous winds, hurled against the high mountain tops, and there wreathing and eddying 
like waves that beat upon the rocks; the very air should strike terror through the murky darkness occasioned therein by the dust and mist and thick clouds.

Leonardo da Vinci.

The Cunning
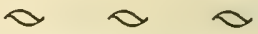

(From Les Travailleurs de la Mer)

D'ORDINAIRE la mer cache ses coups. Elle reste volontiers obscure. Cette ombre in. commensurable garde tout pour elle. Il est très rare que le mystère renonce au secret. Certes, il y a du monstre dans la catastrophe, mais en quantité inconnue. La mer est patente et secrète; elle se dérobe, elle ne tient pas à divulguer ses actions. Elle fait un naufrage, et le recouvre; l'engloutissement est sa pudeur. La vague est hypocrite; elle tue, recèle, ignore et sourit. Elle rugit, puis moutonne.

Victor Hugo.

The Malicious
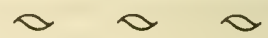

(From The MFirror of the Sea)

A LREADY I looked with other eyes upon the A sea. I knew it capable of betraying the generous ardour of youth as implacably as, indifferent to evil and good, it would have betrayed 
the basest greed or the noblest heroism. My conception of its magnanimous greatness was gone. And I looked upon the true sea-the sea that plays with men till their hearts are broken, and wears stout ships to death. Nothing can touch the brooding bitterness of its heart. Open to all and faithful to none, it exercises its fascination for the undoing of the best. To love it is not well. It knows no bond of plighted troth, no fidelity to misfortune, to long companionship, to long devotion. The promise it holds out perpetually is very great ; but the only secret of its possession is strength, strength $\rightarrow$ the jealous, sleepless strength of a man guarding a coveted treasure within his gates.

Joseph Conrad.

\section{The Opaque}
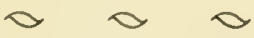

(From At Last)

VERY remarkable, meanwhile, and unexpected, was the opacity and seeming solidity of the ocean when looked down on from the bows. Whether sapphire under the sunlight, or all but black under the clouds, or laced and streaked with beads of foam, rising out of the nether darkness, it looks as if it could resist the hand; as if one might almost walk on it; so unlike any liquid, as seen 
near shore or inland, is this leaping, heaving plain, reminding one, by its innumerable conchoidal curves, not of water, not even of ice, but rather of obsidian.

Churles Kingsley. 
III

SCENERY 
Cape Cod is the bared and bended arm of Massachusetts: the shoulder is at Buzzard's Bay; the elbow, or crazy-bone, at Cape Mallebarre; the wrist at Truro; and the sandy fist at Provincetown,-behind which the State stands on her guard, with her back to the Green Mountains, and her feet planted on the floor of the ocean, like an athlete protecting her Bay,-boxing with northeast storms, and, ever and anon, heaving up her Atlantic adversary from the lap of earth, - ready to thrust forward her other fist, which keeps guard tlie while upon her breast at Cape Ann.

H. D. Thoreau. 
Perspective of the Cliffs

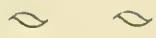

(From The Sfirit of Place)

$\mathrm{I}^{\mathrm{T}}$ is the law whereby the eye and the horizon answer one another that makes the way up a hill so full of universal movement. All the landscape is on pilgrimage. The town gathers itself closer, and its inner harbours literally come to light; the headlands repeat themselves; little cups within the treeless hills open and show their farms. In the sea are many regions. A breeze is at play for a mile or two, and the surface is turned. There are roads and curves in the blue and in the white. Not a step of your journey up the height that has not its replies in the steady motion of land and sea. Things rise together like a flock of manyfeathered birds. . . .

... Up at the top of the scaward hill your first thought is one of some compassion for sailors, inasmuch as they see but little of their sea. A child on a mere Channel cliff looks upon spaces and sizes that they cannot see in the I'acific, on the ocean side of the world. Never in the solitude of the blue water, never between the Cape of Good Hope and Cape Horn, never between the Islands and the West, has the seaman seen anything but a little circle of sea. The Ancient Mariner, when he 
was alone, did but drift through a thousand narrow solitudes. The sailor has nothing but his mast, indeed. And but for his mast he would be isolated in as small a world as that of a traveller through the plains.

Round the plains the horizon lies with folded wings. It keeps them so perpetually for man, and opens them only for the bird, replying to flight with flight.

A close circlet of waves is the sailor's famous offing. His offing hardly deserves the name of horizon. To hear him you might think something of his offing, but you do not so when you sit down in the centre of it.

As the upspringing of all things at your going up the heights, so steady, so swift, is the subsidence at your descent. The further sea lies away, hill folds down behind hill. The whole upstanding world, with its looks serene and alert, its distant replies, its signals of many miles, its signs and communications of light, gathers down and pauses. This flock of birds, which is the mobile landscape, wheels and goes to earth. The Cardinal weighs down the audience with his downward hands. Farewell to the most delicate horizon.

Alice Meynell. 
The Cliffs of Devon

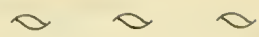

(From My Devon Year)

$\mathrm{NO}$ county is richer in splendour of great precipices looking out upon broad and narrow seas than this our Devon; but though the southern cliffs lack that awful austerity and abiding gloom of the northern crags, though their pinnacles and serrated edges and escarpments are but pigmies in altitude when compared with the huge foreheads that frown upon the Atlantic from Welcombe to the Foreland, yet Nature has compensated their shortcomings of size, and bestowed upon them a beauty and an infinite variety of colour and form not met with where the great ocean waves break and thunder at their journey's end. There, even though the sea has slept for many summer days, and sinks and rises with peace as profound and suggestive as the slumber of a giant, the accustomed striving and unrest are reflected in the dark precipices above it, in the tremendous acclivities and the prevalent geological formation of huge and gloomy planes that suck up direct sunshine, as a sponge soaks liquid, and are nothing brightened. They stare, these hugre clifffaces, with blind eyes into the West ; they call for sad human hearts to chime with their sobriety; they breathe of ceiseless war, of agonized battle with the West wind and all its unnumbered hosts 
of the sea. Setting sunlight gilds their slaty shale, and brightens it into polished ebony and into gold; they frown at the evening light until its glory dies and the foam-ridges glimmer grey; then familiar darkness huddles down upon them, and they wait alert, watchful, for the first sigh of the awakened enemy, the first throb and spout of some giant wave at their feet. These cliffs impress some spirits with aversion, yet from others they win such sympathy in their struggle as Prometheus himself won, but seldom the scorched and blasted crags of Caucasus that made his pillow. ... .

There came now a growing growl from the waters, and here and there, against some solitary seaward rock, a sheaf of silver feathers shone upwards, then fell with a sigh to fret the wave that brought it. The tide came in again, and as it returned, sweeping the ledges one by one, lifting their shaggy weeds, pouring pure sea into each pool, sliding nearer and nearer with gentle, hogbacked waves that hid their strength, I passed before it and retreated by cliff-ways where the honeysuckle, the golden-rod, and the burnet-rose flourished together aloft, and made no quarrel with the wind that dwarfed and stunted them and robbed them of adult shape.

Eden Phillpotts. 
The Cliffs of Scotland

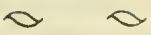

(From The Pirate)

I $\mathrm{N}$ front lay the sea, into which two headlands, 1 which formed the extremities of the bay, projected their gigantic causeways of dark and sable rocks, on the ledges of which the gulls, scouries, and other sea-fowl appeared like flakes of snow ; while, upon the lower ranges of the cliff, stood whole lines of cormorants, drawn up alongside of each other, like soldiers in their battle array, and other living thing was there none to see. The sea, although not in a tempestuous state, was disturbed enough to rush on thesc capes with a sound like distant thunder, and the billows, which rose in sheets of foam half-way up these sable rocks, formed a contrast of colouring equally striking and awful.

Betwixt the extremities, or capes, of these projecting headlands there rolled, on the day when Mertoun visited the scene, a deep and dense aggregation of clouds, through which no human eye could penetrate, and which, bounding the vision, and excluding all view of the distant ocean, rendered it no unapt representation of the sea in the Vision of Mirza, whose extent was concealed by vapours, and clouds, and storms. The ground, rising steeply from the sea-beach, permitting no view into the interior of the country, appeared 
scene of irretrievable barrenness, where scrubby and stunted heath, intermixed with the long bent or coarse grass, which first covers sandy soils, were the only vegetables that could be seen.

Sir Walter Scott.

\section{An Essex Sea-Marsh}
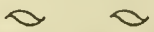

(From Mehalah)

$B^{E T W E E N ~ t h e ~ m o u t h s ~ o f ~ t h e ~ B l a c k w a t e r ~ a n d ~}$ the Colne, on the east coast of Essex, lies an extensive marshy tract veined and freckled in every part with water. It is a wide waste of debatable ground contested by sea and land, subject to incessant incursions from the former, but stubbornly maintained by the latter. At high tide the appearance is that of a vast surface of moss or Sargasso weed floating on the sea, with rents and patches of shining water traversing and dappling it in all directions. The creeks, some of considerable length and breadth, extend many miles inland, and are arteries whence branches out a fibrous tissue of smaller channels, flushed with water twice in the twenty-four hours. At noontides, and especially at the equinoxes, the sea asserts it royalty over this vast region, and overflows the whole, leaving standing out of the flood only the long island of Mersea, and the lesser 
islet, called the Ray. This latter is a hill of gravel rising from the heart of the Marshes, crowned with ancient thorn trees, and possessing, what is denied the mainland, an unfailing spring of purest water. At ebb, the Ray can only be reached from the old Roman causeway, called the Strood, over which runs the road from Colchester to Mersea Isle, connecting formerly the city of the Trinobantes with the station of the count of the Saxon shore. But even at cbb, the Ray is not approachable by land unless the sun or east wind has parched the ooze into brick; and then the way is long, tedious and tortuous, among bitter pools and over shining creeks. It was perhaps because this ridge of high ground was so inaccessible, so well protected by nature, that the ancient inhabitants had erected on it a rath, or fortified camp of wooden logs, which left its name to the place long after the timber defences had rotted away.

A more desolate region can scarce be conceived, and yet it is not without beauty. In summer, the thrift mantles the marshes with shot satin, passing through all gradations of tint from maiden's blush to lily white. Thereafter a purple glow steals over the waste, as the sea lavender bursts into flower, and simultancously every creck and pool is royally fringed with sea aster. A little later the glasswort, that shot up green and transparent as 
emerald glass in the early spring, turns to every tinge of carmine.

Rev. S. Buring-Gould.

\section{A Sea Cavern}
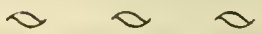

(From Malcolm)

$\mathrm{HE}^{\mathrm{E}}$ had forgotten how beautiful it was, and stood amazed at the richness of its colour, imagining he had come upon a cave of the serpentine marble which is found on the coast ; for sides and roof and rugged floor were gorgeous with bands and spots and veins of green and rusty red. A nearer inspection, however, showed that these hues were not of the rock itself, but belonged to the garden of the ocean; and when he turned to face the sea, lo! they had all but vanished, the cave shone silvery grey, with a faint moving sparkle, and out came the lovely carving of the rodent waves. All about, its sides were fretted in exquisite curves, and fantastic yet ever graceful knots and twists; as if a mass of gnarled and contorted roots, first washed of every roughness by some ethereal solvent, leaving only the soft lines of yet grotesque volutions, had been transformed into mingled silver and stone. 
IV

NIGHT AND DAY 
Most weird and fantastic are these nightly visits to West Indian harbours. Above, the black mountain-depths, with their canopy of cloud, bright white against the purple night, hung with keen stars. The moon, it may be on her back in the west, sinking like a golden goblet behind some rock-fort, half shrouded in black trees. Below, a line of bright mist over a swamp, with the cocopalms standing up through it, dark, and yet glistering in the moon. . . . The echo of the gun from hill to hill. WVild voices from shore and sca. The snorting of the steamer, the rattling of the chain through the hawse-hole; and on deck, and under the quarter, strange gleams of red light amid pitchy darkness, from engines, galley fires, lanthorns; and black folk and white folk flitting restlessly across them.

Charles Kingsley (from At Last). 
Night on a Steamer

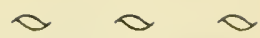

(From Essays of Traziel)

I $T$ was a bleak and uncomfortable day; but at night, by six bells, although the wind had not yet moderated, the clouds were all wrecked and blown away behind the rim of the horizon, and the stars came out thickly overhead. I saw Venus burning as steadily and sweetly across this hurlyburly of the winds and waters as ever at home upon the summer woods. The engine pounded, the screw tossed out of the water with a roar, and shook the ship from end to end; the bows battled with loud reports against the billows; and as I stood in the lec-scuppers and looked up to where the funnel leaned out, over my head, vomiting smoke, and the black and monstrous topsails blotted, at each lurch, a different crop of stars, it seemed as if all this trouble were a thing of small account, and that just above the mast reigned peace unbroken and etermal.

R. I. Stevenson. 
Night in a Cornish Port

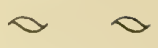

(From Lying Prophets)

UNDER moonlight, the returning luggers crept homewards, like inky silhouettes on a background of dull silver. Every moment added to the forest of masts anchored at the moorings outside the harbour; every minute another ridinglight glimmered and another rowing-boat shot between the granite piers, to slide silently within the darkness under shore, as it left moonlit rings widening out behind at each dip of the oars. Joan sat down under the lighthouse and waited in the stillness for her father's boat. Yellow flashes, like fireflies, twinkled along through Newlyn, and above them the moon brought out square patches of silver-bright roof, seen through a blue night. Now and then a bell rang in the harbour, and lights leapt here and there mingling red snakes and streamers of fire with the white noonbeams where they lay on still water. Then Joan knew the fish were being sold by auction, and she grew anxious for her father's return, fearing that prices might have fallen before he arrived. Great periods of silence lay between the ringings of the bell, and at such times faint laughter and voices foated out from shore, blocks chipped and rattled as sails came down, a concertina squeaked fitfully where it was played on a Norwegian ice-boat at the 
harbour quay. The tide was coming in, and Joan watched many lights reflected in the harbour, and wondered why the gold of them contrasted so ill with the silver from the moon.

Eden Phillpotts.

Night on the Mediterranean

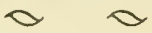

(From Voyage cn Oricut')

A U-DESSUS du corps sombre du bâtiment, le nuage de toutes ses voiles était groupé pittoresquement et pyramidait autour de ses mâts. Elles s'élevaient d'étages en étagres, de vergues en vergues, découpées en mille formes bizarres, déroulécs en plis larges et profonds, semblables aux nombreuses et hautes tourelles d'un château gothique groupées autour du donjon; elles n'avaient ni le mouvement ni la couleur éclatante et dorée des voiles vues de loin sur les flots pendant le jour ; immobiles, ternes et teintes par la nuit d'un gris ardoisé, on eût dit une volée de chauves-souris immenses, ou d'oiseaux inconnus des mers, abattus, pressés, serrés les uns contre les autres sur un arbre gigantesque, et suspendus à son tronc dépouillé, au clair de lune d'une nuit d'hiver. L'ombre de ce nuage de voiles descendait d'en haut sur nous et nous dérobait la moitić de l'horizon. Jamais plus colossale et plus étrange vision de la mer n'apparut à l'esprit 
d'Ossian dans un songe. Toute la poesie des flots était là. La ligne bleue de l'horizon se confondait avec celle du ciel; tout ce qui reposait dessus et dessous avait l'apparence d'un seul fluide éthéré dans lequel nous nagions. Tout ce vague sans corps et sans limites augmentait l'effet de cette apparition gigantesque de la frégate sur les flots, et jetait l'âme avec l'œil dans la même illusion. Il me semblait que la frégate, la pyramide aérienne de sa voilure et nous-mêmes, nous étions tous ensemble soulevés, emportés, comme des corps célestes dans les abîmes liquides de l'éther, ne portant sur rien, planant par une force intérieure sur le vide azure d'un universel firmament.

\section{Alphonse Marie Louis Lamartine.}

Dawn on the Iceland Banks

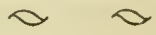

(From Pếchcur d'Islande) LS avaient tous veillé la nuit d'avant et attrapé,
en trente heures, plus de nille morues très grosses; aussi leurs bras forts étaient las, et ils s'endormaient. Leurs corps veillait seul, et continuait de lui-même sa manœuvre de pêche, tandis que, par instants, leur esprit flottait en plein sommeil. Mais cet air du large qu'ils respiraient était vierge comme aux premiers jours du mond, et si vivifiant que, malgré leur fatigue, ils se sentaient 
la poitrine dilatée et les joues fraîches. La lumière matinale, la lumière vraie, avait fini par venir; comme au temps de la Genèse elle s'était separée d'avec les ténèbres qui semblaient s'être tassées sur l'horizon, et restaient là en masses très lourdes; en y voyant si clair on s'apercevait bien à present qu'on sortait de la nuit,-que cette lueur d'avant avait été vague et étrange comme celle des rêves.

Dans ce ciel très couvert, très épais, il y avait çà et là des déchirures, comme des percées dans un dôme, par où arrivaient de grands rayons couleur d'argent rose. Les nuages inferieurs étaient disposés en une bande d'ombre intense, faisant tout le tour des eaux, emplissant les lointains d'indécision et d'obscurité. Ils donnaient l'illusion d'un espace fermé, d'une limite; ils étaient comme des rideaux tirés sur l'infini, comme des voiles tendus pour cacher de trops gigantesques mystères qui eussent troublé l'imagination des hommes.

Ce matin-là, autour du petit assemblage de planches qui portait Yann et Sylvestre, le monde changeant du dehors avait pris un aspect de recueillement immense; il s'était arrangé en sanctuaire, et les gerbes de rayons, qui entraient par les traînées de cette voute de temple, s'allongaient en reflets sur l'eau immobile comme sur un parvis de marbre. Et puis, peu à peu, on vit s'éclairer très loin une autre chimère: une surte de découpure 
rosće très haute, qui était un promontoire de la sombre Islande....

Pierre Loti.

Dawn in the Lighthouse

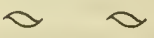

(From Many Inzentions)

F the English south-coast Lights, that of St. Cecilia-under-the-Cliff is the most powerful, for it guards a very foggy coast. When the seamist veils all, St. Cecilia turns a hooded head to the sea and sings a song of two words once every minute. From the land that song resembles the bellowing of a brazen bull; but off-shore they understand, and the steamers grunt gratefully in answer.

Fenwick, who was on duty one night, lent me a pair of black glass spectacles, without which no man can look at the Light unblinded, and busied himself in last touches to the lenses before twilight fell. The width of the English Channel beneath us lay as smooth and as many-coloured as the inside of an oyster shell. A little Sunderland cargo-boat had made her signal to Lloyd's Agency, half a mile up the coast, and was lumbering down to the sunset, her wake lying white behind her. One star came out over the cliffs, the waters turned to lead colour, and St. Cecilia's Light shot out across the sea in eight long pencils that 
wheeled slowly from right to left, melted into one beam of solid light laid down directly in front of the tower, dissolved again into eight, and passed away. The light-frame of the thousand lenses circled on its rollers, and the compressed-air engine that drove it hummed like a bluebottle under a glass. The hand of the indicator on the wall pulsed from mark to mark. Eight pulsebeats timed one half-revolution of the Light; neither more nor less. . . .

"Look," he answered, and I saw that the dead sea-mist had risen out of the lifeless sea and wrapped us while my back had been turned. The pencils of the Light marched staggeringly across tilted floors of white cloud. From the balcony round the light-room the white walls of the lighthouse ran down into swirling, smoking space. The noise of the tide coming in very lazily over the rocks was choked down to a thick drawl. . .

. Fenwick left his chair, passed to the Light, touched something that clicked, and the glare ceased with a suddenness that was pain. Day had come, and the Channel needed St. Cecilia no longer. The sea-fog rolled back from the cliffs in trailed wreaths and dragged patches, as the sun rose and made the clead sea alive and splendid. The stillness of the morning held us both silent as we stepped on the balcony. A 
lark went up from the cliffs behind St. Cecilia, and we smelt a smell of cows in the lighthouse pastures below.

Then we were both at liberty to thank the Lord for another day of clean and wholesome life.

\section{Rudyard Kipling.}

(From The Sand's of Pleasure)

JUST before dawn he went out again to the $\int$ balcony, and watched the grey daylight filter and spread through the darkness. As it increased, the rays from the light fell shorter and fainter, helpless to prevail, for all their power, against the light that was coming. Out of the gloom rose the coasts and the land, and with the falling of the wind and the absence of its salt odours, the smell from the earth came off, rich and fragrant, in the morning air. The waves, unfretted by the wind, rolled in deep and heavy, at first a dull grey, and then, as the light increased, a furrowed sea of deepest indigo. The eastern horizon was banked with clouds, above which the reflection of the hidden fires of dawn began to wash the sky with opalescent tints, and to kindle a glow of saffron on the crests of the breaking waves. Suddenly, behind him, Richard heard a click; the glare ceased, and the roar of the ventilator died away. 
"Sunrise, sir," said the keeper, with his watch in his hand; and together they looked eastward, where an edge of gold was eating into the banked clouds on the horizon.

Filson Young.

\section{Dawn on a Cargo Boat}

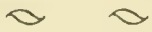

(From A Tramp's Notcbook)

$\mathrm{B}^{\mathrm{UT}}$ that's the dawn :

Morning, and the glory of it, the grey wash of Eternity; sea-grey and world-grey and skygrey, all in one great wash with a little whiteness standing for daylight. Beyond the illimitable wash where the sea breaks against the sky is the sun; source of all, strength of all. And there is no sleep to wash out of our eyes before we catch up strength from it, and cncouragement. Lately we might have raised the Ajax cry, "In the light, in the light, destroy us"; but now we see the little sea-plant of grey-green grow in the east, and we are strong. There is light, or a blight, a greyness out ahead, and the deck whitens all awash, and the "old man" shivers in his oilskin coat as he hangs on to a pin in the rail to watclu us. The poop is wet and gleaming, wet with the spray of following seas, and, as our ship rolls, the swash of shipped scas hisses, and her clcanness is as the cleanness of something newly varnished. Once 
and again as she rolls (the wind now quartering) the scuppers spout geyser-like and gurgle... The light leapt from crest to crest, and a little pale yellow blossom of blown dawn peeped out of the grey. Like a touch of fire it reanimated our washed and reeling world; we laughed as we dropped down after our three hours' battle with the demons of the air. It was morning. . . .

Morley Roberts. 
WEATHER 
The whole of the luggage was carelessly thrown together, and among which were the poor suffering passengers, many of them ladies, rolling in sickness and everything that was filthy, with the risk of having their brains beat out. Our getting into the boat which came alongside was so far bad that we thought it miraculous that only two passengers fell overboard. All our campaigning was a joke, for the time it lasted, to these four hours and a half.

Colonel Peter Hawker (from his Diary). 


\section{CALM}

Calm on the Mediterranean

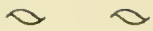

(From Voyage en Orient)

I $E$ vent est mort et rien n'annonce son retour. La surface du golfe n'a pas un pli ; la mer est si plane qu'on y distingue çà et là l'impression des ailes transparentes des moustiques qui flottent sur ce miroir, et qui seules le ternissent à cette heure. Voila donc à quel degré de calme et de mansuẹ́tude peut descendre cet élément qui soulève les vaisseaux à trois ponts sans connâitre leur poids, qui ronge des lieues de rivage, use des collines et fend les rochers, brise les montagnes sous le choc de ses lames mugissantes! Rien n'est si doux que ce qui est fort. ...

... Un calme absolu nous a surpris à douze lieues en mer; il dure encore. Aucun vent dans le ciel, si ce n'est quelques brises perdues qui viennent de temps en temps froisser les voiles des deux vaisseaux; elles font rendre a ces grandes voiles une palpitation sonore, un battement irregulier semblable au battement convulsif des ailes d'un oiseau qui meurt; la mer est plane et polie comme la lame d'un sabre; pas une ride, mais, de loin en loin, de larges ondulations cylindriques qui se glissent sous le mavire et 
l'ébranlent comme un tremblement souterrain. Toute la masse des mâts, des vergues, des haubans, des voiles, craque et frémit alors, ainsi que sous un vent trop lourd. . . .

. . L La mer, à mon réveil, après une nuit orageuse, semble jouer avec le reste du vent d'hiver; l'écume la couvre encore comme les flocons à demi essuyés qui tachent les flancs du cheval fatigué d'une longue course, ou comme ceux que son mors secoue quand il abaisse et relève la tête, impatient d'une nouvelle carrière. Les vagues courent vite, irregulièrement, mais légères, peu profondes, transparentes; cette mer ressemble à un champ de belle avoine ondoyant aux brises d'une matinée de printemps après une nuit d'averse. . . .

\section{Alphonse Marie Louis Lamarline.}

The Mystery of a Calm

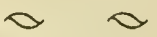

(From $A$ Sack of Shakings)

$\mathrm{HOW}$ shall I speak of the voice of the calm? How describe that sound which mortal ear cannot hear? The pen of the inspired writers alone might successfully undertake such a task, so closely in touch as they were with the Master Mind. "When the morning stars sang together, and all the Sons of God shouted for joy." Something akin to this sublime daring of language is 
needed to convey a just idea of what floods the soul when alone upon the face of the deep in a perfect calm. The scale of that heavenly harmony is out of our range. We can only by some subtle alchemy of the brain distil from that celestial silence the voices of angels and archangels and all the glorious company of heaven. Between us and them is but a step, but it is the threshold of the timeless dimension. Again and again I have seen men, racked through and through with a very agony of delight, dash aside the thralls that held them, sometimes witl passionate tears, more often with raging words that grated harshly upon the velvet stillness. They felt the burden of the flesh grievous, since it shut them out from what they dimly felt must be bliss unutterable, not to be contained in any earthen vessel. On land a thousand things, even in a desert, distract the attention, loose the mind's tension even when utterly alone. But at sea, the centre of one vast glassy circle, shut in on every hand by a perfect demi-globe as flawless as the mirror whereon you float, with even the softest undulation imperceptible, and no more motion of the atmosphere than there is in a perfect vacuum, there is absolutely nothing to come between the Soul of Man and the Infinite Silences of Creation. There and there only is it possible to realize what underlies that mighty line, "There was silence in Heaven for the space of 
half an hour." Few indeed are the men, however rough and unthinking, that are not quieted and impressed by the marvel of a perfect calm. But the tension is too great to be borne long with patience. Men feel that this majestic environment is too redolent of the coming paradise to be supportable by flesh and blood. They long with intense desire for a breeze, for motion, for a change of any sort. So much so that long-continued calm is dreaded by seamen more than any other phase of sea-experience. And yet it is for a time lovely beyond description, soothing the jarring nerves and solemnizing every faculty as if one were to be shut in before the Shekinah in the Holy of Holies. It is like the Peace of God.

$$
\text { F. T. Bullen. }
$$

\section{Calm off the Horn}
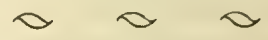

(From A Tarpaulin Muster)

$\mathrm{FF}$ Cape Horn there are but two kinds of weather, neither one of them a pleasant kind. If you get the fine kind, it is dead calm, without enough wind to lift the wind vane. The sea lies oily and horrible, heaving in slow, solemn swells, the colour of soup. The sky closes down upon the sea all round you, the same colour as the water. The sun never shines over those seas, though sometimes there is a red flush, in the east 
or in the west, to hint that somewhere, very far away, there is daylight brightening the face of things.

If you are in a ship in the Cape Horn calm, you forge ahead, under all sail, a quarter of a mile an hour. The swell heaves you up and drops you, in long, slow, gradual movements, in a rhythm beautiful to mark. You roll, too, in a sort of horrible crescendo, half a dozen rolls and a lull. You can never tell when she will begin to roll. She will begin quite suddenly, for no apparent reason. She will go over and over with a rattling clatter of blocks and chains. Then she will swing back, groaning along the length of her, to slat the great sails and set the reef points flogging, to a great clack and jangle of staysail sheets. Then over she will go again, and back, and again over, rolling further each time. At the last of lier rolls there comes a great clattering of tins, as the galley gear and whack pots slither across to leeward, followed by cursing seamen. The iron swing-pots bang to and fro. The straining and groaning sounds along her length. Every block aloft clacks and whines. The sea splashes up the scuppers. The sleepers curse her from their bunks for a drunken drogher. Then she lets up and stands on her dignity, and rolls no more for perlaps another quarter of an hour.

John Masefiele. 


\section{I. CHANGE OF WEATHER}

In the South Seas
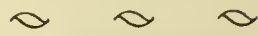

(From Matelot)

M AIS un soir, une immense nuée obscure surgit 1 à l'horizon du sud, envahissante, formant tout de suite voute de ténèbres. Et le bon vent tomba, et, dans l'air subitement refroidi, deux grands albatros, les premiers, apparurent,- bêtes de l'Austral sombre. Dans la lumière diminuée, dans l'humidité pénétrante qu'on sentait descendre comme un manteau glacé sur les épaules, c'était sinistre de s'enfoncer, à une tombée de nuit, dans ces régions incertaines que recouvrait ce voile de nuages et où les pires surprises du temps étaient à redouter.

Le lendemain, tout avait changé d'aspect à bord de la Saône que le soleil n'éclairait plus. Au lieu des chapeaux de paille, au lieu des gais costumes en toile propre et blanche, on voyait reparaître les laines bleues, râpées, fanées, trouees de mites et de cancrelas, et les vieux bonnets de fatigue enfoncés plus bas que les oreilles. Et, sur le pont, c'était une agitation extraordinaire parmi les manœuvriers. De solides voiles toutes neuves arrivaient d'en bas, apportées à l'épaule par des rangées d'hommes, en longs cortèges oscillantes. 
Des filins de couleur blonde, neufs aussi et sentant le goudron, sortaient des cales; les matelots s'attelaient dessus, puis prenaient leur course et les tiraient, vite, vite, comme des serpents sans fin.

Tout cela se faisait en musique et, dans l'air devenu âpre, salubre aux poitrines vigoureuses mais mortel aux affaiblis, les sifflets d'argent constamment roulaient leurs trilles suraigus. On se préparait à la lutte prochaine contre le vent et contre la mer des zones mauvaises. Ils tournoyaient, les albatros, très rapprochés-les mêmes qu'hier, acharnés peut-être pour des semaines à suivre le sillage du navire,-et ils criaient sans trêve de leur vilaine voix gémissante, qui semble le grincement d'une girouette ou d'une poulie rouillée. Et le quartier-maître de l'arrière, outré de toujours les entendre, leur disait, son sifflet serré entre les dents et leur montrant le poing :-

"Tu ferais pas mal de graisser un peu ta poulie, toi, les deux grands sales moincaux, là-bas !"

Le fait est qu'ils avaient l'air de chanter à la mort, ces deux albatros.

P'ierre Loti. 


\section{FOG}

\section{The Walls of Grey}
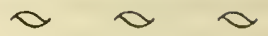

(From The Sea Wolf)

THEN we entered the fog. It was about us, veiling and hiding us in its dense wet gauze.

The sudden transition was startling. The moment before we had been leaping through the sunshine, the clear sky above us, the sea breaking and rolling wide to the horizon, and a ship, vomiting smoke and fire and iron missiles, rushing madly upon us. And at once, as in an instant's leap, the sun was blotted out, there was no sky, even our mastheads were lost to view, and our horizon was such as tear-blinded eyes may see. The grey mist drove by us like a rain. Every woollen filament of our garments, every hair of our heads and faces, was jewelled with a crystal globule. The shrouds were wet with moisture; it dripped from our rigging overhead; and on the underside of our booms drops of water took shape in long swaying lines, which were detached and flung to the deck in mimic showers at each surge of the schooner. I was aware of a pent, stifled feeling. As the sounds of the ship, thrusting herself through the waves, were hurled back upon us by the fog, so were one's thoughts. The mind recoiled from contemplation of a world be- 
yond this wet veil which wrapped us around. This was the world, the universe itself, its bounds so near one felt impelled to reach out both arms and push them back. It was impossble that the rest could be beyond these walls of grey. The rest was a dream, no more than the memory of a dream.

Jack London.

\section{STORM}

The Sorrowful Maister's Predicament

(From Rare Adventiures)

THE sorrowful Maister, seeing nothing but shipwrack tooke the Helme in hand, directing his course to rush upon the face of a low Rocke, whereupon the sea most fearefully broke. As we touched the Mariners contending who should first leape out, some fell over-boord, and those that got land were pulled backe by the reciprocating waves : Neither in all this time durst $I$ once move; for they had formerly sworne, if I pressed to escape, before the rest were first forth, they would throw me headlong into the sca: So bcing two wayes in danger of death, I patiently offered up my prayers to God.

At our first encounter with the Rocks, (our foredecks, and Boates gallery being broke, and a 
great Lake made) the recoiling waves brought us backe from the Shelfes a great way; which the poore Master perceiving, and that there were seven men drowned, and eleven persons alive, cryed with a loud voyce: $\mathrm{Be}$ of good courage, take up oares, and row hastily ; it may be, before the Barke sinke, we shall attaine to yonder Cave, which then appeared to our sight: Every man working for his owne deliverance (as it pleased God) we got the same with good fortune: for no sooner were we disbarked, and I also left the last man, but the Boat immediately sunke. There was nothing saved but my Coffino, which I kept alwaies in my armes.

William Lithgoue.

\section{The Fires of St. Elmo}

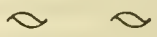

(From Voyages; Hakluyt Soc., trans.)

THE Captain, therefore, ordered the ships to 1 proceed on their course until the 4 th of February, when they found themselves near another island, which, being of so little profit, did them much harm, and the previous night had been passed in great trouble. For there was a cross sea, and the force of the wind was so great that they could not run before it, not even under courses. The night closed in, and soon afterwards a black and thick mass of clouds rose from the 
N.E., directing its course on the ships with such speed and fury that all were obliged to seek safety. The ships received the squall, heeling over on their sides, while the sea rose, seeming to intend to engulph them. The lightning, which traversed the air, seemed to leave the heavens torn. It was a great tempest, with many and very great peals of thunder. Three thunderbolts fell, which caused no small confusion; while the water did not cease to fall from the heavens, with dark and thick rain, combined with squalls of wind, from which the least harm that could be hoped for was to tear out the masts. They lighted lanterns in the castles to show to the other ships. But terrified voices continued to be heard from the sailors, with cries of "Keep clear! Luff! Keep away!" fearing that there would be collisions. All was hurry, confusion, and trouble, for it was a fearful night, and the end uncertain. Some cried, "Make sail!" others, "Sound the well!" We were ready to cut away the masts, and had up the axes. In short, all was tribulation and anxiety, chiefly because there was no certainty whether there was any safety where the ships were.

The Father Commissary, with a cross In his hands, stood until the weather cleared, offering up prayers. Then, as the sailors call it, St. Elmo appeared, whom they saluted three times with great devotion. At length the night came to an end, 
which, owing to the horror and confusion, appeared very long; but they were saved (after God), owing to the strength and soundness of the ships.

Pedro Fernandes de Quiros.

\section{The Fury of It}
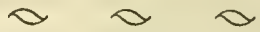

(From the Journal; trans.)

NEVER before have I seen the sea so high, so horrible, so covered with foam. The wind prevented our advance, even as far as some sheltering headland, and kept me out on this sea, which seemed suffused with blood and boiled like a cauldron on a great fire. Never before had the sky looked so terrible. Day and night it blazed like a furnace, sending out such streaks of fire that every moment I looked to see the masts carried away. The thunderbolts fell around with such inconceivable fury that we all thought the vessel must be struck. All this time the rain fell without ceasing: not mere rain indeed, but truly another deluge. 
Scylla and Charybdis

(From The Fifth Book of the Good Pantagruel; trans.)

THEN the gusts increased, and by fits blowed all at once from several quarters: yet we neither settled nor braded up close our sails, but only let fly the sheets, not to go against the master of the ship's direction; and thus having let go amain, lest we should spend our topsails, or the ship's quick-side should lie in the water, and she be overset, we lay by and run adrift, that is, in a landloper's phrase, we temporised it. For he assured us, that, as these gusts and whirlwinds would not do us much good, so they could not do us much harm, considering their easiness and pleasant strife, as also the clearness of the sky, and ealmness of the current. So that we were to observe the philosopher's rule, bear and forbear; that is, trim, or go according to the time.

However, these whirlwinds and gusts lasted so long, that we persuaded the master to let us go and lie at trie with our main course; that is, to haul the tack aboarcl, the sheet close aft, the bowline set up, and the helm tied close aboard; so after a stormy gale of wind, we broke through the whirlwind. Rut 'twas like falling into Scylla to avoid Claryludis (out of the frying-pan into the fire). For we had not sailed a league, e'er our 
ships were stranded upon some sands, such as are the flats of St. Maixant.

François Rabelais.

\section{Collision between the Erebus and Terror}

(From A Voyage of Discovery)

A LARGE berg was seen ahead, and quite close to us; the ship was immediately hauled to the wind on the port tack, with the expectation of being able to weather it; but just at this moment the Terror was observed running down upon us, under her topsails and foresail; and as it was impossible for her to clear both the berg and the Erebus, collision was inevitable. We instantly hove all aback to diminish the violence of the shock; but the concussion when she struck us was such as to throw almost every one off his feet; our bowsprit, fore-topmast, and other smaller spars, were carried away; and the ships hanging together, entangled by their rigging, and dashing against each other with fearful violence, were falling down upon the weather face of the lofty berg under our lee, against which the waves were breaking and foaming to near the summit of its perpendicular cliffs. Sometimes she rose high above us, almost exposing her keel to view, and again descended as we in our turn rose to the top 
of the wave, threatening to bury her beneath us, whilst the crashing of the breaking upperworks and boats increased the horror of the scene. Providentially they gradually forged past each other, and separated before we drifted down amongst the foaming breakers, and we had the gratification of seeing her clear the end of the berg, and of feeling that she was safe. But she left us completely disabled; the wreck of the spars so encumbered the lower yards, that we were unable to make sail, so as to get headway on the ship ; nor had we room to wear round, being by this time so close to the berg that the waves, when they struck against it, threw back their sprays into the ship. The only way left us to extricate ourselves from this awful and appalling situation was by resorting to the hazardous expedient of a stern-board, which nothing could justify during such a gale and with so high a sea running, but to avert the danger which every moment threatened us of being clashed to pieces. The heavy rolling of the vessel, and the probability of the masts giving way each time the lower yard-arms struck against the cliffs, which were towering high above our mastheads, rendered it a service of extreme danger to loose the inainsail; but no sooner was the order given, than the daring spirit of the British seaman manifested itself - the men ran up the rigging with as much alacrity as on any 
ordinary occasion; and although more than once driven off the yard, they after a short time succeeded in loosing the sail. Amidst the roar of the wind and sea, it was difficult both to hear and to execute the orders that were given, so that it was three-quarters of an hour before we could get the yards braced bye, and the maintack hauled on board sharp aback-an expedient that perhaps had never before been resorted to by seamen in such weather; but it had the desired effect; the ship gathered stern-way, plunging her stern into the sea, washing away the gig and quarter boats, and with her lower yardarms scraping the rugged face of the berg, we in a few minutes reached its western termination; the "under tow," as it is called, or the reaction of the water from its vertical cliffs, alone preventing us being driven to atoms against it.

Sir James Ross.

A Landsman in a Storm

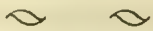

(From A Narrative of a Voyage Round the World; trans.)

At Sea, in latitude $4^{\circ}$ North.

A GRAY cloud, the forerumer of a storm, appears on the horizon; it rises rapidly, charged with hail, spreads itself out afar, covers great part of the sky, darkens the atmosphere, and 
diffuses a sulphureous smell. A dull, hollow roaring soon announces to the attentive mariner the impending danger. . . The merry songs have ceased, and are succeeded by an alarming silence. The danger is measured with a glance. The captain speaks; the men fly to obey his orders. The furled sails no longer catch the wind, which roars and howls among the rigging: the ship gradually yields to the rapid motion of the billows. Perched on the tops of the masts, and at the extremities of the yards, the sailors display redoubled boldness. An order is scarcely given before it is executed. They are no longer those faint-hearted cowards, described by barbarous historians as trembling at the approach of danger; they are, on the contrary, intrepid mariners, whom the combined elenients are incapable of appalling. Whether touching the clouds, or at the bottom of the abyss, they are constantly the same; and they care as little for the thunderbolt as for the sunken rock. But the uproar increases; the cloud hovers over the vessel ; wave dashes against wave; lightnings rend the cloud; from its murky sides burst tor. rents of wind and hail. The ship is carried away. The rapidity of its motions prevents any attempt to counteract them; and the profoundest darkness would render such an attempt useless. The roaring of the waves, the pealing of the thunder, the howling of the cordage, the cracking of the tackle, 
So

drown the voice: none is heard save that of the tempest.

But the wind subsides; light returns; the thunder rolls at a distance; the ear calmly follows its reverberations; the seaman with weary hand points to the flashing lightning, now too distant to alarm him; he forgets in a trice the dangers he has just escaped, and seems by his renewed songs to provoke fresh perils.

I know not, my friend, whether I have given you a faint idea of a storm which overtook us today in the fourth degree of north latitude. Ah! what a delightful picture of Paris could I have drawn for you! Our gentry, however, say that it was only a squall.

$$
\text { J. Arago. }
$$

Helplessness of the Ship

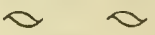

(From Pêcheur d'Islande)

$\mathrm{E}^{\text {LLE fuyait devant le temps, la Marie, fuyait }}$ toujours plus vite; et le temps fuyait aussidevant je ne sais quoi de mystérieux et de terrible. La brise, la mer, la Marie, les nuages, tout était pris d'un même affolement de fuite et de vitesse dans le même sens. Ce qui détalait le plus vite c'était le vent, puis les grosses levées de houle, plus lourdes, plus lentes, courant après lui; puis la Marie entrainée dans ce mouvement de tout. Les 
lames la poursuivaient, avec leurs crêtes blêmes qui se roulaient dans une perpétuclle chute, et elle,-toujours rattrapée, toujours dépassée,-leur échappait tout de même, aı moyen d'un sillage liabile qu'elle se faisait derrière, d'un remous où leur fureur se brisait.

Et dans cette allure de fuite, ce qu'on éprouvait surtout, c'était une illusion de légèreté; sans aucune peine ni effort, on se sentait bondir. Quand la Marie montait sur ces lames, c'était sans sccousse, comme si le vent l'eût enlevée; et sa redescente après était comme une glissade, faisant éprouver ce tressaillement du ventre qu'on a dans les chutes simulées des "chars russes" ou dans celles imaginaires des rêves. Elle glissait comme à reculons, la montagne fuyante se dérobant sous clle pour continuer de courir, et alors elle était replongée dans un de ces grands creux qui couraient aussi; sans se meurtrir, elle en touchait le fond horrible, dans un éclaboussement d'eau qui ne la mouillait même pas, mais qui fuyait comme tout le reste; qui fuyait et s'évanouissait en avant comme de la fumće, comme rien. . . .

Au fond de ces creux, il faisait plus noir, ct après chaque laıne passće, on regardait derrière soi arriver l'autre; l'autre encore plus grande, qui se clressait toute verte par transparence; qui se dépéchait d'approcher, avec des contournements 
furieux, des volutes prêtes à se renfermer, un air de dire: "Attends que je t'attrape, et je t'engouffre...."

\section{Picrre Loti.}

\section{An Emigrant Ship in Bad Weather}

(From Blau Wasser)

$\mathrm{E}^{I N}$ eigenthümlich schriller Laut pfiff da über die See und das Schiff neigte sich so plötzlich und scharf nach Lee hiniiber, dass, wer nicht fest stand, zur Seite rutschte und rollte und alles an Deck stehende lockere Geschirr und Geräth polternd nach Larbord ïber kollerte.

"Steht bei den Fallen! Los mit den Bramfallen, um Euer Leben, los mit den Marsen!" schrie in diesem Augenblick die Stimme des Kapitäns gellend über Deck. Die Matrosen sprangen erschreckt herbei, aber sie selber hatten Noth, sich im ersten Augenblick der Ueberraschung festzuklammern und nicht ebenfalls nach Lee $z u$ geworfen $z u$ werden, und ehe sie nur die Falle, an denen die oberen Raaen befestigt waren, erreichen und, wie der Befehl lautete, abwerfen konnten, brach es und knatterte es oben in den Stengen und kam, unter dem Heulen der plötzlich aufgesprungenen $\mathrm{Bö}$, rasselnd an Deck nieder, zwischen die ängstlich aufschreienden Passagiere hinein. 
Noch standen die unteren Masten, und durch die niedergeschmetterten Stengen hatte der so plötzlich herangebrauste Sturm wenigstens seine grösste Macht auf das Schiff verloren, das sich langsam wieder aufrichtete. Aber die Kaptaube trieb auch, ein halbes Wrack, auf den WVellen, und unter dem Flattern der Segel, da der Mann am Steuer in plötzlichem Schreck das Schiff gerade in den Wind hinein gedreht hatte, dass es nicht den mindesten Fortgang mehr durch's Wasser machte, sprangen die Matrosen jetzt an ihre Plätze, lösten die Schoten des grossen Segels und der Fock, liessen die Clüver nieder-der Clüverbaum war ebenfalls abgebrochen-und warfen das Besansegel los.

In furchtbarer Schnelle hatte sich indessen die im Westen aufgekommene Wand gehoben; von der Windsbraut getragen kain sie herauf, und wie die Leute nah dabei waren, das indessen wieder scinem Steuer gehorchende Schiff von allem frei zu kappen, was darum herhing; an Deck zu ziehen was zu retten war, und das Uebrige über Bord zu schneiden, kam ein fluthender Regen wolkenbruchartig niedergestrümt, sammelte sich an Deck und schlug, da er so rasch gar nicht durch die jetzt noch überdies nit Segel und Tauwerk verstopften Speygaten ablaufen konnte, in die noch offenen Luken hinein. 
Die Passagiere hatten den ersten Anprall des Sturmes mit dumpfem, starrem Schweigen hingenommen. So plötzlich war das Unwetter aus volkommen heiterer Luft über sie hereingebrochen, so wild und toll schlugen ihnen die Stengen und Segel dazu um die Köpfe, dass sie die Grösse des Unfalls nicht einmal gleich begriffen. Nur die Frauen bemächtigten sich instinctartig zuerst der Kinder, diese vor dem fallenden Hölzern, wenn es sein musste, mit den eigenen Körpern zu decken, gewannen aber auch zuerst ihre Stimmen wieder und schrien und wehklagten jetze in das Heulen und Brausen der Elemente hinein.

Hatten die Seeleute übrigens die Passagiere, die ihnen mehr als je überall im Wege waren, noch bis jetzt unbelästigt an Deck gelassen, so war das die alleinige Ursache gewesen, dass sie auch noch nicht einen Augenblick Zeit bekommen, sich mit ihnen zu beschäftigen. Jetzt aber, wo der niederströmende, Regen seine Fluth selbst auch in die noch offenen Luken des Zwischendecks ergoss, und die darunter liegende Fracht zu beschädigen drohte, änderte sich die Sache, und die Passagiere wurden beordert nieder zu klettern, damit die Luken geschlossen werden könnten.

Unter dem Schreien und Jammern der Frauen und Kinder und dem Fluchen der Männer, die 
sich grösstentheils nur ungern dem Befehle fügten, wurde das endlich bewerkstelligt, und die übergehobenen Luken deckten wenige Minuten später den unteren, dunklen, dumpfigen Raum des Zwischendecks mit Nacht und Schweigen. Die Mannschaft an Deck bekam freien Raum, das zerrissene Takelwerk, wie die zersplitterten Masten, so viel als möglich in Ordnung zu bringen, das Schiff wenigstens regieren zu können, und als das geschehen war, änderte der Kapitän ihren Cours. Mit den wenigen noch möglichen Segeln konnten sie sich aber nur langsam durch die rasch erregte Fluth fortbewegen, und das Sicherste für sie war, nach Norden hinauf zu laufen, um mit Hülfe der Leuchtthürme einen schützenden Hafen zu erreichen, wo der erlittene Schaden wieder ordentlich reparirt werden konnte. Mit dem Wrack durfte er nicht wagen, seine Reise durch den atlantischen Ocean fortzusetzen.

\section{Fricdrich Gerstaecker.}

The Breaking Wave
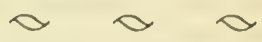

(From The Cruise of the "Millye")

THE weather was indeed getting rapidly worse ; the screaming sea-birds flew in like drifts of snow, scarcely distinguishable from the driving foamnakes; the scud came past in soaking wreaths like flashes of white vapour from the safety-valve 
of a steam-boller. Suddenly the wind fell to a dead calm; not a breath fanned us; not a leaf stirred; the rain-drops glittered on the pale-green velvet of the ragged and ever-twittering but now motionless leaves of the plantain, like silver globules frozen there; the reports of the guns grew sharper in the lull, the cries shriller, and the general tumult and uproar of the conflict swelled fearfully; while the white smoke rose up, shrouding the vessels and entire cove from my sight.

The clouds above us, surcharged with fire and water, formed a leaden-coloured arch over the entrance to the cove that spanned the uproar of dark white-crested waves, boiling and rolling in smoky wreaths and lancing out ragged shreds from their lower edges, that shot down and shortened like a fringe of streamers, from which the forked lightning "crankled" out every now and then clear and bright.

A column of dense black smoke, thickly starred with red sparks, now boiled up past the edge of the cliff under me; presently it became streaked with tongues of bright hissing flame, which ran up the rigging, diverging along every rope as if it had been a galvanic wire, twisting serpent-like round the Mosca's masts and higher spars, and licking the wet furled sails like boa-constrictors fitting their prey to be devoured. See how the fire insinuates itself into the dry creases of the canvas, driving 
out the moisture from the massive folds in white steam; now the sails catch in earnest-they drop in glowing flakes of tinder from the yards-there the blue-and-white pemnant and ensign are scorched away, and blown off in tiny flashes; while in the lulls of the gale we distinctly hear the roaring and crackling of the fire as it rages in the hull of the doomed vessel below.

"I say, Quacco, mind we don't get a hoist, my man-see we be not too near-there! Don't you hear how the guns go off as the metal gets heated, for there is not a soul on board?"

It never rains but it pours. "Hark! An earthquake!" And as if a volcano had burst forth beneath our feet, at this instant of time the pirate schooner under the cliff blew up with an explosion that shook earth, air, and water-shooting the pieces of burning wreck in every direction, that hissed like meteors through the storm, and fell thickly all around us.

"The Midge! the Midge! she slides out of the smoke! See! She gains the offing!"

But the avenger of blood is behind; for the Spider had now cleared the harbour's mouth and was in hot pursuit. The felucca with her sails-a whole constellation of shot-holes in them-doublereefed, tearing and plunging through it ; her sharp stem flashing up the water into smoke in a vain attempt to weather the sandy point. 
"Won't do, my boy! You cannot, carry to it as you will, clear the land as you are standing; you must tack soon, unless you mean to jump the little beauty over it." As I spoke she hove about and stood across the schooner, exchanging broadsides gallantly. "Well done, little one!" The Spider tacked also and stood after her. A gun! Another! Both replied to by the felucca, the musketry peppering away all the while from each essel; the tiny white puffs instantly obliterated $y$ the foam-drift; and now neither fired a shot.

The gale at this moment came down in thunder; all above as black as night, all below as white as wool. The Spider shortens sail just in time; the Midge not a pistol shot ahead on the weather bow. See! the squall strikes her-her tall lateen sail shines through the more than twilight darkness and the driving rain and spray, like a sea-bird's wing. Mercy! how she lies over ! She sinks in the trough of the sea! Now she rises again and breasts it gallantly! There! that's over her bodily; her sails are dark and sea-washed threeparts up. Look how the clear green water, as she lurches, pours out of the afterleech of the sail like a cascade! Now she is buried again; nobuoyant as a cork, she dances over it like a wild duck! See how she tips up her round stern and slides down the liquid hollow! Once more she catches the breeze on the opposite rise of the sea, 
her sails tearing her along up the watery acclivity as if they would drag the spars out of her. Now she rushes on the curl of the wave, with her bows and a third of her keel hove out into the air, as if she were going to shoot across like a flying-fish into the swelling bosom of the next sea. Once more she is hove on her beam-ends and hid by an intervening billow. Ha! what a blinding flash, as the blue forked lightning glances from sky to sea right over where I saw her last! Hark! the splitting crash and stunning reverberations of the shaking thunder, rolling through the empyrean loud as an archangel's voice, until earth and air tremble again. She rights-she rights! There! the narrow shred of white canvas gleams again through the mist in the very fiercest of the squall -yes, there! No! God of my fathers!

IT IS BUT A BREAKING WAVE!

Michael Scott.

Responsibility of the Helmsman

(From The Cruise of the "Cachalot")

$\mathrm{YOU}$ are running before the wind and waves, sometimes deep in the valley between two liquid mountains, sometimes high on the rolling ridge of one. You watcls anxiously the speed of the sea, trying to decide whether it or you are 
going the faster, when suddenly there seems to be a hush, almost a lull, in the uproar. You look astern and see a wall of water rising majestically higher and higher, at the same time drawing neare and nearer. Instinctively you clutch at something firm and hold your breath. Then that mighty green barrier leans forward, the ship's stern seems to settle at the same time, and, with a thundering noise as of an avalanche descending, it overwhelms you. Of course, the ship's way is deadened; she seems like a living thing overburdened, yet struggling to be free; and well it is for all hands if the helmsman be able to keep his post and his wits about him. For if he be hurt, or have fled from the terrible wave, it is an even chance that she "broaches to," that is to say, swings round broadside on to the next great wave that follows relentlessly its predecessor. Then, helpless and vulnerable, she will most probably be smashed up and founder. Many a good ship has gone with all hands to the bottom just as simply as that.

F. T. Bullen.

The Fleet in a Squall

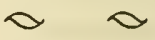

(From Roderick Random)

$W^{\mathrm{E}}$ got out of the channel with a prosperous breeze, which died away, leaving us becalmed about fifty leagues to the westward of the Lizard; 
but this state of inaction did not last long, for next night our maintop-sail was split by the wind, which, in the morning, increased to a hurricane. I was awakened by a most horrible din, occasioned by the play of the gun-carriages upon the decks above, the cracking of cabins, the howling of the wind through the shrouds, the confused noise of the ship's crew, the pipes of the boatswain and his mate, the trumpets of the lieutenants, and the clanking of the chain pumps. Morgan, who had never been at sea before, turned out in a great hurry, crying, "Cot have mercy and compassion upon us! I believe we have cot upon the confines of Lucifer and the d-n'd!" while poor Thompson lay quaking in his hammock, putting up petitions to heaven for our safety. I rose and joined the Welshman, with whom (after having fortified ourselves with brandy) I went above; but if my sense of hearing was startled before, how must my sight have been appalled in beholding the effects of the storm! The sea was swelled into billows mountain high, on the top of which our ship sometimes hung as if it were about to be precipitated to the abyss below! Sometimes we sank between two waves that rose on each side higher than our topmast-head, and threatened by dashing together to overwhelm us in a moment! Of all our flect, consisting of a hundred and fifty sail, scarce twelve appeared, and these driving under their bare poles, 
at the mercy of the tempest. At length the mast of one of them gave way, and tumbled overboard with a hideous crash! Nor was the prospect in our own ship much more agreeable: a number of officers and sailors ran backward and forward with distraction in their looks, halloaing to one another, and undetermined what they should attend to first. Some clung to the yards, endeavouring to unbend the sails that were split into a thousand pieces flapping in the wind; others tried to furl those which were yet whole, while the masts, at every pitch, bent and quivered like twigs, as if they would have shivered into innumerable splinters!

Tobias Smollett.

The Slave Ship
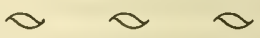

(From Modern Painters)

B UT I think the noblest sea that Turner has ever painted, and, if so, the noblest certainly ever painted by man, is that of the Slave Ship, the chief Academy picture of the Exhibition of 1840 . It is a sunset on the Atlantic, after prolonged storm; but the storm is partially lulled, and the torn and streaming rain-clouds are moving in scarlet lines to lose themselves in the hollow of the night. The whole surface of the sea included in the picture is divided into two ridges of enormous swell, not high, nor local, but a low broad heaving of the whole ocean, 
like the lifting of its bosom by deep-drawn breath after the torture of the storm. Between these two ridges the fire of the sunset falls along the trough of the sea, dyeing it with an awful but glorious light, the intense and lurid splendour of which burns like gold, and bathes like blood. Along this fiery path and valley, the tossing waves, by which the swell of the sea is restlessly divided, lift themselves in dark, indefinite, fantastic forms, each casting a faint and ghastly shadow behind it along the illumined foam. They do not rise everywhere, but three or four together in wild groups, fitfully and furiously, as the under strength of the swell compels or permits them, leaving between them treacherous spaces of level and whirling water, now lighted with green and lamp-like fire, now flashing back the gold of the declining sun, now fearfully dyed from above with the undistinguishable images of the burning clouds, which fall upon them in flakes of crimson and scarlet, and give to the reckless waves the added motion of their own fiery flying. Purple and blue, the lurid shadows of the hollow breakers are cast upon the mist of night, which gathers cold and low, advancing like the shadow of death upon the guilty ship as it labours amidst the lightning of the sea, its thin masts written upon the sky in lincs of blood, gircled with condemnation in that fearful hue which signs the sky with horror, and mixes its 
flaring flood with the sunlight, and, cast far along the desolate heave of the sepulchral waves, incarnadines the multitudinous sea.

John Ruskin.

Lightning at Sea
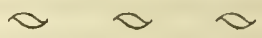

(From Mr. Midshipman Easy')

A ND the Aurora flew before the gale, under 1 her foresail and topsails close reefed. The weather was now so thick that nothing could be observed twenty yards from the vessels; the thunder peeled, and the lightning darted in every direction over the dark expanse. The watch was called as soon as the sails were trimmed, and all who could went below, wet, uncomfortable, and disappointed. . . .

At this moment a tremendous noise was heard above, a shock was felt throughout the whole ship, which trembled fore and aft as if it was about to fall into pieces; loud shrieks were followed by plaintive cries, the lower deck was filled with smoke, and the frigate was down on her beamends. Without exchanging a word, the whole of the occupants of the berth flew out, and were up the hatchway, not knowing what to think, but convinced that some dreadful accident had taken place.

On their gaining the deck, it was at once ex- 
plained; the foremast of the frigate had been struck by lightning, had been riven into several pieces, and had fallen over the larboard bow, carrying with it the main topmast and jib-boom. The jagged stump of the foremast was in flames, and burnt brightly, notwithstanding the rain fell in torrents. The ship, as soon as the foremast and main topmast had gone overboard, broachedto furiously, throwing the men over the wheel and dashing them senseless against the carronades; the forecastle, the forepart of the main deck, and even the lower deck, were spread with men, either killed or seriously wounded, or insensible from the electric shock. The frigate was on her beam-ends, and the sea broke furiously over her; all was dark as pitch, except the light from the blazing stump of the foremast, appearing like a torch, held up by the wild demons of the storm, or when occasionally the gleaming lightning cast a momentary glare, threatening every moment to repeat its attack upon the vessel, while the deafening thunder burst almost on their devoted heads.

Caphain F. Marryat.

(From The Wreck of the "Grosvenor")

I LEFT the wheel for a second or two to close one of the skylights, and, as I did so, a dash of lightning seemed to set the ship on fire, and imme- 
diately came a deafening crash of thunder. I think there is something more awful in the roar of thunder heard at sea than on shore, unless you are among mountains; you get the full intensity of it, the mighty outburst smiting the smooth surface of the water, which in itself is a wonderful vehicle of sound, and running onwards for leagues without meeting with any impedimenta to check or divert it.

I hastened to see if the lightning conductor ran clear to the water, and, finding the end of the wire coiled up in the port main-chains, flung it overboard and resumed my place at the wheel.

Now that the vast surface of cloud was well forward of overhead, I observed that its front was an almost perfect semicircle, the extremities at either point of the horizon projecting like horns. There still remained, embraced by these horns, a clear expanse of steel-coloured sky. There the sea was light, but all to starboard it was black, and the terrible shadow was fast bearing down upon the ship.

Crack I the lightning whizzed and turned the deck, spars and rigging into a network of blue fire. The peal that followed was a sudden explosion-a great dead crash, as though some mighty ponderous orb had fallen from the highest heaven upon the flooring of the sky and riven it. 
Then 1 heard the rain.

I scarcely know which was the more terrifying to see and hear-the rain, or the thunder and lightning.

It was a cataract of water falling from a prodigious clevation. It was a dense, impervious $l_{i q u i d}$ veil, shutting out all sight of sea and sky. It tore the water into foam in striking it.

Then, boom! down it came upon us.

I held on by the wheel, and the boatswain jammed himself under the grating. It was not rain only-it was hail as big as eggs; and the rain-drops were as big as eggs too.

There was not a breath of air. This terrific fall came down in perfectly perpendicular lines; and as the lightning rushed through it, it illuminated with its ghastly effulgence a broad sheet of water.

It was so dark that $I$ could not see the card in the binnacle.

The water rushed off our decks just as it would had we shipped a sea. And for the space of twenty minutes I stood stunned, deaf, blind, in the midst of a horrible and overpowering concert of pealing thunder and rushing rain, the awful gloom being rendered yet more dreadful by the dazzling flashes which passed through it.

11. Cluk Russcll. 
The Height of the Storm

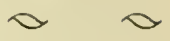

(From Miles Wallingford)

THE seas seemed crushed; the pressure of the swooping atmosphere, as the currents of the air went howling over the surface of the ocean, fairly prevented them from rising; or where a mound of water did appear, it was scooped up and borne off in spray, as the axe dubs inequalities from the log. When the clay returned, a species of lurid sombre light was diffused over the watery waste, though nothing was visible but the ocean and the ship. Even the sea-birds seemed to have taken refuge in the caverns of the adjacent coast, none reappearing with the dawn.

\section{Fenimore Cooper.}

Greeks in a Storm
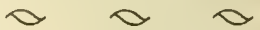

(From Eothen)

$W^{E}$ were nearing the isle of Cyprus, when there arose half a gale of wind, with a heavy chopping sea. My Greek seamen considered that the weather amounted, not to a half, but to an integral gale of wind at the very least; so they put up the helm, and scudded for twenty hours. When we neared the mainland of Anadoli the gale ceased, and a favourable breeze, springing up, soon brought 
us off Cyprus once more. Afterwards the wind changed again, but we were still able to lay our course by sailing close-hauled.

We were at length in such a position, that by holding on our course for about half an hour we should get under the lee of the island, and find ourselves in smooth water, but the wind had been gradually freshening; it now blew hard, and there was a heavy sea running.

As the grounds for alarm rose, the crew gathered together in one close group; they stood pale and grim under their hooded capotes like monks awaiting a massacre, anxiously looking by turns along the pathway of the storm, and then upon each other, and then upon the eye of the Captain, who stood by the helmsman. Presently the Hydriot came aft, more moody than ever, the bearer of fierce remonstrance against the continuing of the struggle; he received a resolute answer, and still we held our course. Soon there came a heavy sea that caught the bow of the brigantine as she lay janmed in betwixt the waves; she bowed her head low under the waters, and shuddered through all her timbers, then gallantly stood up again over the striving sea with bowsprit entire. But where were the crew? It was a crew no longer, but rather a gathering of Greek citizens;-the shout of the seamen was clianged for the murmuring of the peoplethe spirit of the old Demos was alive. The men 
came aft in a body, and loudly asked that the vessel should be put about, and that the storm be no longer tempted. Now, then, for speeches: the Captain, his eyes flashing fire, his frame all quivering with emotion-wielding his every limb, like another and a louder voice-pours forth the eloquent torrent of his threats, and his reasons, his commands, and his prayers; he promises-he vows-he swears that there is safety in holding on - safety, if Greeks will be brave! The men hear and are moved; but the gale rouses itself once more, and again the raging sea comes trampling over the timbers that are the life of all. The fierce Hydriot advances one step nearer to the Captain, and the angry growl of the people goes floating down the wind; but they listen, they waver once more, and once more resolve, then waver again, thus doubtfully hanging between the terrors of the storm and the persuasion of glorious speech, as though it were the Athenian that talked, and Philip of Macedon that thundered on the weather-bow.

Brave thoughts winged on Grecian words gained their natural mastery over Terror ; the brigantine held on her course, and reached smooth water at last.

A. W. Kinglake. 


\section{Off Cape Horn}

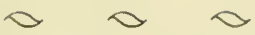

(From A Two Years' Cruise off Tierra del Fucgo)

$\mathrm{B}$ this time it was blowing very hard, and the huge seas, like rolling Alps, with broad and deep valleys of a quarter of a mile breadth between, came in an almost unbroken meridional line towards us. I soon found that we could run on no longer. In the hollow of the seas we were almost becalmed, while on their summit the wind caught us as though about to lift ship and men into the air and send all to instant destruction. The wild scud was flying fast; the sea-birds swept round and round us, eacl time narrowing their circle, as these birds almost always do when a severe gale is approaching. The high and rugged land on our left was capped in clouds, and everything had within the past hour assumed a theatening and gloomy look.

On the particular night of which I am speaking I was fatigued, and sore, and cross, and desponding. If I attempted to rouse myself and take a few spasmodic steps along the leck, a sudden lift of the sea would send me flying in a frantic manner, and with bursting force, against some fixture of the ship. If I held fast by the rigging or the bulwark rail, and glanced upon that wild 
mysterious sea, with its dark masses and snowy crests rolling terrifically on towards us, a sheet of spray, some hundred yards in length, would dash forward, and all but send me, as it did the little vessel, heeling over to the other side. Turn which way I would, look how I might, be stationary or be moving, it was all the same; and, no matter what the ship, or what the voyage, or what the skill, or what the advantages possessed, I will say that such an awful night as we had off Cape Horn, and such as hundreds and hundreds similarly experience, is a night as full of darkling terrors, ghostly and real, as any one can possibly conceive. Every sea that came seemed like a huge watermountain ready to leap upon us; and though its main body passed beneath our hull, yet in many instances perfect cataracts of water came pouring down upon us and streamed across our decks. Where the men got to I know not; for I could neither see nor hear them at such particular moments. All I could do, all I thought to do, was to hold my breath, to gaze as if with fascinated look, and watch with an all but awful fear hoping that the mighty mass of briny element would pass us scathless or without much damage. And as it passed, with the thunder roar of wind and sea alike sounding in my ear, I stood as if entranced while I pierced the darkness to try and see if all were right and well. But satisfy myself 
R. L. STEVENSON AND LLOYD OSBOURNE IO3 I could not till in frequent demands I had made the inquiry; receiving for reply, "All right, sir! nothing gone, except a bit of the spare stuff to leeward!" and so on ; only to be on the qui vive for the next giant wave, and to again sing out, as. I often did, when I saw it approach, "Look out there, men! Look out! Hold on every one of you! Hold on!"

And thus the night passed on, and thus Cape Horn demanded of us its tribute! It was cold, too; it was wretchedly uncomfortable; and fancy made me see before my eyes, even amidst that fearful darkness, a tempting and a dazzling homeside picture, where, around the parlour fire, sweet smiling faces and dear friends were congregated, as I really think in no one spot on earth but where the Anglo-Saxon dwells it is found in all its great enchantment. Truly did $l$ feel its vainly wishedfor pleasure now; but truly might I wish, and wish in vain, for nothing, save the dark clouds of heaven and the fierce tempest, with the mighty uplifted ocean, was likely to meet my view.

$$
\text { IV. P. Snow. }
$$

Finding the Wreck

(From The Wrecker)

THE morning broke with sinister brightness; the air alarmingly transparent, the sky pure, the rim of the horizon clear and strong against the 
heavens. The wind and the wild seas, now vastly swollen, indefatigably hunted us. I stood on deck choking with fear; I seemed to lose all power upon my limbs; my knees were as paper when she plunged into the murderous valleys; my heart collapsed when some black mountain fell in avalanche beside her counter, and the water, that was more than spray, swept round my ankles like a torrent. I was conscious of but one strong desire - to bear myself decently in my terrors, and, whatever should happen to my life, preserve my character: as the captain said, we are a queer kind of beasts. Breakfast time came, and I made shift to swallow some hot tea. Then I must stagger below to take the time, reading the chronometer with dizzy eyes, and marvelling the while what value there could be in observations taken in a ship launched (as ours then was) like a missile among flying seas. The forenoon dragged on in a grinding monotony of peril ; every spoke of the wheel a rash but an obliged experiment-rash as a forlorn hope, needful as the leap that lands a fireman from a burning staircase. Noon was made; the captain dined on his day's work, and I on watching him; and our place was entered on the chart with a meticulous precision which seemed to me half pitiful and half absurd, since the next eye to see that sheet of paper might be the eye of an exploring fish. One o'clock came, then two; the 
R. L. STEVENSON AND LLOYD OSBOURNE IO5 captain gloomed and chafed, as he held to the coaming of the house, and if ever I saw dormant murder in man's eye, it was in his. God help the hand that should have disobeyed him.

Of a sudden he turned towards the mate, who was doing his trick at the whecl.

"Two points on the port bow," I heard him say"; and he took the wheel himself.

Johnson nodded, wiped his eyes with the back of his wet hand, watched a chance as the ressel lunged up hill, and got to the main rigging, where he swarmed aloft. Up and up I watched him go, hanging on at cvery ugly plunge, gaining with every lull of the schooner's movement, until, clambering into the cross-trees and clinging with one arm round the masts, I could see him take one compreliensive sweep of the south-westerly horizon. The next moment he had slid down the backstay and stood on deck, with a grin, a nod, and a gesture of the finger that said "Yes"; the next again, and he was back sweating and squirming at the wheel, lys tired face streaming and smiling, and his hair and the rags and corners of his clothes lashing round him in the wind.

Nares went below, fetched up his binocular, and fell into a silent perusal of the sea-line; 1 also, with my unaided eyesight. Little by little, in that white 
waste of water, I began to make out a quarter where the whiteness appeared more condensed; the sky above was whitish likewise, and misty like a squall ; and little by little there thrilled upon my ears a note deeper and more terrible than the yelling of the gale-the long, thundering roll of breakers. Nares wiped his night-glass on his sleeve and passed it to me, motioning, as he did so, with his hand. An endless wilderness of raging billows came and went and danced in the circle of the glass; now and then a pale corner of sky, or the strong line of the horizon rugged with the heads of wares; and then of a suddencome and gone ere I could fix it, with a swallow's swiftness-one glimpse of what we had come so far and paid so dear to see: the masts and rigging of a brig pencilled on heaven, with an ensign streaming at the main, and the ragged ribbons of a topsail thrashing from the yard. Again and again, with toilful searching, I recalled that apparition. There was no sign of any land; the wreck stood between sea and sky, a thing the most isolated I had ever viewed; but as we drew nearer I perceived her to be defended by a line of breakers which drew off on either hand and marked, indeed, the nearest segment of the reef. Heavy spray hung over them like a smoke, some hundred feet into the air'; and the sound of their consecutive explosions rolled like a cannonade. 
In half an hour we were close in; for perhaps as long again we skirted that formidable barrier towards its farther side; and presently the sea began insensibly to moderate and the ship to go more sweetly. We had gained the lea of the island, as (for form's sake) I may call that ring of foam and haze and thunder; and, shaking out a reef, wore ship and headed for the passage.

\section{R. L. Stevenson and Lloyd Osbourne.}

Calm after Storm

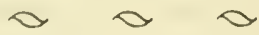

(From The Ofal Sea)

A LL night long the pound against the clifts and A the tremble of the shore! All night the whistle of the spray-laden wind as it drives through the branches of the pines! All night the curl and flash of the white crests on the open sca! By morning perhapss the wind has fallen, the clouds have vanished, the sun is forth; and yet for many hours afterward the far ocean waves kecp swashing against each other and collapsing in swirls of foam. Finaly the sea runs down, the breakers sink; and at sunset as you walk along the beach all is quict. It is hard to realize perhaps that the now smooth sea with its placid little swells could ever have worn such a savage front. but the traces of its fury still remain. The dunes 
are cut through by inlets here and piled high with wet sand there, the beaches are ripped and torn, the boulders are rolled over, scarred and battered; and the face-walls of the cliffs show where tons and tons of stone have been broken away and fallen into the sea.

Perhaps far out upon the distant reef, where the white caps are still showing, hung helplessly upon the sharp-fanged rocks, heeled over on her side with masts and rigging all down, is the battered hulk of a schooner that was driven in by the wind the night before. The little black speck that moves slowly about her fore-foot is possibly a boat of a life-saving crew that was unable to save during the storm, and is now only making a perfunctory examination of what remains. Perhaps again the little knot of fisherfolk that is seen crowded together far down the beach has found at the water's edge, half buried in the sand, a cold form with a frayed rope shirred about the waist, purplish hands with torn finger nails, and a white face with wet hair clinging about it as the tide went out. Dead, quite dead! Yes; but what cares the sea! Captain or cabin boy, prince or pauper, lover or hater, what cares the sea!

J. C. Van Dyke. 
VI

SHIIS AND SEA TRAVEL 
I hear some of our sea Yahoos find fault with my sea language, as not proper in many parts, nor now in use. I cannot help it. In my first voyages, while I was young, I was instructed by the oldest mariners, and learned to speak as they did. But I have since found that the sea I ahoos are apt, like the land ones, to become newfangled in their words, which the latter change every year. . . .

Jonathan Szvift (from "A Letter from Captain Gulliver to his Cousin Sympson"). 
Signs of Land

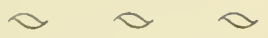

(From the Journal; Hakluyt Soc., trans.)

$A^{\mathrm{T}}$ dawn, on that Monday, they saw much more A weed appearing, like herbs from rivers, in which they found a live crab, which the Admiral kept. He says that these crabs are certain signs of land. The sea-water was found to be less salt than it had been since leaving the Canaries. The breezes were always soft. Every one was pleased, and the best sailers went ahead to sight the first land. They saw many lunny-fish, and the crew of the Nimu killed one. The Admiral here says that these signs of land come from the west, "in which direction I trust in that high God in whose hands are all victories that very soon we shall sight land." In that morning he says that a white bird was seen which has not the habit of sleeping on the sea, called rabo de junco (boatswain-bird).

Christopher Columbus. 
The Last Voyage of Christopher Columbus (From Christopher Columbus)

THE Admiral lay crippled in his cabin listening to the rush and bubble of the water, feeling the blows and recoils of the unending battle, hearkening anxiously to the straining of the timbers and the vessel's agonized complainings under the pounding of the sea. We do not know what his thoughts were; but we may guess that they looked backward rather than forward, and that often they must have been prayers that the present misery would come somehow or other to an end. Up on deck brother Bartholomew, who has developed some grievous complaint of the jaws and teeth-complaint not known to us more particularly, but dreadful enough from that description-does his duty also, with that heroic manfulness that has marked his whole career ; and somewhere in the ship young Ferdinand is sheltering from the sprays and breaking seas, finding his world of adventure grown somewhat gloomy and sordid of late, and feeling that he has now had his fill of the sea. . . . Shut your eyes and let the illusions of time and place fade from you; be with them for a moment on this last voyage; hear that eternal foaming and crashing of great waves, the shrieking of wind in cordage, the cracking and 
slatting of the sails, the mad lashing of loose ropes; the painful swinging, and climbing up and diving down, and sinking and staggering and helpless strivings of the small ship in the waste of water. The sea is as empty as chaos, nothing for days and weeks but that infinite tumbling surface and heaven of grey storm-clouds; a world of salt surges encircled in horizons by dim foam. Time and place are nothing ; the agony and pain of such moments are eternal.

But the two brothers, grim and gigantic in their sea power, subtle as the wind itself in their sea wit, win the battle. Over the thousands of miles of angry surges they urge that small ship towards calm and safety, until one day the sea begins to abate a little, and through the spray and tumult of waters the dim loom of land is seen. The sea falls back disappointed and fully conquered by Christopher Columbus, whose ship, battered, crippled, and strained, comes back out of the wilderness of waters and glides quietly into the smooth harbour of San Lucar, November 7, 1504 . "There were no guns or bells to greet the Admiral; his only salute was in the thuncler of the conquered seas; and he was carried ashore to San Lucar, and thence to Seville, a sick and broken man.

\section{Filson Young.}


The Benefits of Navigation

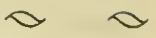

(From Three Voyages)

$\mathrm{O}$

$\mathrm{NE}$ of the excellentest artes that ever hath bin devised is the arte of navigation, which in times past was so raw and unknowen, that no man durst travel by sea, saving only alongst the shore: and if by wind, currant, or tempest, he were driven against his will so far from the land that he lost the sight thereof, he made no other accompte but to be cast away, his vessell was so rude and his skill so little.

11. Frobisher.

(From Three Voyages 10 the Arctic Regions; Hakluyt Soc., trans.)

$I^{T}$ is a most certaine and an assured assertion, that nothing doth more benefit and further the common-wealth (specially these countries ${ }^{1}$ ) then the art and knowledge of nauigation, in regard that such countries and nations as are strong and mightie at sea, haue the meanes and ready way to draw, fetch, and bring vnto them for their maintenaunce, all the principalest commodities and fruites of the earth, for that thereby they are inabled to bring all necessary things for the nourislyment and sustentation of man from the vttermost

1 Namely, the United Provinces of the Netherlands. 
partes of the world, and to carry and conuay such wares and marchendizes whereof they haue great store and aboundance vnto the same places, which As the art of by reason of the art of nauigation and nauigation more increas. eth, so there are daily more new countries found out. the commodities of the sea, is easily to be effected and brought to passe. IVhich nauigation as it dayly more and more increaseth (to the great woonder and admiration of those, that compare the sea-faring and navigation vsed in our forefathers' times, yea, and that also that hath beene practised in our age, with that which now Diligence and at this present is daily furthered and continuance effect that which is soughte. sought out), so there are continually new voiages made, and strange coasts discouered; the which although they be not done by the first, secōd, or third voiage, but after, by tract of time, first brought to their full effect, and desired commoditie, and the fruits thereby, by continuance of time reaped. Yet we

We must not leaue of by some men's dislike or dispraise in our proseedings. inust not be abasht, nor dismayed, at the labour, toile, trauaile, and dāgers sustayned in such uoiages, to that end made, although as I said before the benefit thereof be not had nor seene in the first, second, third, or nuore uoiages; for what labour is more profitable, and worthier praise and commendation, then that which tendeth vnto the common good and benefit of all men. . . .

W. Burents. 
(From The Seaman's Seirets)

$A$ ND sith nauigation is the meane whereby A countryes are discouered, and communitie drawne betweene nation and nation, the worde of God published to the blessed recouery of the forraine ofcastes from whence it hath pleased his diuine Maiestie as yet to detayne the brightnes of his glorie : and that by Nauigation commonweales through mutuall trade are not only susteined, but mightely enriched, with how great esteeme ought the painefull Seaman to be embraced by whose hard aduentures such excellent benefites are atcheiued, for by his exceeding great hazzards the forme of the earth, the quantities of Countries, the diuersitie of nations and the natures of Zones, Climats, Countries and people, are apparently made known vnto vs. Besides, the great benefites mutually interchanged betweene nations, of such fruits, commodities, and artificiall practises wherewith God hath blessed each particular country, coast and nation, according to the nature and situation of the place.

For what hath made the Spaniard to be so great a Monarch, the Commander of both Indias, to abound in wealth and all natures benefites, but only the painefull industrie of his Subiects by Nauigation. Their former trade was only figs, orenges, and oyle, but now through Nauigation is 
brought to be golde, siluer, pearles, silkes, and spice, by long and painefull trade recouered. Which great benefites onely by her Maiesties louing clemencie and merciful fauour he doth possesse : for if her highnes and her most honourable Lordes would not regard the small distance betweene her dominions and those famous rich Kingdomes, the easines of the passage being once discoured (the North-west I mean) with the full sufficience of her highnes Subiects to effect the same, there could then be no doubt, but her stately seate of London should bee the storehouse of Europe, and a nursse to all nations, in yeelding al Indian cómodities in a far better condition, and at a more easie rate then now brought unto vs, exchanging commoditics of our owne store, with a plentifull returne at the first hand, which now by many exchanges are brought vnto vs.

\section{John Daris, The Navigutor.}

\section{The Lateen Sail}

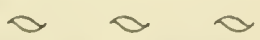

(From Esto Perpetua)

THERE is a sort of sail which may be called which antiquity was faniliar. It brought the slips to Tenedos and the Argo carried it. 'The Norwegians had it when they were pirates a thousand 
years ago. They have it still. It is nearer a lugsail than anything else, and indeed our Deal luggers carry something very near it. It is almost a square sail, but the yard has a slight rake and there is a bit of a peak to it. It is the kind of sail which seems to come first into the mind of any man when he sets out to use the wind. It is to be seen continually to-day hoisted above small boats in the north of Europe.

But this sail is too simple. It will not go close to the wind, and in those light and variable airs which somehow have no force along the deck, it hangs empty and makes no way because it has no height.

Now when during that great renaissance of theirs in the seventh century the Arabs left their deserts and took to the sea, they became for a short time in sailing, as in philosophy, the teachers of their new subjects. They took this sail, which they had found in all the ports they had conquered along this coast-in Alexandria, in Cyrene, in Carthage, in Cæsarea-they lightened and lengthened the yard, they lifted the peak up high, they clewed down the foot, and very soon they had that triangular lateen sail which will, perhaps, remain when every other evidence of their early conquering energy has disappeared. With such a sail they drove those first fleets of theirs which gave 
them at once the islands and the commerce of the Mediterranean. It was the sail which permitted their invasion of the northern shores and the unhappy subjection of Spain.

We Europeans have for now some seven hundred years, from at least the Third Crusade, so constantly used this gift of Islam that we half forget its origin. You may see it in all the Christian harbours of the Mediterranean to-day, in every port of the Portuguese coast, and here and there as far north as the Cliannel. It is not to be seen beyond Cherbourg, but in Cherbourg it is quite common....

... The little ships so rigged come out like heralds far from the coast to announce the old dominion of the East and of the religion that made them: of the united civilization that has launclied them over all its seas, from east of India to south of Zanzibar and right out here in the western place which we are so painfully recovering. They are the only made thing, the only form we accepted from the Arab: and we did well to accept it. The little ships are a delight.

You see them everywhere. They belong to the sea and they animate it. They are similar as waves are similar : they are different as waves atre different. They come into a hundred positions against the light. They heel and run with every mode of energy. 
'There is nothing makes a man's heart so buoyant as to see one of the little ships bowling along breasthigh towards him, with the wind and the clouds behind it, careering over the sea. It seems to have borrowed something of the air and something of the water, and to unite them both and to be their offspring and also their bond. When they are middle-way over the sea towards one under a good breeze, the little ships are things to remember.

So it is when they carry double sail and go, as we say of our schooners, "wing and wing." For they can carry two sails when the wind is moderate, and especially when the vessel is running before it ; but these two sails are not carried upon two masts, but both upon the same mast. The one is the common or working sail, carried in all weathers. The other is a sort of spinnaker, of which you may see the yard lying along decks in harbour or triced up a little by the halyard, so as to swing clear of the hands. When the little ships come up like this with either sail well out and square and their course laid straight before the general run of a fresh sea, rolling as they go, it is as though the wind had a friend and a companion of its own, understanding all its moods, so easily and rapidly do they arrive towards the shore. A little jib (along this coast at least) is bent along the forestay, and the dark line of it marks the 
swing and movement of the whole. So also when you stand and look from along their wake and see them leaving for the horizon along a slant of the Levantine, with the breeze just on their quarter and their laden hulls careening a trifle to leeward, you would say they were great birds, born of the sea, and sailing down the current from which they were bred. The peaks of their tall sails have a turn to them like the wing-tips of birds, especially of those darting birds which come up to us from the south after winter and shoot along their way. Moreover, the sails of these little ships never seem to lose the memory of power. Their curves and fulness always suggest a movement of the hull. Very often at sunset when the dead calm reflects things unbroken like an inland pond, the topmost angle of these lateens catches some hesitating air that stirs above, and leads it down the sail, so that a little ripple trembles round the bows of the boat, though all the water beside them is quite smooth, and you see her gliding in without oars. She comes along in front of the twilight, as gradual and silent as the evening, and seems to be inpelled by nothing more substantial than the advanre of darkness. It is with sucl companions to proclaim the title of the land that one comes round under a point of bills and enters harbour.

Hilitire Bclloc. 
The Modern Steamship

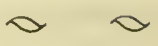

(From The Opal Sea)

$\mathrm{B}^{\mathrm{UT}}$ however much of actual beauty clings to a sail, and however much of traditional reverence bids us scorn an innovation, is there not something to be said for the grim, fire-spitting ocean steamer? In common with all steam devices the steamship has come in for a fair share of denunciation; but as a machine, as a resistless force, is there not something here to stir the pulses? As she sweeps down the harbour and out over the bar, flags streaming, black smoke trailing, wide wake rolling, what could be finer! She sits low down aft, she rises up keen and clean forward, her cutwater is as eager as a headsman's axe, her smoke-stacks have a slant astern as though ready for any wind or wave. What a sense of power is there! What can stop the passage of that dark conqueror! And she moves with no apparent effort. The source of power is not disclosed to the eye. Nor can the ear detect the beat of engines. The steel mass seems to be driven by a force as invisible as resistless.

No prayers to Oceanus, the parent of the gods, go up, when the ocean liner puts to sea. Eolus is not invoked for favourable winds, nor are the 
Tritons and Nereids put in good humour with promises and offerings. The ship of steel and steam seems to care little for the elements. The tremendous power in the engines carries her through wind and storm, through wave and spray. Nothing lialts or holds her for more than a moment. As the waters come rushing at her there is an easy bend and sway to the long body; she rises and falls, rolls quietly with a broadside, pitches sharply with a head sea; but there is no pause, no stop. The steady thrust of the screws keeps driving her ever on and on. Far away at sea her motion is still apparent, and finally when she is hull down beyond the rim, and only the black banner of smoke trailing along the horizon tells where she "blows," we still feel that she is moving, shouldering the waves away, pushing on and on; methodically, mechanically if you will, but still resistlessly.

The mechanism and the method become almost hunan in their stubborn perseverance when the vessel is steaming in storm against fierce head winds. 'There is the decp plunge of the bow in the waves, the alternate lift of the stem out of water, the swift racing of the exposed screws for a few moments; and then the setling down again to a steady thump-thump, thump-thump, thumpthump! The waves may board lier and break 
davits, bridges, and stanchions, she may pitch and roll till cabin and hold are a series of crashes and smashes, but those indomitable engines keep up their pulsations. You lie awake in the middle of the night clinging to your berth, hearing the whiplike swish of the spray flying by the port hole, listening to the roar of the wind in the rigging, feeling the vessel pitch and stagger under you, and perhaps wondering if rivets and plates of steel can long hold out against such wrenching; but still beneath you, skipping no beat, is the welcome thump-thump, thump-thump, thump-thump of the engines. She was designed to defy the winds and fight the elements and she does it-with some groanings from strained partition, beam, and girder it may be, but still she does it.

\section{J. C. Van Dyke.}

(From The Nirror of the Sea)

$A^{N D}$ besides, your modern ship, which is a A steamship, makes her passage on other principles than yielding to the weather and humouring the sea. She receives smashing blows, but she advances; it is a slogging fight, and not a scientific campaign. The machinery, the steel, the fire, the steam, have stepped in between the man and the sea. A modern fleet of ships does not so much make use of the sea as exploit a highway. The modern ship is not the sport of the waves. Let us 
say that each of her voyages is a triumphant progress; and yet it is a question whether it is not a more subtle and human triumph to be the sport of the waves and yet survive, achieving your end.

In his own time a man is always very modern. Whether the seaman of three hundred years hence will have the faculty of sympathy it is impossible to say. An incorrigible mankind hardens its heart in the progress of its own perfectability. How will they feel on seeing the illustrations to the sea novels of our day, or of our yesterday? It is impossible to guess. But the seaman of the last generation, brought into sympathy with the caravels of ancient time by his sailing ship, their lineal descendant, cannot look upon those lumbering forms navigating the naive seas of ancicnt woodcuts without a fccling of surprise, of affectionate derision, envy, and admiration. For those things, whose unmanagcableness, even when represented on paper, makes one gasp with a sort of amused horror, were manned by men who are his direct professional ancestors.

No; the scamen of threc hundred years hence will probably be neither touched nor moved to derision, affection, or admiration. They will glance at the plotogravures of our nearly defunct sailingships with a cold, inquisitive and indifferent eye. Our ships of yesterday will stand to their ships as no lineal ancestors, but as mere predecessors whose 
course will have been run and the race extinct. Whatever craft he handles with skill, the seaman of the future shall be, not our descendant, but only our successor.

\section{Joseph Conrall.}

(From Sull'Oceano)

NON m'era mai parso così bello il Galileo. Largo e poderoso ; ma le curve agili dei suoi fianchi e la grande lunghezza gli davan la grazia d'una gondola smisurata. I suoi alberi altissimi, congiunti come da una trama di cordami, parevano fusti di gigantesche palme diramate, legate da liane senza foglie, e le ampie bocche purpuree delle trombe a vento rendevan l'immagine di colossali calici di fiori, attirati dall'America invece che dal sole. I fianchi neri di catrame e severi, la coperta irta di ordigni di ferro e sorvolata da nuvoli di fumo oscuro; ma questo aspetto rude di vasta officina, rallegrato dalle lance azzurrine librate sui parapetti, dalle alte maniche a vento candide e gonfie, dai ponti mobili spiccanti nel cielo, da cento luccichii di metalli, di legni, di vetri, da mille oggetti e forme diverse e bizzarre, che rappresentano ciascuna una comoditì, un'eleganza, una difesa, un'industria, una forza. E il rumorio della macchina, $i$ colpi profondi del propulsore, le piattonate dell'elice, il cigolio delle catene del timone, il sibilo del solcometro, il fre- 
mito delle griselle, il tintinnio dei cristalli sospesi, formano una musica diffusa e strana, che accarezza l'orecchio ed entra nell'anima come un linguaggio misterioso di gente sparpagliata e invisibile, che a bassa voce s'inciti a vicenda al lavoro e alla lotta. La poppa sussulta sotto i nostri piedi come la carcassa d'un corpo vivo; il colosso ha guizzi improvisi, dei quali non si comprende la causa, e che paion tremiti di febbre, scatti bruschi e senza grazia, che paiono atti di dispetto, e mosse replicate di prua, che sembran gli scotimenti d'una enorme testa che pensi; e fila altre volte per lunghi tratti così fermo e pari sul nuare agitato, che una palla d'avorio non si moverebbe sulle sue tavole, c pare che non lambisca le onde. E va senza posa, nella nebiia, nelle tencbre, contro il vento, contro l'onda, con un popolo sul dorso, con cinquemila tonnellate nel ventrc, dall'uno all' altro mondo, guidato infallibilmente da una piccola spranghetta d'acciaio che può servire a tagliare $\mathrm{i}$ fogli d'un libro, e da un uomo che fa girare una ruota di legno con un leggero sforzo delle mani. Noi ricorriamo col pensiero la storia della navigazione, c risalendo dal tronco d'albero alla zattera, dalla piroga alla barca a remi, e su su per tutte le forme della nave ingrandite e furtificate clai secoli, ci fermiano dinanzi a quella forma ultima per raffrontarla alla prima, $e$ il cuore ci si gonfia d'ammirazione, e ci domandiamo quale altral opera 
meccanica più maravigliosa abbia compiuto la razza umana. Più maravigliosa dell'oceano che essa rompe e divora, e alla cui minaccia continua risponde collo strepito infaticato dei suoi congegni :-Tu sei immenso, ma sei un bruto; io son piccolo, ma sono un genio; tu separi i mondi, ma io li lego, tu mi circondi, ma io passo, tu sei strapotente, ma io so.

Edmondo de Amicis.

(From The Future in America)

F OR example, consider this last year's last word in ocean travel in which I am crossing, the Carmania, with its unparalleled steadfastness, its racing tireless great turbines, its vast population of 3244 souls! It has, on the whole, a tremendous effect of having come by fate and its own forces. One forgets that any one planned it, much of it indeed has so greatly the quality of moving, as the planets move, in the very nature of things. You go aft and see the wake tailing away across the blue ridges; you go forward and see the cleft water lift protestingly, roll back in an indignant crest, own itself beaten, and go pouring by in great foaming waves on either hand; you see nothing, you hear nothing of the toiling engines, the reeking stokers, the effort and the stress below; you beat west and west, as the sun does, and it might seem with nearly the same independence of any living 
man's help or opposition. Equally so does it seem this great gleaming confident thing of power and metal came inevitably out of the past, and will lead on to still more shining, still swifter and securer monsters in the future.

One sees in a perspective of history, first the little cockle-shells of Columbus, the comings and goings of the precarious Tudor adventurers, the slow uncertain shipping of colonial days. . . .

We're a city rather than a ship, our funnels go up over the height of any reasonable church spire, and you need walk the main deck from end to end and back only four times to do a mile. Any one who has been to London and seen Trafalgar Square will get our dinensions perfectly when he realizes that we should only squeeze into that finest site in Europe, diagronally, dwarfing the National Gallery, St. Martin's Church, hotels, and every other building there out of cxistence, our funncls towering five feet higher than Nelson on his column.

II. G. Hells.

Running Before the Wind

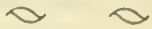

(From A Tarpaulin Mfuster)

WE were at sea off the River l'late, ruming south like a stag. The wind had been slowly freshening for twenty-four hours, and for one whole day we had whitened the sea like a battleship. 
Our run for the day had been $27 \mathrm{r}$ knots, which we thought a wonderful run, though it has, of course, been exceeded by many ships. For this ship it was an exceptional run. The wind was on the quarter, her best point of sailing, and there was enough wind for a glutton. Our captain had the reputation of being a "cracker-on," and on this occasion he drove her till she groaned. For that one wonderful day we staggered and swooped, and bounded in wild leaps, and burrowed down and shivered, and anon rose up shaking. The wind roared up aloft and boomed in the shrouds, and the sails bellied out as stiff as iron. We tore through the sea in great jumps-there is no other word for it. She seemed to leap clear from one green roaring ridge to come smashing down upon the next. I have been in a fast steamer-a very fast turbine steamer-doing more than twenty knots, but she gave me no sense of great speed. In this old sailing ship the joy of the hurry was such that we laughed and cried aloud. The noise of the wind booming, and the clack, clack, clack of the sheet-blocks, and the ridged seas roaring past us, and the groaning and whining of every block and plank, were like tunes for a dance. We seemed to be tearing through it at ninety miles an hour. Our wake whitened and brondened, and rushed away aft in a creamy fury. We were running here, and hurrying there, taking a small pull 
of this, and getting another inch of that, till we were weary. But as we hauled we sang and shouted. We were possessed of the spirits of the wind. WVe could have danced and killed each other. IVe were in an ecstasy. We were possessed. We half believed that the ship would leap from the waters and hurl herself into the heavens, like a winged god. Over her bows came the sprays in showers of sparkles. Her foresail was wet to the yard. Her scuppers were brooks. Her swing-ports spouted like cataracts. Recollect, too, that it was a day to make your heart glad. It was a clear day, a sunny day, a day of brightness and splendour. The sun was glorious in the sky. The sky was of a blue unspeakable. We were tearing along across a splendour of sea that made you sing. Far as one could see there was the water-shining and shaking. Bluc it was, and green it was, and of a dazzling brilliance in the sun. It rose up in hills and in ridges. It smashed into a foam and roared. It towered up again and toppled. It mounted and shook in a rhythm, in a tune, in a music. One could have flung one's body to it as a sacrifice. One longed to be in it, to be a part of it, to be beaten and banged by it. It was a wonder and a glory and a terror. It was a riumph, it was royal, to see that beauty.

John Miscfield. 


\section{A Day on the Ocean}

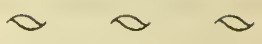

(From Captains Courageous)

THE low-sided schooner was naturally on most intimate terms with her surroundings. They saw little of the horizon save when she topped a swell; and usually she was elbowing, fidgeting, and coaxing her steadfast way through gray, grayblue, or black hollows laced across and across with streaks of shivering foam, or rubbing herself caressingly along the flank of some bigger waterhill. It was as if she said, "You wouldn't hurt me, surely? I'm only the little We're Here." Then she would slide away chuckling softly to herself till she was brought up by some fresh obstacle. The dullest of folk cannot see this kind of thing hour after hour through long days without noticing it ; and Harvey, being anything but dull, began to comprehend and enjoy the dry chorus of wavetops turning over with a sound of incessant tearing; the hurry of the winds working across open spaces and herding the purple-blue cloud shadows; the splendid upheaval of the red sunrise; the folding and packing away of the morning mists, wall after wall withdrawn across the white floors; the salty glare and blaze of noon; the kiss of rain falling over thousands of dead, flat square miles; the chilly blackening of everything at the day's end; 
and the million wrinkles of the sea under the moonlight, when the jib-boom solemnly poked at the low stars. ...

Rudyard Kipling.

\section{Pains of Early Sea Travel}

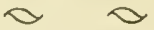

(From A First Voyage Round the World; Hakluyt Soc., trans.)

WEDNESDAY, the twenty-eighth of November, 1520, we came forth out of the said strait, and entered into the Pacific sea, where we remained three months and twenty days without taking in provisions or other refreshments, and we only ate old biscuit reduced to powder, and full of grubs, and stinking from the dirt which the rats had made on it when eating the good biscuit, and we drank water that was yellow and stinking. We also ate the ox hides which were under the mainyard, so that the yard should not break the rigging: they were very hard on account of the sun, rain, and wind, and we left them for four or five days in the sea, and then we put them a little on the embers, and so ate them; also the sawdust of wood, and rats which cost half-a-crown each, inoreover enough of them were not to be got. Besides the above-named evils, this misfortune which I will mention was the worst, it was that the upper and lower gums of most of our men grew so much that they could not eat, and in this way so 
many suffered, that nineteen died, and the other giant, and an Indian from the county of Verzin. Besides those who died, twenty-five or thirty fell ill of divers sicknesses, both in the arms and legs, and other places, in such manner that very few remained healthy. However, thanks be to the Lord, I had no sickness. During those three months and twenty days we went in an open sea, while we ran fully four thousand leagues in the Pacific sea. This was well named Pacific, for during this same time we met with no storm, and saw no land except two small uninhabited islands, in which we found only birds and trees. We named them the Unfortunate Islands; they are two hundred leagues apart from one another, and there is no place to anchor, as there is no bottom. There we saw many sharks, which are a kind of large fish which they call Tiburoni. The first isle is in fifteen degrees of austral latitude, and the other is in nine degrees. With the said wind we ran each day fifty or sixty leagues, or more; now with the wind astern, sometimes on a wind or otherwise. And if our Lord and his Mother had not aided us in giving us good weather to refresh ourselves with provisions and other things, we should all have died of liunger in this very vast sea, and I think that never man will undertake to perform such a royage.

Ferdinand Magellan. 
Charm of a Sea Voyage

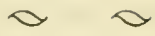

(From The Sketch Book)

I SAID that at sea all is vacancy; I should correct the expression. To one given to daydreaming, and fond of losing himself in reveries, a sea voyage is full of subjects of meditation; but then they are the wonders of the deep and of the air, and rather tend to abstract the mind from worldly themes. I delighted to loll over the quarter-railing, or climb to the main-top, of a calm day, and muse for hours together on the tranquil bosom of a summer's sea; to gaze upon the piles of golden clouds just peering above the horizon, fancy them some fairy realms, and people them with a creation of my own;-to watch the gentle undulating billows, rolling their silver volunies, as if to dic away on those happy shores.

There was a delicious sensation of mingled security and awe with which I looked down, from my giddy height, on the monsters of the deep at their uncouth gambols. Shoals of porpoises tumbling about the bow of the ship; the grampus slowly heaving his huge form above the surface; or the ravenous shark, darting, like a spectre, through the blue waters. My imagination would conjure up all that I had heard or read of the watery world beneath me; of the finny herds that 
roam its fathomless valleys; of the shapeless monsters that lurk among the very foundations of the earth; and of those wild phantasms that swell the tales of fishermen and sailors. ...

We one day descried some shapeless object drifting at a distance. At sea everything that breaks the monotony of the surrounding expanse attracts attention. It proved to be the mast of a ship that must have been completely wrecked, for there were remains of handkerchiefs by which some of the crew had fastened themselves to this spar, to prevent themselves being washed off by the waves. There was no trace by which the name of the ship could be ascertained. The wreck had evidently drifted about for many months; clusters of shellfish had fastened about it, and long seaweeds flaunted at its sides.

\section{Washington Irving.}

Life on Board Ship

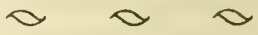

(From The Voyrage of H.M.S. "Beagle")

M ANY of the losses which must be experienced are obvious; such as that of the society of every old friend, and of the sight of those places with which every dearest remembrance is so intimately connected. These losses, however, are at the time partly relieved by the exhaustless delight of anticipating the long wished-for day of return. 
If, as poets say, life is a dream, I am sure in a voyage these are the visions which best serve to pass away the long night. Other losses, although not at first felt, tell heavily after a period: these are the want of room, of seclusion, of rest; the jading feeling of constant hurry; the privation of small luxuries, the loss of domestic society, and even of music and the other pleasures of imagination. When such trifles are mentioned, it is evident that the real grievances, excepting from accidents, of a sea-life are at an end. The short space of sixty years has made an astonishing difference in the facility of distant navigation. Even in the time of Cook, a man who left his fireside for such expechitions underwent severe privations. A yacht now, with every luxury of life, can circumnavigate the globe. Besides the vast inprovements in ships and naval resources, the whole western shores of America are thrown open, and Australia has become the capital of a rising continent. How different are the circumstances to a man shipwrecked at the present day in the Pacific, to what they were in the time of Cook! Since his voyage a liemisphere has been added to the civilised world.

If a person suffers much from sea-sickness, let him weigh it heavily in the latance. I speak from cxperience: it is no trifling cril, cured in a weck. 
If, on the other hand, he takes pleasure in naval tactics, he will assuredly have full scope for his taste. But it must be borne in mind how large a proportion of the time, during a long voyage, is spent on the water, as compared with the days in harbour. And what are the boasted glories of the illimitable ocean? A tedious waste, a desert of water, as the Arabian calls it. No doubt there are some delightful scenes. A moonlight night, with the clear heavens and the dark glittering sea, and the white sails filled by the soft air of a gentlyblowing trade-wind; a dead calm, with the heaving surface polished like a mirror, and all still except the occasional flapping of the canvas. It is well once to behold a squall with its rising arch and coming fury, or the heavy gale of wind and mountainous waves. I confess, however, my imagination had painted something more grand, more terrific, in the full-grown storm. It is an incomparably finer spectacle when beheld on shore, where the waving trees, the wild flight of the birds, the dark shadows and bright lights, the rushing of the torrents, all proclaim the strife of the unloosed elements. At sen the albatross and little petrel fly as if the storm were their proper sphere, the water rises and sinks as if fulfilling its usual task, the ship alone and its inhabitants seem the objects of wrath. On a forlorn and weatherbeaten coast the scene is indeed different, but the 
feelings partake more of horror than of wild delight.

Charles Darwin.

\section{The Channel Crossing}
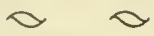

(From The Uncommercial Travelier)

THE wind blows stiffly from the Nor'-East, the sea runs high, we ship a deal of water, the night is dark and cold, and the shapeless passengers lie about in melancholy bundles, as if they were sorted out for the laundress; but for my own uncommercial part I cannot pretend that I am much inconvenienced by any of these things. A general howling, whistling, flopping, gurgling, and scooping, I am aware of, and a general knocking about of Nature; but the impressions I receive are very vaguc. In a sweet faint temper, something like the smell of damagred oranges, I think I should feel languidly benevolent if I had time. I have not timc, because $I$ am under a curious compulsion to occupy myself with the Irish melodies. "Rich and rare were the gems slie wore," is the particular melody to which I find myself deroted. I sing it to myself in the most charming manner and with the greatest expression. Now and then I raise my head (I ain sitting on the hardest of wet scats, in the most uncomfortable of wet attitudes, but I don't mind it), and notice that $I$ am a whirl- 
ing shuttlecock between a fiery battledore of a lighthouse on the French coast and a fiery battlcdore of a lighthouse on the English coast; but I don't notice it particularly, except to feel envenomed in my hatred of Calais. Then I go on again, "Rich and rare were the ge-ems she-e-e-e wore, And a bright gold ring on her wa-and she bo-ore, But $\mathrm{O}$ her beauty was fa-a-a-a-r beyond "I am particularly proud of my execution here, when I become aware of another awkward shock from the sea, and another protest from the funnel, and a fellow-creature at the paddle-box more audibly indisposed than I think he need be- "Her sparkling gems, or snow-white wand, But $\mathrm{O}$ her beauty was fa-a-a-a-a-r beyond"-another awkward one here, and the fellow-creature with umbrella down and picked up, "Her spa-a-rkling ge-ems, or her Port! port! steady! steady! snowwhite fellow-creature at the paddle-box very selfishly audible, bump roar wash white wand."

As my execution of the Irish melodies partakes of my imperfect perceptions of what is going on around me, so what is going on around me becomes something else than what it is. The stokers open the furnace doors below, to feed the fires, and I am again on the box of the old Exeter Telegraph fast coach, and that is the light of the for ever extinguished coach-lamps, and the gleam on 
the hatches and paddle-boxes is their gleam on cottages and hay'stacks, and the monotonous noise of the engines is the steady jingle of the splendid team. Anon, the intermittent funnel roar of protest at every violent roll, becomes the regular blast of a high pressure engine, and I recognise the exceedingly explosive steamer in which I ascended the Mississippi when the American civil war was not, and when only its causes were. A fragment of mast on which the light of a lantern falls, an end of rope, and a jerking block or so, become suggestive of Franconi's Circus at Paris where I shall be this very night mayhap (for it must be morning now), and they dance to the self-same time and tune as the trained steed, Black Raven. What may be the speciality of these waves as they come rushing on, I cannot desert the pressing demands made upon me by the gems she wore to inquire, but they are charged with something about Robinson Crusoe, and I think it was in Yarmouth Roads that he first went a-seafaring and was near founclering (what a terrific sound that word had for me when I was a boy!) in his first gale of wind. Still, through all this, I must ask her (who was she, I wonder!) for the fifticth time, and without ever stopping, Does she not fear to stray, So lone and lovely through this bleak way, And are Erin's sons so grood or so cold, As not to be tempted by more fellow-creatures at the paddle- 
box or gold? Sir Knight, I feel not the least alarm, No son of Erin will offer me harm, For though they love fellow-creature with umbrella down again and golden store, Sir Knight they what a tremendous one love honour and virtue more : For though they love Stewards with a bull's eye bright, they'll trouble you for your ticket, sirrough passage to-night!

I freely admit it to be a miserable piece of human weakness and inconsistency, but I no sooner became conscious of those last words from the steward than I began to soften towards Calais. Whereas I have been vindictively wishing that those Calais burghers who came out of their town by a short cut into the History of England, with those fatal ropes round their necks by which they have since been towed into so many cartoons, had all been hanged on the spot, I now begin to regard them as highly respectable and virtuous tradesmen. Looking about me, I see the light of Cape Grisnez well astern of the boat on the davits to leeward, and the light of Calais Harbour undeniably at its old tricks, but still ahead and shining. Sentiments of forgiveness of Calais, not to say of attachment to Calais, begin to expand my bosom. I have weak notions that I will stay there a day or two on my way back. A faded and recumbent stranger pausing in a profound reverie over the rim of a basin, asks me what kind of 
a place Calais is? I tell him (Heaven forgive me!) a very agreeable place indeed-rather hilly than otherwise.

So strangely goes the time, and on the whole so quickly-though still I seem to have been on board a week - that I am bumped, rolled, gurgled, washed, and pitched into Calais IIarbour before her maiden smile has finally lighted her through the Green Isle, When blest for ever is she who relied, On entering Calais at the top of the tide. For we have not to land to-night down among those slimy timbers-covered with green hair as if it were the mermaid's favourite combing-placewhere one crawls to the surface of the jetty, like a stranded shrimp, but we go steaming up the harbour to the Railway Station Quay. And as we go, she washes in and out among piles and planks, with dead heavy beats and in quite a furious manner (whereof we are proud), and the lamps shake in the wind, and the bells of Calais striking one seem to send their vilsrations struggling against troubled air, as we have come struggling against troubled water. And now, in the sudden relief and wiping of fices, everyloody on board scems to have had a prodigious double-tooth out, and to be this very instant free of the clentist's liands. And now we all know for the first time liow wet and cold we are, and how salt we are; and now I Inve Calais with my lieart of hearts! 
(From Jorrocks's Jaunts and Jollities)

NONE but the natives of Dover can tell what $N$ the weather is, unless the wind comes directly off the sea, and it was not until Mr. Jorrocks proceeded to embark, after breakfast the next morning, that he ascertained there was a heavy swell on, so quiet had the heights kept the gambols of Boreas. Three steamers were simmering into action on the London Hotel side of the harbour, in one of which - the Royal George-two britchkas and barouche were lashed ready for sea, while the custom-house porters were trundling barrows full of luggage under the personal superintendence of a little shock-headed French commissionaire of Mr. Wright's in a gold-laced cap, and the other gentry of the same profession from the different inns. ...

A voyage is to many people like taking an emetic-they look at the medicine and wish it well over, and look at the sea and wish themselves well over. Everything looked bright and gay at Dover -the cliffs seemed whiter than ever-the sailors had on clean trousers, and the few people that appeared in the streets were dressed in their Sunday best. The cart-horses were seen feeding leisurely on the hills, and there was a placid calmness about everything on shore, which the travellers would fain have extended to the sea. They 
came slowly and solemnly upon deck, muffled up in cloaks and coats, some with their passagemoney in their hands, and took their places apparently with the full expectation of being sick.

The French packet-boat first gave symptoms of animation, in the shape of a few vigorous puffs from the boiler, which were responded to by the Rojal George, whose rope was slipped without the usual tinkle of the bell, and she shot out to sea, closely followed by the Frenchman, who was succeeded by the other English boat. Three or four tremendous long protracted dives, each followed by a majestic rise on the bosom of the waves, denoted the crossing of the bar; and just as the creaking of the cordage, the flapping of the sails, and the nervous quivering of the paddles, as they lost their hold of the water, were in full vigour, the mate crossed the deck with a large white basin in his hand, the sight of which turned the stomachs of half the passengers. Who shall describe the misery that ensued? The groans and moans of the sufferers increasing every minute, as the vessel heaved and dived, and rolled and creaked, while hand-basins multiplied as half-sick passengers caught the green countenance and fixed eye of some prostrate sufferer, and were overcome themselves....

"Mew, mow," screamed the sea-gulls;-"crcak, crcak," went the cordage-"fop, flop," went the 
sails; round went the white basins, and the steward with the mop; and few passengers would have cared to have gone overboard, when at the end of three hours' misery, the captain proclaimed that they were running into still water off Boulogne.

\section{Robert Smith Surtees.}

The Atlantic Passage

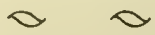

(From American Notes)

A HEAD-IVIND! Imagine a human face upon the vessel's prow, with fifteen thousand Samsons in one bent upon driving her back, and hitting her exactly between the eyes whenever she attempts to advance an inch. Imagine the ship herself, with every pulse and artery of her huge body swollen and bursting under this maltreatment, sworn to go on or die. Imagine the wind howling, the sea roaring, the rain beating: all in furious array against her. Picture the sky both dark and wild, and the clouds in fearful sympathy with the waves, making another ocean in the air. Add to all this, the clattering on deck and down below; the tread of hurried feet ; the loud hoarse shouts of seamen; the gurgling in and out of water through the scuppers; with, every now and then, the striking of a heavy sea upon the planks above, and the deep, dead, heavy sound of thunder heard within a 
vault; - and there is the head-wind of that January morning. . .

... But what the agitation of a steam-vessel is, on a bad winter's night in the wild Atlantic, it is impossible for the most vivid imagination to conceive. To say that she is flung down on her side in the waves, with her masts dipping into them, and that, springing up again, she rolls over on the other side, until a heavy sea strikes her with the noise of a hundred great guns, and hurls her back -that she stops, and staggers, and shivers, as though stunned, and then, with a violent throbping at her heart, darts onward like a monster goaded into madness, to be beaten down, and battered, and crushed, and leaped on by the angry sea-that thunder, lightning, hail, and rain, and wind, are all in fierce contention for the masterythat every plank has its groan, every nail its shriek, and every drop of water in the great ocean its how]ing voice-is nothing. To say that all is grand, and all appalling and horrible in the last degree, is nothing. Words cannot express it. Thoughts cannot convey it. Only a dream can call it up again, in all its fury, rage, and passion.

Charles Dickens. 
Leaving the Thames

(From The Other Side of the Lantern)

THE Thames creeps from under the fog, as if it came forth from a tunnel. Here at Tilbury it is a villainous tramp of a river. Dirty, sullen, and strong, it lurches down to the sea. It seems to revel in its dirtiness, for every eddy it turns up brings from the depths fresh realisations of a deeper dirt. It rubs its muddy shoulders along the shrinking banks, so that they are soiled by its touch. Mud and mist replace the glories of stream and sky. Where there may have been fields trodden by leisurely folk, with stiles for them to rest at and hedgerows for them to make love among, there are gullies and dykes of slime, a village of dismal sheds, and a spinney of cranes and derricks. The very grass, struggling up among ashes and rusting iron, looks lean and dissipated.

All this is the outcome of man's enterprise and industry. The huge, beery ogre of labour, dirty and sweating from his work, has thrown himself down in the lady's garden, and the lilies and the roses are crushed and sullied by his inconsiderate form.

In the background towards London there rises in the mist, beyond a palisade of masts, a forest of chimneys with foliage of smoke. Ships seem to be 
standing on dry land, and factories to be floating on the river. Spars and rigging, which have hummed with the bright wind of the Indies, hang over rows of callous houses. Here and there is a puff of red flame from a furnace door-a will o' the wisp in a mist of soot.

The stream would appear to come from a Purgatorio of labour, from some spectral workshop in which there is no rest from the dulness of eternal toil. Yet there is something about the place characteristic of England, of the obstinate energy of the race, and of its brutal disregard of all obstacles physical, moral, or asthetic when work is to be done or money is to be made.

The steamer swings at last towards the sea, and her long journey is begun. The chilled dock quay is deserted save to a few men who are languidly dragging in wet ropes, and a few others who are absorbed in what Stevenson calls that "richest form of idleness-hanging about harbour sides."

Sir IF. Treves.

\section{A Canoe at Sea}

(From 7he "Rob lioy" on the Jordan)

A T Alexandria once more we launched the liob liny to embark her on board the Deltu, bound for home. Farther out, and tossing in a gallant breeze, was the Ariulue frigate, the sea home of 
our Commodore, and of that fair Princess who has won from all Englishmen the hardest thing to win, our affectionate regard.

The waves tossed angry and boisterous as the Rob Roy ran out among the sharks to salute the Royal yacht.

The crew clustered thick in the rigging of the stately frigate, and cheered the tiny consort with goodwill.

"Turn round before the wind," they cried, "and show how you can go."

It was a moment both of pride and of fear to me: pricle in the craft that could finish such a voyage, and fear lest the finish was to be in a capsize. But the Rob Roy blithely turned upon a wave top and flew along the foam, and carried safe through all her little flag, and a heart that beat high with grateful praise to Him who had vouchsafed to me thus to enjoy one of the happiest days of a very happy life.

John Macgregor. 
VII

LIFE IN THE SEA 
We can scarcely poke or pry for an hour among the rocks, at low-water mark, or walk, with an observant downcast eye, along the beach after a gale, without finding some oddly-fashioned, suspicious-looking being, unlike any form of life that we have seen before. The dark concealed interior of the sea becomes thus invested with a fresh mystery; its vast recesses appear to be stored with all imaginable forms; and we are tempted to think there must be multitudes of living creatures whose very figure and structure have never yet been suspected.

Philip Gosse (from The Aquarium). 


\section{Variety of Types}
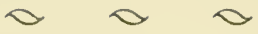

(From the Natural History ; trans.)

$\mathrm{BU}^{\mathrm{UT}}$ in the seas, spread out as they are far and wide, forming an element at once so delicate and so vivifying, and receiving the generating principles from the regions of the air, as they are ever produced by Nature, many animals are to be found, and indeed, most of those that are of monstrous form; from the fact, no doubt, that these seeds and first principles of being are so utterly conglomerated and so involved, the one with the other, from being whirled to and fro, now by the action of the winds and now by the waves. Hence it is that the vulgar notion may very possibly be true, that whatever is produced in any other department of Nature, is to be found in the sea as well; while, at the same time, many other productions are there to be found which nowhere else exist. That there are to be found in the sea the forms, not only of terrestial animals, but of inanimate objects even, is easily to be understood by all who will take the trouble to examine the grapefish, the sword-fish, the saw-fish, and the cucumberfish, which last so strongly resembles the real cucumber both in colour and in smell. We shall 
find the less reason, then, to be surprised to find that in so small an object as a shell-fish the head of the horse is to be seen protruding from the shell.

Pliny.

\section{Bonitoes and Flying Fish}

(From the Loyages)

THERE be also of sea fishes which wee sawe comming along the coast flying, which are of the bignesse of a smelt, the biggest sorte whereof haue four winges, but the other haue but two. Of these we sawe comming out of Guinea, a hundreth in a companie, which being chased by the Gilt heads, otherwise called the Bonitoes, doe to auoide them the better take their fight out of the water, but yet are they not able to flie farre, because of the drying of their winges, which serue them not to flye but when they are moyste, and therefore when they can flye no further fail into the water, and hauing wette their winges take a newe flight againe. These Bonitoes be of bignesse like a carpe, and in colour like a mackarell, but it is the swiftest fish in swimming that is, and followeth her praye very fiercely not onely in the water, but also out of the water: for as the flying fish taketh her flight, so doeth this Bonitoe leape after them, and taketh them sometime aboue the water. 
They were some of those Bonitoes, which being galled by a fisgig did follow our ship comming out of Guinea 500 leagues.

There is a sea foule also that chaseth this flying fish as wel as the Bonito: for as the flying fish taketh her flight, so doth this foule pursue to take her, which to beholde is a greater pleasure than hauking, for both the flights are as pleasant, and also more often then 100 times: for the foule can fie no way but one or other lighteth in her pawes, the nomber of them are so abundant. There is an innumerable yonge frie of these fying fishes which commonly keepe about the shippe, and are not so big as butterflies, and yet by flying doe auoyde the vnsatiablenesse of the Bonito. Of the bigger sort of these fishes, we tooke many, which both night and day flew into the sailes of our shippe, and there was not one of them which was not worth a Bonito: for being put vpon a hooke drabling in the water, the Bonito would leape thereat, and so was taken. Also, we tooke many with a white clothe made fast to a hooke, which being tied so short in the water, that it might leape out, and in, the greedie Bonito thinking it to be a flying fish leapeth thereat, and is deceiued. . . .

The manner of hunting and hawking representeth that which we reasonable creatures use, saving onely in the disposing of the grame. For by our industry and abilitic the hound and hawke is 
brought to that obedience, that whatever they seize is for their master: but here it is otherwise : for the game is for him that seizeth it: The dolphins and bonitoes are the houndes, and the alcatraces the hawkes, and the flying fishes the game; whose wonderfull making magnifieth the Creator, who for their safetie and helpe, hath given them extraordinary manner of fynnes, which serve in stead of wings, like those of the batt or reremouse; of such a delicate skinne, interlaced with small bones so curiously, as may well cause admiration in the beholders. They are like unto pilchards in colour, and making; saving that they are somewhat rounder, and (for the most part) bigger. They flie best with a side wind, but longer then their wings be wett they cannot sustaine the waight of their bodies; and so the greatest flight that I have seene them make, hath not beene above a quarter of a myle. They commonly goe in scoles, and serve for food for the greater fishes, or for the foules. The dolphins and bonitos doe continually hunt after them, and the alcatraces lye soaring in the ayre, to see when they spring, or take their flight; and ordinarily, he that escapeth the mouth of the dolphin or bonito, helping himselfe by his wings, falleth prisoner into the hands of the alcatrace, and helpeth to fill his gorge.

J. Hawkins. 
(From the Voyage; Ilakluyt Soc., trans.)

H ERE you see a strange quantity of fish, about as big as those called mullet, which have wings like bats, by means of which, when pursued by the larger fish, they dart out of the water and fly a long way until their wings are dry. So, on the other lland, when they are in the air, the sea birds, of which there is a vast multitude, give them chase and catch them, unless they first regain the sca. Many of them fell on our ships, and when once they fall on something hard where there is no water, they cannot raise themselves again. Thus we got some fresh fond (and much pleasure too in watching the chase), for this fish is delicate and good eating. But it was a marvellous sight to sec in so deep sea and in this quarter so vast a number of fish, that we might say we saw the whole sea covered with them, and all in a turmoil, though it was calm. There were also big ones, such as bonitos and albachores, and many other kinds, of which we caught with lines enough to supply the ship; and porpoises too, with harpoons attached to pieces of wood, then lifting them by strength of arm. I have seen these flying fish everywhere near the line, both on this and on the other side of the Cape of Good Hope, and both $\mathrm{N}$. and $\mathrm{S}$. of the line. 
(From $A$ Voyage to the East Indies; Hakluyt Soc., trans.)

$A$ BOUT that Iland and the Iland of Saint H Helena, unto the Equinoctiall line, there are flying Fishes, as great as Herings, which flie by great flockes together, two or three Fadome above the water, and flie in that manner at the least a quarter of a mile, untill their wings or finnes be drie, and then they can flie no longer, but fall into the water, and there wet themselves, and then flie againe above the water. The cause why they flie in that sort is, because they are chased by the great fishes, that eate them, and to escape from them, they flie above the water, and some times into the shippes: for many of them fell into our ship, which flew too high, for when their wings are drie they must needes fall.

Linschoten.

Mystery of the Ocean

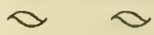

(From The Pirate)

THE ocean also had its mysteries, the effect of which was aided by the dim twilight, through which it was imperfectly seen for more than half the year. Its bottomless depths and secret caves contained, according to the account of Sweyn and 
others skilled in legendary lore, such wonders as modern navigators reject with disdain. In the quiet moonlight bay, where the waves came rippling to the shore, upon a bed of smooth sand intermingled with shells, the mermaid was still seen to glide along the waters by moonlight and, mingling her voice with the sighing breeze, was often heard to sing of subterranean wonders, or to chant prophecies of future events. The kraken, the hugest of living things, was still supposed to cumber the recesses of the Northern Ocean; and often, when some fog-bank covered the sea at a distance, the eye of the cxperienced boatman saw the horns of the monstrous leviathan walking and waving amidst the wreaths of mist, and borc away with all press of oar and sail, lest the sudden suction, occasioned by the sinking of the monstrous mass to the bottom, should drag within the grasp of its multifarious feelers his own frail skiff. The sea-snake was also known, which, arising out of the depths of ocean, stretches to the skies his enormous neck, covered with a nane like that of a war-horse, and, with his broad glittering eyes raised masthead high, looks out, as it seems, for plunder or for victims. 
Victory of the Coral-Builders

(From The Voy'age of H.M.S. "Beagle")

I CAN hardly explain the reason, but there is to my mind much grandeur in the view of the outer shores of these lagoon islands. There is a simplicity in the barrier-like beach, the margin of green bushes and tall cocoa-nuts, the solid flat of dead coral-rock, strewed here and there with great loose fragments, and the line of furious breakers, all rounding away towards either hand. The ocean, throwing its waters over the broad reef, appears an invincible, all-powerful enemy; yet we see it resisted, and even conquered, by means which at first seem most weak and inefficient. It is not that the ocean spares the rock of coral; the great fragments scattered over the reef, and heaped on the beach, whence the tall cocoa-nut springs, plainly bespeak the unrelenting power of the waves. Nor are any periods of repose granted. The long swell caused by the gentle but steady action of the trade-wind, always blowing in one direction over a wide area, causes breakers, almost equalling in force those during a gale of wind in the temperate regions, and which never cease to rage. It is impossible to behold these waves without feeling a conviction that an island, though built of the hardest rock, let it be porphyry, 
granite, or quartz, would uitimately yield and be demolished by such an irresistible power. Yet these low, insignificant coral-islets stand and are victorious; for here another power, as an antagonist, takes part in the contest. The organic forces separate the atoms of carbonate of lime, one by one, from the foaming breakers, and unite them into a symmetrical structure. Let the hurricane tear up its thousand huge fragments; yet what will that tell against the accumulated labours of myriads of architects at work night and day, month after month? Thus do we see the soft and gelatinous body of a polypus, through the agency of the vital laws, conquering the great mechanical power of the waves of an ocean which neither the art of man nor the inanimate works of nature could successfully resist.

Charles Daruin.

The Sea-Garden
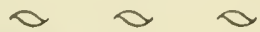

(From The Log of a Sea-Angler)

THE island of Santa Catalina is a picture with a which flows down our coast and has a frame of emerald green, the kelp beds; and with rare exceptions the entire I'acific coast is protected in this way, the giant weed rising in water thirty or more feet in height, reaclings the surface, and forming 
in many instances a barrier against the heavy sea which comes rolling in across the broad expanse of ocean. Especially at Santa Catalina it forms, in the smooth water of the north and east coasts, a series of beautiful floating gardens, twenty or more miles in extent; a forest of the sea of varied attractions, in which are found strange and often beautiful fishes, and other marine animals, specially adapted or modified by nature to their peculiar environment.

Midday, at half-tide, is the best time to visit these floating gardens; then the bottom can be plainly seen, a vivid turquoise blue gleaming brightly through the interstices of golden branches, really green, which, when illumined by the sun, take an old gold hue. The leaves are ten, twenty, or even thirty feet in length, twelve inches in width, richly fluted, and hang in myriad positions of grace and beauty, so that, in peering down from above, one looks through halls and parterres innumerable, that extend and reach away to infinity.

In South America, especially about the Falkland Islands, the kelp, or Macrocystis, attains an enormous length. Sections estimated at one thousand feet have been taken up and employed as cables for ships, which were thus saved the trouble of lowering and hoisting their anchors. On this desolate coast the kelp forms a protecting fringe for fishes, which otherwise would be unable to live, 
owing to the heavy surf that is always piling in ; and thus incidentally the miserable Patagonians are saved from starvation, subsisting almost entirely upon the fishes, the barren half-frozen land producing little or nothing.

Everywhere alongshore this maze of hardy vines constitutes a shelter for many animals. It is a forest of seaweed, rising from great depths, rolling over and over in strange but graceful convolutions in the surf or tidal currents, a menace to swimmers and at times to ressels, but, when dormant and illumined by the sun, a thing of radiant beauty.

Along the Santa Catalina coast, at extrene low tide, the kelp lies in such thick involved masses that it fornis an almost impassable barrier. These huge vines, which do not indicate a rocky coast, fasten to small rocks or stones anywhere in water of medium depth from a few yards to half a mile from shore; and, when cast up, show the sliort roots coiled about some small object with a vicelike grip. These floating gardens afford a home to a multitude of animals, strange, because they have insensibly taken on a singular means of protection, mimicking the tone or color of the leaf. These animals include cralıs, shell-less mollusks, and fishes. One of the crabs, which is nearly two inclies arross, is so perfect an imitation of the kelp that when lying directly before my eyes it was 
almost impossible to see it unless it moved. It has peculiar points and spikes which further intensify the resemblance. Lying on the great leaves are numbers of slug-like creatures, "shells" without shells, tinted green, safe in this protection from nearly all intruders. But the most remarkable resemblance is seen in a fish called the kelp fish. It is about a foot in length, the exact colour of the kelp, with a long continuous dorsal fin, frilled exactly like the edge of the leaf. Did this fish dart about, or comport itself as other fishes, it would at once be observed, but it does nothing of the kind; it lies at the bottom, or near it, standing literally upon its head, with its tail extending upward with the shorter kelp leaves, and in this position, hanging in the gardens, waves to and fro with every swell that sways the forest of algre.

\section{F. Holder.}

The Bottom of the Sea

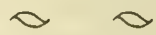

(From Vingt Mille Lieues sous les Mers)

UI! un taillis d'arbres morts, sans feuilles, sans séve, arbres minéralisés sous l'action des eaux, et que dominaient çà et là des pins gigantesques. C'était comme une houillère encore debout, tenant pars ses racines au sol effondré, et dont la ramure, à la manière des fines clécoupures 
de papier noir, se dessinait nettement sur le plafond des eaux. Que l'on se figure une forêt du Hartz, accrochée aux flancs d'une montagne, mais une forêt engloutie. Les sentiers étaient encombrés d'algues et de fucus, entre lesquels grouillait un monde de crustacés. J'allais, gravissant les rocs, enjambant les troncs étendus, brisant les lianes de mer qui se balançaient d'un arbre à l'autre, effarouchant les poissons qui volaient de branche en branche. Entrainé, je ne sentais plus la fatigue. Je suivais mon guide qui ne se fatiguait pas.

Quel spectacle! Comment le rendre? Comment peindre l'aspect de ces bois et de ces rochers dans ce milieu liquide, leurs dessous sombres et farouches, lcurs dessus colorés de tons rouges sous cette clarté que doublait la puissance réverbérante des eaux? Nous gravissions des rocs qui s'ćboulaient ensuite par pans énormes, avec un sourd grondement d'avalanche. A droite, ì grache, se creusaient de ténébreuses galeries où se perdait le regard. I ci s'ouvraient de vastes clairières, que la main de l'homme semblait avoir dégagécs, et je ine demandais parfois si quelque habitant de ces regions sous-marines n'allait pas tout à coup m’apparaître.

Mais le cajitaine Nemo montait toujours. Jc ne voulais pas rester en arriere. Je le suivais hardiment. Mon laton me prétait un utile secours. 
Un faux pas en̂t été dangereux sur ces étroites passes evidées aux flancs des gouffres; mais j'y marchais d'un pied ferme et sans ressentir l'ivresse du vertige. Tantôt je sautais une crevasse dont la profoncleur m'eût fait reculer au milieu des glaciers de la terre ; tantôt je m'aventurais sur le tronc vacillant des arbres jetés d'un abíme à l'autre, sans regarder sous mes pieds, n'ayant des yeux que pour admirer les sites sauvages de cette région. Là, des rocs monumentaux, penchant sur leurs bases irrégulièrement découpées, semblaient défier les lois de l'équilibre. Entre leurs genoux de pierre, des arbres poussaient comme un jet sous une pression formidable, et soutenaient ceux qui les soutenaient eux-mêmes. Puis, des tours naturelles, de larges pans taillés à pic comme des courtines, s'inclinaient sous un angle que les lois de la gravitation n'eussent pas autorisé à la surface des régions terrestres.

Et moi-mêne ne sentais-je pas cette différence due à la puissante densité de l'eau, quand, malgré mes lourds vêtements, ma tête de cuivre, mes semelles de métal, je m'élevais sur des pentes d'une impracticable raideur, les franchissant pour ainsi dire avec la légèreté d'un isard ou d'un chamois!

Au récit que je fais de cette excursion sous les eaux, je sens bien que je ne pourrai être vraisemblable! Je suis pourtant l'historien des choses d'apparence impossible, mais qui sont réelles, 
incontestables. Je n'ai point rêvé. J'ai ru et senti!

Deux heures après avoir quitté le Nautilus, nous avions franchi la ligne des arbres, et à cent pieds au-dessus de nos têtes se dressait le pic de la montagne dont la projection faisait ombre sur l'éclatante irradiation du versant opposé. Quelques arbrisseaux pétrifiés couraient çà et là en zigzags menaçants. Les poissons se levaient $\mathrm{en}$ masse sous nos pas comme des oiseaux surpris dans les hautes herbes. La masse rocheuse était creusée d'impénétrables anfractuosités, de grottes profondes, d'insondables trous, au fond desquels j'entendais remuer des choses formidables. Le sang me refluait iusqu'au coeur, quand j'apercevais unc antenne énorme qui me barrait la route, ou quelque pince effrayante se refermant avec bruit, dans l'ombre des cavités! Des milliers de points lumineux brillaient au milieu des ténèbres. C'étaient les yeux de crustacés gigantesques, tapis dans leur taniere, des homards géants se redressant comme des hallebardiers et remuant leurs pattes avec un cliquetis de ferraille, des crabes titanesques, braqués comme des canons sur leurs affuts, et des poulpes effroyables entrelaçant leurs tentacules, broussaille vivante de serpents.

Jules lerne. 
(From Three Cruises of the "Blake")

THE monotony, dreariness, and desolation of the deeper parts of this submarine scenery can scarcely be realised. The most barren terrestrial districts must seem diversified when compared with the vast expanse of ooze which covers the deeper parts of the ocean,-a monotony only relieved by the fall of the dead carcasses of pelagic animals and plants, which slowly find their way from the surface to the bottom, and supply the principal food for the scanty fauna found living there.

Nearer to the continental masses we find the slopes inhabited by a more abundant and more varied fauna, increasing in variety and numbers according to the amount of food available. But no matter how varied or how abundant life may be, the general aspect of the slopes must be dreary in the extreme, and can only be compared in character to those higher mountain regions where we find occasional fields of wild flowers and low shrubs, or to those zones lying beyond the limits of forests, where vegetation is scanty and poor and forms but a slight covering to the earth's surface.

It is true that along the continental slopes, where there is an ample supply of food, we find inimal life in great abundance, and there are un- 
doubtedly long stretches of bottom carpeted by the most brilliantly colored animals, packed quite as closely as they are on banks in shallower waters, or near low-water mark. But the scene is much less varied than on land ; the absence of plants in deep water makes great diversity of scenery impossible. The place of luxuriant forests with the accompanying underbrush and their inhabitants is only indifferently supplied by large anthozoa and huge cuttlefishes, or nearer in shore, within inoderate depths, by sea-weed and the pelagic forests of giant kelp.

It requires but little imagination to notice the contrasts, as we pass from the shallow littoral regions of the sea,-full of sunlight and movement, and teeming with animal and vegetable life, -into the dimly lighted, but richly populated continental zone; and further to imagine the gradual decrease of the continental fauna, as it fades into the calm, cold, dark, and nearly deserted abyssal regions of the oceanic floors at a distance from the continents. It is like going from the luxuriant vegetation of the tropical shore line-the region of palms, bananas, and mango-into the cooler zone of oaks and pines, until we pass out into the higher levels, with their stunted vegretation and scanty fauna, and finally into the colder climate of the bleak regions of perpetual snow.

Alexander Agassiz. 
(From $A$ Sack of Shakings)

$\mathrm{I}^{\mathrm{T}}$ would be an awful country to view, this suddenly exposed floor of the sea. A barren land of weird outline, of almost unimaginable complexity of contour, but without any beauty such as is bestowed upon the dry earth by the kindly sun. For its beauty depends upon the sea, whose prolific waters are peopled with life so abundantly that even the teeming earth is barren as compared with the ocean. But at its greatest depths all the rescarches that man has been able to prosecute go to prove that there is little life. The most that goes on there is a steady accumulation of the dead husks of once living organisms settling slowly down to form who knows what new granites, marbles, porphyries, against the time when another race of a reorganised earth shall need them. Here there is nothing fanciful, for if we know anything at all of prehistoric times, it is that what is now high land, not to say merely dry land, was once lying cold and dormant at the bottom of the sea, being prepared throughout who can say what unrealisable periods of time for the use and enjoyment of its present lords. Not until we leave the rayless gloom, the incalculable pressures and universal cold of those tremendous depths, do we find the sea-floor beginning to abound with life. It may even be doubted whether anything of man's handi- 
work, such as there is about a ship foundering in mid-ocean, would ever reach in a recognisable form the bottom of the sea at a depth of more than 2000 fathoms. There is an idea, popularly current among seafarers, that sunken ships in the deep sea only go down a certain distance, no matter what their build or how ponderous their cargo. Having reached a certain stratum, they then drift about, slowly disintegrating, derelicts of the depths, swarming with strange denizens, the shadowy fleets of the lost and loved and mourned.

\section{F. T. Bullen.}

Abundance of Fish in the Sea

(From the Joumal of a Vojrage 10 Lisbon)

OF all the animal foods with which man is furmished, there are none so plenty as fish. A litule rivulet, that glides almost unperceived through a vast tratct of rich land, will support more hundreds with the flesh of its inhabitants than the meadow will nourish inclividuals. But if this be true of rivers, it is much truer of the seashores, which abound with such immense variety of fish that the curious fisherman, after he hath matle his draught, often culis only the daintiest part and leaves the rest of his prey to perish on the shore.

If this be true, it would appeat, I think, that 
there is nothing which may be had in such abundance, and consequently so cheap, as fish, of which Nature seems to have provided such inexhaustible stores with some peculiar design. In the production of terrestrial animals she proceeds with such slowness that, in the larger kind, a single female seldom produces more than one a year, and this again requires three, four, or five years more to bring it to yerfection. And though the lesser quadrupeds, those of the wild kind particularly, with the birds, do multiply much faster, yet can none of these bear any proportion with the aquatic animals, of whom every female matrix is furnished with an annual offspring almost exceeding the power of numbers, and which, in many instances at least, a single year is capable of bringing to some degree of maturity. 
VIII

SEA FIGHTS 
"We gave her three pieces of ordnance only, and struck down her mizen mast, and then boarded sword in hand, but never had need to strike a blow; and before we left her, one of her own boys had changed her name, and re-christened her the "Cacaplata'."

"Glory, glory! Cowards they are, as I told thens. I told them they never could stand the Devon mastiffs!"

Charles Kingsley (from Westzuard Ho!). 
Salamis (48o B.C.)
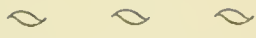

(From the History; Bohn, trans.)

WHEN the signal was given to the Greeks, first of all, turning their prows against the barbarians, they contracted their sterns inwardly to the middle; and when the second signal was given, they commenced the attack, though enclosed in a narrow space, and that prow to prow. On this occasion they took thirty ships of the barbarians, and Philaon, son of Chersis, the brother of Gorgus, king of the Salaminians, a man highly esteemed in their army. Lycomedes, son of Eschreus, an Athenian, was the first of the Grecks who took a ship from the enemy, and he received the palm of valour. But night, coming on, separated the combatants, who in this cngagement fought with doubtful success. The Greeks returned to Artemisium, and the barbarians to Apletx, having fought with far different success than they expected. In this engagement, Antidorus, a Lemnian, was the only one of the Greeks in the king's service who went over to the Crecians; and on that account the Athenians presented him with lands in Salamis.

When night came on-it was now tlue middle of summer-heavy rain fell through the whole night, 
and violent thunder about Pelion; but the dead bodies and pieces of wreck were driven to Aphetæ, and got entangled round the prows of the ships and impeded the blades of the oars. But the soldiers who were on board, when they heard the thunder, were seized with terror, expecting that they must certainly perish, into such calamities had they fallen. For before they had recovered breath, after the wreck and tempest that had occurred off Pelion, a fierce engagement followed ; and after the engagement, impetuous rain and mighty torrents rushing into the sea, and violent thunder. Such was the night to them. But to those who had been appointed to sail round Eubœa, this same night proved so much the more wild, in that it fell upon them while they were in the open sea; and the end was grievous to them; for as they were sailing, the storm and rain overtook them when they were near the Cœla of Eubœa, and, being driven by the wind, and not knowing where they were driven, they were dashed upon the rocks. All this was done by the deity, that the Persian might be brought to an equality with the Grecian, or at least not be greatly superior. Thus they perished near the Cœla of Eubœa. The barbarians at Aphetæ, when, to their great joy, day dawned, kept their ships at rest and were content, after they had suffered so much, to remain quiet for the present. But three-and-fifty 
Attic ships came to reinforce the Grecks; and both these by their arrival gave them additional courage, as did the news that came at the same time, that those of the barbarians who were sailing round Euboa had all perished in the late storm ; therefore, having waited to the same hour, they set sail and attacked the Cilician ships, and, having destroyed them, as soon as it was night they sailed back to Artemisium.

On the third day, the commanders of the barbarians, indignant at being insulted by so few ships, and fearing the displeasure of Nerxes, no longer waited for the Greeks to begin the battle; but, encouraging one another, got under weigh about the middle of the dlay. It happened that these actions by sea and those by land at Thermopylic took place on the same days; and the whole struggle for those at sea was for the Euripus, as for those with Leonidas to guard the pass. The one party encouraging each other not to suffer the barbarians to enter Greece; and the other, to destroy the Grecian forces and make themselves masters of the channel.

When the barbarians, having formed in line, sailed onwards, the Grecians remained still at Artemisium; but the barlsarians, having drawn up, their ships in the form of a crescent, encircled them as if they would take them; whereupon the 
Greeks sailed out to meet them, and engaged. In this battle they were nearly equal to one another; for the fleet of Xerxes, by reason of its magnitude and number, impcded itself, as the ships incommoded and ran foul of one another; however, they continued to fight and would not yield, for they were ashamed to be put to flight by a few ships. Accordingly many ships of the Grecians perished and many men; and of the barbarians a much greater number of both ships and men. Having fought in this manner, they separated from each other. In this engagement the Egyptians signalised themselves among the forces of Xerxes; for they both achieved other great actions and took five Grecian ships with their crews. On the part of the Greeks, the Athenians signalised themselves on this day, and, among the Athenians, Clinias, son of Alcibiades; who at his own expense joined the fleet with two hundred men and a ship of his own. ...

The barbarians being turned to fight, and sailing away towards Phalerus, the Eginitæ, waylaying them in the strait, performed actions worthy of record. For the Athenians in the rout ran down both those ships that resisted and those that fled; and the Eginitæ, those that sailed away from the battle: so that when any escaped, the Athenians, being borne violently on, they fell into the hands of the Æginitæ. At this time there happened to 
meet together the ship of Themistocles, giving chase to one of the enemy, and that of Polycritus, son of Crius, an Eginetan, bearing down upon a Sidonian ship, the same that had taken the Eginetan ship, which was kecping watch off Sciatius, and on board of which sailed Pytheas, son of Ischenous, whom, though covered with wounds, the Persians kept in the ship from admiration of his valour. The Sidonian ship that carried him about was taken with the Persians on board, so that Pytheas, by this means, returned safe to Agina. But when Polycritus saw the Athenian ship, he knew it, sceing the admiral's ensign ; and, shouting to Themistocles, he railed at him, upbraiding him with the charge of Medism brought against the Fininita. Polycritus accordingly, as he was attacking the ship, threw out these reproaches against Themistocles. But the barbarians, whose ships survived, fled and arrived at Plialerus, under the protection of the land forces....

When the sea-fight was ended, the Greeks, having hauled on slore at Salamis all the wrecks that still happened to be there, held themselves ready for another battle, expecting that the king would still make use of the ships that survived.

llerololus. 
(From The Persians; Bohn)

FOR a Greek that had come from the host of the Athenians told thy son Xerxes, this, that, when the gloom of murky night should come, the Greeks would not remain, but, springing on the benches of their vessels, would severally, in different directions, save their lives by stealthy flight. And he, as soon as he heard it, not aware of the stratagem of the Greek, nor of the jealousy of the gods, publishes this order to all his captains, that when the sun should have ceased to illumine the earth with his rays and darkness tenant the temple of the firmament, they should draw up the squadron of the ships in three lines, to guard the outlets and the murmuring passes of the sea, and others in a circle round the Isle of Ajax; so that if the Greeks should elude fatal destruction by discovering any escape for their ships by stealth, it was decreed that they should all be deprived of their heads. To this effect he spake from a frantic spirit; for he knew not that which was preordained of the gods. And they, without disorder, and with obedient mind, both provided supper for themselves, and the mariner lashed his oar to the well-fitted rowlock. And when the light of the sun had waned, and night 
had come on, every man, master of an oar, went on board his ship, and every one that had sway over arms: and one line of ships of war cheered on another line, and they made sail as each had been appointed, and all the live-long night the commanders of the ships were kecping the whole naval host occupied in sailing about. And night withdrew, and the force of the Greeks by no means made a stealthy escape in any direction. But when Day, drawn by white stecds, had occupicd the whole earth, of radiance beautiful to behold, first of all a shout from the Greeks greeted Echo like a song, and Echo from the island-rock at the same instant shouted forth an inspiring cry : and terror fell on all the barbarians, baulked of their purpose; for not as in flight were the Greeks, then chaunting the solemn pican, but speeding on to the fight with gallant daring of soul. And the trumpet, with its clang, inflamed their whole line; and forthwith, with the collision of the dashing oar, at the word of command they smote the roaring brine. And quickly were they conspicuous to view. The right wing, well marshalled, led on foremost in good order, and, secondly, their whole force was coming forth against us, and we could at the same time liear a mighty shout: SONS OF TIE GREFKS! (ON! IREK YOUR COUNTRY ANT) FREE, YOUK CIII,DIRE.N, YOUR WIVIS, THL AHOIMIS TOO OF TIE GOIS OF YOUR FATHEKS, ANI) TIIE 
TOMBS OF YOUR ANCESTORS; NOW IS THE CONFLICT FOR THEM ALL! And, sooth to say, a murmur of the Persian tongue met them from our line, and no longer was it the moment to delay, but forthwith ship dashed her brazen prow at ship. And a Grecian vessel commenced the engagement, and breaks off the whole of a figure-head of a Phœnician ship ; and each commander severally directed his bark against another of the enemy's. At first, indeed, the torrent of the Persian armament bore up against them: but when the multitude of our ships were crowded in the strait and no assistance could be given to one another, they were struck by their own brazen beaks and were smashing their entire equipment of oars, and the Grecian vessels, not without science, were smiting them in a circle on all sides, and the hulls of our vessels were upturned, and the sea was no longer to behold, filled as it was with wrecks and the slaughter of men. The shores, too, and the rugged rocks were filled with the dead; and every ship, as many as ever there were of the barbaric armament, was rowed in flight without order. But the Greeks kept striking, hacking us as it were tunnies, or any draught of fishes, with fragnents of oars and splinters of wrecks; and wailing filled the ocean brine with shrieks, until the eye of murky night removed it. But for the multitude of our woesno, not if I should recite them for ten days, could 
I complete the tale for thee. For be thou well assured of this, that there never fell in a single day a multitude of men of such number.

There is a certain island lying off the shores of Salamis, small, a dangerous station for ships, which I'an, who delights in the dance, haunts on its beach. Thither Xerxes sends these men, in order that, when the foemen, wandering out of their ships, should make their escape to the island, they might slay the soldiery of the Greeks, an easy prey, and rescue their comrades from the streams of the sea, ill knowing of the future; for when God gave the glory of the naval battle to the Greeks, on that very day having fortified their bodies in the armour well wrought of brass, they leaped out of their vessels and encompassed the whole island around, so that they were at a loss whither they should betake themselves; for often were they smitten by stones from their hands, and arrows, falling on them from the bowstring, destroyed them. And at last, having charged them with one onslaught, they smite, they hew in pieces the limbs of the wretches, until they liad utterly destroyed the life of all of them. And Xerxes shrieked aloud, when he saw the depth of his calamities; for he had a seat that afforded a clear prospect of the whole armament, a ligh hill near the ocean brine. 
Syracuse (B.C. 4I3)

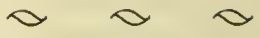

(From The History of the Peloponnesian War; Bohn, trans.)

THE Syracusans and their allies, having previously put out with pretty nearly the same number of ships as before, proceeded to keep guard with part of them at the passage out, and also round the circumference of the whole harbour, that they might fall upon the Athenians on all sides at once, while their troops also at the same time came to their aid at whatever part their vessels might put in to shore. The commanders of the Syracusan fleet were Sicanus and Agatharcus, each occupying a wing of the whole force, with Pythen and the Corinthians in the centre. When the Athenians came up to the bar, in the first rush with which they charged they got the better of the ships posted at it, and endeavoured to break the fastenings. Afterwards, when the Syracusans and their allies bore down upon them from all quarters, the engagement was going on no longer at the bar alone, but over the harbour also; and an obstinate one it was, such as none of the previous ones had been. For great eagerness for the attack was exhibited by the seamen on both sides, when the command was given; and there was much counter-manœuvring on the part of the masters, 
and rivalry with eacl other; while the soldiers on board exerted themselves, when vessel came in collision with vessel, that the operations on deck might not fall short of the skill shown by others. Indeed everyone, whatever the duty assigned him, made every effort that he might himself in each case appear the best man. And as a great number of ships were engaged in a small compass (for indeed they were the largest fighting flects in the narrowest space that had ever been known, since both of them together fell little short of two hundred), the attacks made with the beaks were few, as there was no means of backing water, or cutting through the enemy's line; but chance collisions were more frequent, just as one ship might happen to run into another, either in flying from or attacking a second. So long as a vessel was coming up to the charge, those on her decks plied their javelins, arrows, and stones in abundance against her; but when they came to close quarters, the heavy-armed marines, fighting hand to hand, endeavoured to board each others' ships. In many cases, too, it happened, throughts want of room, that on one side they were charging an enemy, and on the other were being charged themselves, and that two ships, and sometimes even more, were by compulsion entangled round one. And thus the masters liad to guard agrainst some, and to concert measures against others-not one 
thing at a time, but many things on every sidewhile the great din from such a number of ships coming into collision both spread dismay and prevented their hearing what the boatswains said. For many were the orders given and the shouts raised by those officers on each side, both in the discharge of their duty, and from their present eagerness for the battle: while they cried out to the Athenians "to force the passage," and now, if ever they meant to do it hereafter, to exert themselves heartily for a safe return to their country; and to the Syracusans and their allies, "that it would be a glorious achievement for them to prevent the enemy's escape, and by gaining the victory to confer honour on their respective countries." The commanders, moreover, on each side, if they saw any captain in any part unnecessarily rowing astern, called out on him by name and asked him, on the side of the Athenians, "whether they were retreating because they considered the land, which was in the possession of . their bitterest enemies, as more their own than the sea, which had been won with no small trouble?" on that of the Syracusans, "whether they were themselves flying from the flying Athenians, whom they knew for certain to be anxious to escape from them in any way whatever?"

The troops on shore, too, on both sides, when the sea-fight was so equally balanced, suffered a 
great agony and conflict of feelings; those of the country being ambitious now of still greater honour, while their invaders were afraid of faring even worse than at present. For, since the Athenians' all was staked on their fleet, their fear for the future was like none they had ever felt before; and from the unequal nature of the engagement they were also compelled to have an unequal view of it from the beach. . . .

After the battle had been thus obstinately disputed, and many ships and men destroyed on both sides, the Syracusans and allies, haring gained the victory, took up their wrecks and dead, and then sailed away to the city, and erected a tropliny. The Athenians, from the extent of their present misery, did not so much as think about their dead or their wrecks, or of asking permission to take them up, but wished to retreat immediately during the night. Demosthenes, however, went to Nicias, and expressed it as his opinion that they should still man their remaining ships, and force their passage out, if they could, in the morning; alleging that they still had left more ships fit for service than the enemy; for the Athenians had about sixty remaining, while their adversaries had less than fifty. But when Nicias agreed with this opinion, and they wished to man them, the seamen would not embark, through being dismayed at their defeat, and thinking that they could not now 
gain a victory. And so they all now made up their minds to retreat by land.

Thucydides.

Sluys (1340)
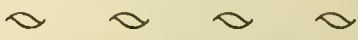

(From Chronicles)

THE French king being aduertised, that the king of England meant shortlie to returne into Flanders with a great power, in purpose to inuade the realme of France on that side, assembled a nauie of foure hundred ships vnder the leading of three expert capteins of the warres by sea, as sir Hugh Kiriell, sir Peter Bahuchet, and a Geneweis named Barbe Noir, appointing them to the coasts of Flanders to defend the king of England from landing there, if by any meanes they might. These three capteins or admerals came and laie with their ships in the hauen of Slujse, for that it was supposed the king of England would arriue there, as his meaning was indeed, wherevpon when his men, ships, and prouisions were once readie in the moneth of June, he tooke the sea with two hundred saile, and directing his course towards Flanders, there came vnto him the lord Robert Morley, with the north nauie of England, so that then he had in all about three hundred saile, or (as other saie) two hundred and three score. The French nauie laie betwixt Sluise and Blancbergh 
so that when the king of England approched, either part descried other, \& therewith prepared them to battell. The king of England staied, till the sunne which at the first was in his face, came somewhat westward, and so had it vpon his backe, that it should not hinder the sight of his people, and so therewith did set vpon his enimies with great manhood, who likewise verie stoutlie incountered him, by reason whereof insued a sore and deadlie fight betwixt them. The nauies on both sides were diuided into three battels. On the English part, the earles of Glocester, Northampton, and Huntington, who was admerall of the fleet that belonged to the cinque ports, and the lord Robert Morley, admerall of the northerne nauie, had the guiding of the foreward, bearing themselues right valiantlie, so that at length the Englishmen bauing the aduantage, not onlie of the sunne, but also of the wind and tide, so fortunatlie, that the rirencls fleet was driuen into the streights of the hauen, in such wise that neither the souldiers nor mariners could helpe themselves, in somuch that both heaten, sea, and wind secmed all to hate conspired agrainst the Frenchmen. And herewith manie ships of Flanrers ioining themselues with the linglish fleet, in the end the Frenchmen were vanquished, slaine and taken, their ships being also either taken bowged, or broken. 
When night was come vpon them, there were thirtie French ships, that yet had not entred the battell, the which sought by couert of the night to have stolne awaie, and one of them being a mightie great vessell, called the James of Deepe, would have taken awaie with hir a ship of Sandwich that belonged to the prior of Canturburie; bat by the helpe of the earle of Huntington, after they had fought all the night till the next morning, the Englishmen at length preuailed, and taking that great huge ship of Deepe, found in hir aboue foure hundred dead bodies. To conclude, verie few of the French ships escaped, except some of their smaller vessels, and certeine gallies with their admerall Barbenoir, who in the beginning of the battell got foorth of the hauen, aduising the other capteins to doo the like, thereby to auoid the danger which they wilfullie inbraced. There died in this battell fought (as some write) on midsummer daie, in the yeare aforesaid, of Frenchmen to the number of 30,000 , of Englishmen about 4000 , or (as other haue that liued in those daies) not past 400, amongst whom there were foure knights of great nobilitie, as sir Thomas Monhermere, sir Thomas Latimer, sir John Boteler, and sir Thomas Poinings.

It is said also, that the king himselfe was hurt in the thigh. The two English ships that had beene taken the yeere before, the Edward and the 
Christopher, were recouered at this time, amongst other of the French ships that were taken there. Sir Peter Bahuchet was hanged vpon a crosse pole fastened to a mast of one of the ships. Through the wilfulnesse of this man, the Frenchmen receiued this losse (as the French chronicles report) bicause he kept the nauie so long within the hauen, till they were so inclosed by the Englishmen, that a great number of the Frenchmen could neuer come to strike stroke, nor to vse the shot of their artillerie, but to the hurt of their fellows. Howsouer it was, the Englishmen got a famous victorie, to the great comfort of themselues, and discomfort of their aduersaries. The king of England, after he had thus vanquished his enimies, remained on the sea by the space of three daies, and then comming on land, went to Gant, where he was receiued of the queene with great ioy and gladnesse.

Holinshed.

Vasco da Gama engages the Calicut Fleet ( 1503 )

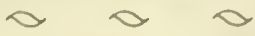

(From The Three l'oyages; Hakluyt Suc., trans.)

WHEN they had reached as far forward as the Moorish ships, all, recommending themselves to the Lord, discharged their guns, all firing at the flagship; and those which passed forward went 
against the other ships, for it was not possible to miss; and they made such haste to load again that they loaded the guns with bags of powder, which they had ready for this purpose made to measure, so that they could load again very speedily. I3ut with this first discharge our men made such good work that they brought down the mast of the flagship, which fell over and stove in the ship and killed many Moors; and another shot hit it full and passed through near the poop, which it shattered much and killed and wounded many people; of the other large ships three were stove in low down, so that they foundered and went to the bottom, many people remaining on the water swimming, who betook themselves to the paraos and caught hold of the oars, so that they could not row, and they could not get out of the way of their own ships, which came against them and capsized them, so that they so much embarrassed one another that they all remained stuck close to each other, and our ships fired into them for a considerable time, for they fired into the thick with their heavy guns, so that they shattered many in pieces, killing many people, on account of which there were shrieks and cries amongst the Moors. The ships brailed up their sails to the yards and discharged all their guns. The Moors, although they were in such straits, fired much artillery which they carried, and much of it threw shot like 
bowls, and they did not fight any other way. Thus embarrassed, the wind drove them out to sea, so that the ships lengthened their distance from them, always doing them much damage with the artillery, because our shot was much more powerful than theirs. As at this time the ships of burden had come up, Vicente Sodré loosed his sails and ran on after the caravels, which were now reaching the other squadron of the Moors, the captain of which was the Moor Coja Kasim, which consisted of more than a hundred sail, but the greater part of them were sambuks, which he had collected to make a show of a great fleet ; and these, seeing the ships and caravels coming, as they left the others already routed, were greatly afraid. But the Moor held on his course with all his large slips straight for our ships to board them, and Vicente Sodré did not turn aside because he went with all his artillery ready, and Ruy Lorenzo Kavasco and Vasco liernandes 'Tinoco, who were in the other ships, also went prepared. As the wind freshened and was better for our ships, they made straight for the Moorish fagship which came foremust and in the centre of the others, and luefore closing there was a discharge of many shot; and as the fagship carried much artillery, one shot entered the ship of Vasco 'Tinoco, and killed him and two men, wounding rothers with splinters of wood, lut a shot from the l'ortuguese ship took the flagship 
obliquely and threw it into disorder, killing many men, because all the Moors showed themselves above, but our men remained below, and none showed except the gunners and the men who assisted them. The Portuguese ships kept their steerage way, keeping aloof from the Moorish ships, passing amongst them all, doing wonders with their artillery, firing both broadsides and their poop and forecastle guns, as in all directions it was not possible to miss; the Moors also fired much artillery which they carried, but they were small guns, and when they passed near our ships they covered them with arrows, but they did not hurt the men, who lay hid, and so they passed through all the fleet of the Moors, and when they had passed the ships and sails were covered with arrows, and there were many holes in the sails and much rigging broken; but the Moorish ships were much ill-treated, they were shattered and stove in, and many had the masts and yards shattered, which was the greatest advantage our men obtained.

Vasco da Gama. 
Lepanto $\left(\mathrm{r}_{57} \mathrm{r}\right) \propto \curvearrowright$

(From The Rise of the Dutch Republic)

SIX hundred vessels of war met face to face. Rarely in history had so gorgeous a scene of martial array been witmessed. An October sun gilded the thousand beauties of an Ionian landscape. Athens and Curinth were behind the combatants, the momntains of Alexander's Macedon rose in the distance; the rock of Sappho and the heights of Actium were before their eyes. Since the day when the world had been lost and won beneath that famous promontory, no such combat as the one now approaching had been fought upon the waves. 'The chivalrous young commander despatched energetic messages to his fellow chicf. tains, and now that it was no longer possible to clude the encounter, the martial ardor of the allies was kindled. The Venetian High-Admiral replied with words of euthusiasm. Colonna, licutenamt of the league, answered his chief in the language of Saint Peter: "Though I die, yet will I not deny thee."

The fleet was arranged in three divisions. The Ottomans, not drawn up in crescent form, as usual, had the same triple disposition. Barbarigo and the other V'enctians commanded on the left, John 
Andrew Doria on the right, while Don John himself and Colonna were in the centre. Crucifix in hand, the High-Admiral rowed from ship to ship, exhorting generals and soldiers to show themselves worthy of a cause which he had persuaded himself was holy. Fired by his eloquence and by the sight of the enemy, his hearers answered with eager shouts, while Don John returned to his ship, knelt upon the quarter-deck, and offered a prayer. $\mathrm{He}$ then ordered the trumpets to sound the assault, commanded his sailing-master to lay him alongside the Turkish Admiral, and the battle began. The Venctians, who were first attacked, destroyed ship after ship of their assailants after a close and obstinate contest, but Barbarigo fell dead ere the sunset, with an arrow through his brain. Meantime the action, immediately after the first onset, had become general. From noon till evening the battle raged, with a carnage rarely recorded in history. Don Jolnn's own ship lay yard-arm and yard-arm with the Turkish Admiral, and exposed to the fire of seven large vessels besides. It was a day when personal audacity, not skilful tactics, was demanded, and the imperial bastard showed the metal he was made of. The Turkish Admiral's ship was destroyed, his head exposed from Don John's deck upon a pike, and the trophy became the signal for a general panic and a complete victory. By sunset the battle had been won. 
Of nearly threc hundred Turkish galleys, but fifty made their escape. From twenty-five to thirty thousand Turks were slain, and perhaps ten thousand Christians. The galley-slaves on both sides fought well, and the only beneficial result of the victory was the liberation of several thousand Christian captives. It is true that their liberty was purchased with the lives of a nearly equal number of Christian soldiers, and by the reduction to slavery of almost as many thousand Mussulmen, duly distributed among the Christian victors. Many causes contributed to this splendid triumph. The Turkish ships, inferior in number, were also worse manned than those of their adversarics, and their men were worse armed. Every bullet of the Christians told on muslin turbans and embroidered tunics, while the arrows of the Moslems fell harmless on the casques and corslets of their foes. The 'lurks, too, had committed the fatal error of fight. ing upon a lee shore. Having no sea room, and being repelled in their first onset, many galleys were driven upon the rocks, to be destroyed with all their crews.

John lothrop Motlcy. 
The Spanish Armada ( $5^{8 S)}$

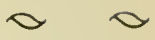
(From The History of England)

A LL being thus in order, the Prince of Parma ready to embark, the paternal admonition to the English nation to commit treason prepared for circulation, and the last touches added to the completeness of the fleet in the Tagus, the Duke of Medina Sidonia sailed from Lisbon on the igth-29th of May. The northerly breeze which prevails on the coast of Portugal was unusually strong. The galleons standing high out of the water, and carrying small canvas in proportion to their size, worked badly to windward. They were three weeks in reaching Finisterre, where, the wind having freshened to a gale, they were scattered, some standing out to sea, some into the Bay of Biscay. Their orders, in the event of such a casualty, had been to make for Ferrol. The wind shifting suddenly to the west, those that had gone into the Bay could not immediately reach it, and were driven into Santancler. The officers, however, were, on the whole, well satisfied with the qualities which the ships had displayed. A mast or two had been sprung, a few yards and bowsprits had been carried away; but beyond loss of time there had been no serious damage.

The weather moderating, the fleet was again 
collected in the Bay of Ferrol by the 6th-16th of July. All repairs were completed by the I ith-2 Ist, and the next day, the I2th-22nd, the Armada took leave of Spain for the last time.

The scene as the fleet passed out of the harbour must have been singularly beautiful. It was a treacherous interval of real summer. The early sun was lighting the long chain of the Gallician mountains, marking with shadows the cleft defiles, and shining softly on the white walls and vineyards of Coruña. The wind was light, and falling towards a calm; the great galleons drifted slowly with the tide on the purple water, the long streamers trailing from the trucks, the red crosses, the emblem of the crusade, shewing bright upon the hanging sails. The fruit boats were bringing off the last fresh supplies, and the pinnaces hastening to the ships with the last loiterers on shore. Out of thirty thousand men who that morning stood upon the decks of the proud Armadi, twenty thousand and more were never again to see the hilis of Spain. Of the remnant who in two short months crept back ragged and torn, all but a few hundreds returned only to dic.

The Spaniards, though a great people, were usually over conscious of their greatness, and boasted too loudly of their fame and prowess; but among the soldiers and sailors of the doomed expedition against England, the national rain- 
glory was singularly silent. They were the flower of the country, called and chosen over the entire Peninsula, and they were going with a modest nobility upon a service which they knew to be dangerous, but which they believed to be peculiarly sacred. Every one, scaman, officer, and soldier, had confessed and communicated before he went on board. Gambling, swearing, profane language of all kinds had been peremptorily forbidden. Private quarrels and differences had been made up or suspended. The loose women who accompanied Spanish armies, and sometimes Spanish ships to sea, had been ordered away, and no unclean thing or person permitted to defile the Armada; and in every vessel, and in the whole fleet, the strictest order was prescribed and observed. Medina Sidonia led the way in the San Martin, showing lights at night, and firing guns when the weather was hazy. Mount's Bay was to be the next place of rendezvous if they were again scparated.

On the first evening the wind dropped to a calm. The morning after, the 13 th-23rd, a fair fresh breeze came up from the south and south-west; the ships ran flowingly before it ; and in two days and nights they had crossed the bay, and were off Ushant. The fastest of the pinnaces was dispatched from thence to Parma, with a letter bidding him cxpect the Duke's inmediate coming. 
But they had now entered the latitude of the storms which through the whole season had raged round the English shore. The same night a south-west galc overtook them. They lay-to, not daring to run further. The four galleys unable to keep the sea were driven in upon the French coast, and wrecked. The Santa Aña, a galleon of eight hundred tons, went down, carrying with her ninety seamen, three hundred soldiers, and fifty thousand ducats in gold. The weather was believed to be under the peculiar care of God, and this first misfortune was of evil omen for the future. The storm lasted two days, and then the sky cleared, and, again gathering into order, they proceeded on their way. On the igth-29th they were in the mouth of the Channel. At daybreak on the morning of the 2oth-3oth the I.izard was under their lec, and an English fishing boat was hanging near them, counting their numbers. They grave chase; but the boat shot away down wind and clisappeared. They captured another an hour or two later, from which they learnt the English flect was in l'lymouth, and Meclina Sidomia called a council of war, to consider whether they shoukl go in, and fall upon it while at anchor. I'hilip's orclers, however, were perenptory thiat they should turn neitler right nor left, and make straight for Margate rnacls and l'aruat. The Duke was uncuterprising, and conseriously un- 
equal to his work; and already bending under his responsibilities he hesitated to add to them.

Had he decided otherwise it would have made no difference, for the opportunity was not allowed him. Long before the Spaniards saw the Lizard they had themselves been seen, and on the evening of the Igth-2gth, the beacons along the coast had told England that the hour of its trial had come. . . .

. . Again a council was held. The sickness had become frightful. Those who had escaped unwounded were falling ill from want and cold, and the wounded were dying by hundreds, the incessant storms making care and attention impossible. Calderon and the French pilot insisted that at all costs and hazards they must keep off the Irish coast. Diego Florez, distressed for the misery of the men, to whose sufferings want of water had become a fearful aggravation, imagined that along the west shore there must be a harbour somewhere; and that they would find rest and shelter among a hospitable Catholic people. The Bishop of Killaloe, a young Fitzmaurice, and a number of Irish friars were in the fleet. Diego Florcz had possibly heard them speak of their country and countrymen, and there were fishing conncxions between Cadiz and Valencia and Galway, which he and many others must have 
known of, though they had not been on the coast in person. But the lrish themselves were with Alonzo da Leyva, and Siclonia happily took the opinion of the pilots. The day was fine and the sick were divided; those which could be moved were transferred wherever there was most room for them, and as Calderon passed to and fro among the galleons with his medicines and his arrowroot, he was received everywhere with the eager question, where was Alonzo da Leyva? There was scarcely a man who did not forget his own wretchedness in anxicty for the idol of them all.

The calm had been but an interlude in the storm. The same night the wild west wind came down once more, and for eleven consecutive days they went on in their misery, unable to communicate except by signals, holding to the ocean as far as their sailing powers would let them, and seeing galleon after gralleon, Oquendos among them, falling away to leeward amidst driving squalls and rain, on the vast rollers of the Atlantic. An island which he supposed to be ten leagues from the coast, Calderon passed dangerously near. It was perhaps Achill, whose remendous cliffs fall sheer wo thousand fect into the seat, or perhaps Innisbofin or Innisharl. On the 4 th-1fth of September, he, with Sidonia and fifty vessels, fiftytwo ships unly out of a hundred and fifty, leaking 
through every seam, and their weary crews ready to lie down and die from exhaustion, crawled past the Blaskets, and were out of danger. . . .

. . Another galleon of a thousand tons, named Our Lady of the Rosary, which Calderon had watched sadly falling away before the waves, had also nearly weathered the headland of Kerry. She had all but escaped. Clear of the enormous cliffs of the Blasket Islands, she had no more to fear from the sea. Between the Blaskets and the mainland there is a passage which is safe in moderate weather, but the gale, which had slightly moderated, had risen again. The waves as they roll in from the Atlantic on the shallowing shores of 1 reland boil among the rocks in bad weather with a fury unsurpassed in any part of the ocean. Strong tidal currents add to the danger, and when Our Ladly of the Rosary entered the sound, it was a cauldron of boiling foam. There were scarcely hands to work the sails. Out of seven hundred, five hundred were dead, and most of the survivors were gentlemen, and before she was half-way through, she struck among the breakers upon the island. A maddened officer ran the pilot (a Genoese) through the heart, saying he had done it by 'treason.' Some of the gentlemen tried to launch a boat, but no boat could live for a moment in such a sea. The pilot's son lashed himself to a 
plank, and was washed on shore alone of the whole company, and all the rest lay among cannon and doubloon chests amidst the rocks in Blasket Sound. . . .

. . Such was the fate of the brilliant chivalry of Spain ; the choicest representatives of the most illustrious families in Europe. They had rushed into the service with an emotion pure and generous as ever Templar to the Sepulchre of Christ. 'They believed that they were the soldiers of the Almighty. Pope and Bishop had commended them to the charge of the angels and the saints. The spell of the names of the Apostles had been sliattered by English cannon. The elements, which were decmed God's peculiar province-as if to disenchant Christendom, were disenchantment possible, of so fond an illusion-whirled them upon a shore which the waves of a hundred million years had made the most dangerous in the world; there, as they crawled half drowned through the surf, to fall into the jaws of the Irish wolves.

Jimes Anthony Finule. 
Death of Sir Richard Grenville

(From the Voyage to the East Indies; Hakluyt Soc., trans.)

THE 13. of September the saide Armado arived at the Iland of Corno, where the Englishmen with about sixteene shippes as then lay, staying for the Spanish Fleete ; whercof some of the most parte were come, and there the English were in good hope to have taken them. But when they perceyved the King's Army to be strong, the Admirall being the Lorde Thomas Howard, commaunded his Fleete not to fall upon them, nor any of them once to separate their shippes from him, unlesse he gave commission so to doe; notwithstanding the Vice Admirall Sir Rychard Greenfield ${ }^{1}$ being in the ship called the Revenge went into the Spanish fleete, and shot among them, doing them great hurte, and thinking the rest of the company would have followed: which they did not, but left him there, and sayled away: the cause why could not be knowne; which the Spaniardes perceiving, with seven or eight shippes they borded her, but she withstood them all, fighting with them at the least 12 . houres together, and sunk two of them, one being a newe double Flie boat, of 12,000 tunnes, and Admirall of the Flie

1 Read "Greenville." 
boates, the other a Biscaine: But in the ende by reason of the number that came uppon her she was taken, but to their great losse: for they had lost in fighting, and by drowning above 400 . men, and of the English were slaine about a hundred, Sir Rychard Greenfield himselfe being wounded in his braine, whereof afterwarls hee dyed. He was borne into the ship called the Saint Paule, wherein was the Admirall of the fleet Don Alonso de Barsan': there his woundes were drest by the Spanish Surgeons, but Don Alonso himselfe would neither sce him, nor speake with him: all the rest of the Captaines and Gentlemen went to visite him, and to comfort him in his hard fortune, wondring at his courage, and stout heart, for that he shewed not any signe of faintnes nor changing of colour. But feeling the hower of death to approch, hee spake these wordes in Spanish, [\& said]: Here die I Richard Grecnfield, with a ioyfull and quiet mind, for that I have encled my life as a true soldier ought to do, yt. hath fought for his countrey, Quecne, religion, and honor, whereby my soule most ioyfull departeth out of this bodie, and shall alwaies leave behinde it an everlasting fame of a valiant and true soldier, that hath done his dutie, as he was bound to doe. When he had finished these [or such other like] words, hee grave up the Ghost, with great and stont courage, and

'Rearl "Basnn." 
no man could perceive any true signe of heavinesse in him.

\section{Linschoten.}

\section{La Hogue (1692)}
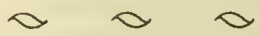

(From The History of England)

TOURVILLE had with him only his own squadron, consisting of forty-four ships of the line. But he had received positive orders to protect the descent on England, and not to decline a battle. Though these orders had been given before it was known at Versailles that the Dutch and English fleets had joined, he was not disposed to take on himself the responsibility of disobedience. He still remembered with bitterness the reprimand which his extreme caution had drawn upon him after the fight of Beachy Head. He would not again be told that he was a timid and unenterprising commander, that he had no courage but the vulgar courage of a common sailor. He was also persuaded that the odds against him were rather apparent than real. He believed, on the authority of James and Melfort, that the English seamen, from the flag officers down to the cabin boys, were Jacobites. Those who fought would fight with half a heart; and there would probably be numerous desertions at the most critical moment. Animated by such hopes he sailed from Brest, 
steered first towards the north-east, came in sight of the coast of Dorsetshire, and then struck across the Channel towards La Hogue, where the arnıy which he was to convoy to England had already begun to embark on board of the transports. He was within a few leagues of Bartleur when, before sunrise on the morning of the nineteenth of May, he saw the great armament of the allies stretching along the eastern horizon. He determined to bear down on them. By eight the two lines of battle were formed; but it was eleven before the firing began. It soon became plain that the English, from the Admiral downwards, were resolved to do their duty. Russell had visited all his ships, and exhorted all his crews. "If your commanders play false," he said, "overboard with them, and with myself the first." There was no defection. There was no slackness. Carter was the first who broke the French line. He was struck by a splinter of one of his own yardarms, and fell dying on the deck. He would not be carried below. He would not let go his sword. "light the ship," were his last words: "fight the ship as long as she can swim." "The battle lasted till four in the afternoun. The roar of the guns was distinctly heard more than twenty miles off by the army which was encamped on the coast of Normandy. During the earlier part of the day the wind was favourable to the French: they were 
opposed to only half of the allied fleet; and against that half they maintained the conflict with their usual courage and with more than their usual seamanship. After a hard and doubtful fight of five hours, Tourville thought that enough had been done to maintain the honour of the white flag, and began to draw off. But by this time the wind had veered, and was with the allies. They were now able to avail themselves of their great superiority of force. They came on fast. The retreat of the French became a fight. Tourville fought his own ship desperately. She was named, in allusion to Lewis's favourite emblem, the Royal Sun, and was widely renowned as the finest vessel in the world. It was reported among the English sailors that she was adorned with an image of the Great King, and that he appeared there, as he appeared in the Place of Victories, with vanquished nations in chains beneath his feet. The gallant ship, surrounded by enemies, lay like a great fortress on the sea, scattering death on every side from her hundred and four portholes. She was so formidably manned that all attempts to board her failed. Long after sunset, she got clear of her assailants, and, with all her scuppers spouting blood, made for the coast of Normandy. She had suffered so much that Tourville hastily removed his flag to a ship of ninety guns which was named the Ambitious. By this time his fleet was scattered 
far over the sea. About twenty of his smallest ships made their escape by a road which was too perilous for any courage but the courage of despair. In the double darkness of night and of a thick sea fog, they ran, with all their sails spread, through the boiling waves and treacherous rocks of the Race of Alderney, and, by a strange good fortune, arrived without a single disaster at Saint Maloes. The pursuers did not venture to follow the fugitives into that terrible strait, the place of innumerable shipwrecks. . . .

. . Russell meanwhile was preparing for an attack. On the afternoon of the twenty-third of May all was ready. A flotilla consisting of sloops, of fireships, and of two hundred boats, was entrusted to the command of Rooke. The whole armament was in the higlest spirits. The rowers, fushed by success, and animated by the thought that they were going to fight under the eyes of the French and lrish troops who had been assembled for the purpose of subjugating lingland, pulled manfully and with loud huzas towards the six huge worden castles which lay close to fort Lisset. The French, though an eminently brave people, have always been more liable to sudden panics than their phlegmatic neighbours, the English and Gernans. On this day there was a panic both in the flect and in the army. Tourville 
ordered his sailors to man their boats, and would have led them to encounter the enemy in the bay. But his example and his exhortations were vain. His boats turned round and fled in confusion. The ships were abandoned. The cannonade from Fort Lisset was so feeble and ill directed that it did no execution. The regiments on the beach, after wasting a few musket shots, drew off. The English boarded the men of war, set them on fire, and having performed this great service without the loss of a single life, retreated at a late hour with the retreating tide. The bay was in a blaze during the night; and now and then a loud explosion announced that the flames had reached a powder room or a tier of loaded guns. At eight the next morning the tide came back strong; and with the tide came back Rooke and his two hundred boats. The enemy made a faint attempt to defend the vessels which were near Fort Saint Vaast. During a few minutes the batteries did some execution among the crews of our skiffs; but the struggle was soon over. The French poured fast out of their ships on one side: the English poured in as fast on the other, and, with loud shouts, turned the captured guns against the shore. The batteries were speedily silenced. James and Melfort, Bellefonds and Tourville, looked on in helpless despondency while the second conflagration proceeded. The conquerors, 
leaving the ships of war in flames, made their way into an inner basin where many transports lay. Eight of these ressels were set on firc. Several were taken in tow. The rest would bave been either destroyed or carried off, had not the sea again begrun to ebb. It was impossible to do more; and the victorious flotilla slowly retired, insulting the hostile camp with a thundering chant of "God save the King."

Thus ended, at noon on the twenty-fourth of May, the great conflict which had raged during five days over a wide extent of sea and shore. One English fire-ship had perished in its calling. Sixteen French men of war, all noble vessels, and eight of them three-deckers, had been sunk or burned down to the water-edge. The battle is called, from the place where it terminated, the battle of La Hogue.

Thomas Viabinglon. Macaulay'.

Trafalgar (1805)
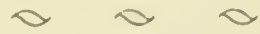

(From The lije of Neison)

A BOU'T half-past nine in the morning of the igth, the Mars, being the nearest to the flect of the ships which formed the line of communication with the frigates insbore, repeated the sigmal that the enemy were coming out of port. The 
wind was at this time very light, with partial breezes, mostly from the S.S.W. Nelson ordered the signal to be made for a chase in the south-east quarter. About two, the repeating ships announced that the enemy were at sea. All night the British fleet continued under all sail, steering to the southeast. At daybreak they were in the entrance of the Straits, but the enemy were not in sight. About seven, one of the frigates made signal that the enemy were bearing north. Upon this the Victory hove to ; and shortly afterwards Nelson made sail again to the northward. In the afternoon the wind blew fresh from the south-west, and the English began to fear that the foe might be forced to return to port. A little before sunset, however, Blackwood, in the Euryalus telegraphed that they appeared determined to go to the westward. "And that," said the admiral, in his diary, "they shall not do, if it is in the power of Nelson and Bronte to prevent them." Nelson had signified to Blackwood that he depended upon him to keep sight of the enemy. They were observed so well, that all their motions were made known to him; and, as they wore twice, he inferred that they were aiming to keep the port of Cadiz open, and would retreat there as soon as they saw the British fleet ; for this reason he was very careful not to approach near enough to be seen by them during the night. At daybreak the combined 
fleets were distinctly seen from the Victory's deck, formed in a close line of battle ahead, on the starboard tack, about twelve miles to leeward, and standing to the south. Our neet consisted of twenty-seven sail of the line and four frigates; theirs of thirty-three, and seven large frigates. Their superiority was greater in size, and weight of metal, than in numbers. They had four thousand troops on board; and the best riflemen who could be procured, many of them Tyrolese, were dispersed through the ships. Little did the Tyrolese, and little did the Spaniards, at that day imagine what horrors the wicked tyrant whom they served was preparing for their country! Soon after daylight Nelson came upon deck. The 2 rst October was a festival in his family, because on that day his uncle, Captain Suckling, in the Dreadnought, with two other line-of-battleships, had beaten off a French squadron of four sail of the line and three frigates. Nelson, with that sort of superstition from which few persons are entirely exempt, had more than once expressed his persuasion that this was to be the day of his battle also; and he was well pleased at seeing his prediction about to be verified. The wind was now from the west, light breczes, with a long heavy swell. Signal was made to bear down upon the enemy in two lines; and the fleet set all sail. Collingwood, in the fioyal Sovercignt, led the lec 
line of thirteen ships; the Victory led the weather line of fourtcen. . . .

Blackwood went on board the Victory about six. $\mathrm{He}$ found him in good spirits, but very calm; not in that exhilaration which he had felt upon entering into battle at Aboukir and Copenhagen; he knew that his own life would be particularly aimed at, and seems to have looked for death with almost as sure an expectation as for victory. His whole attention was fixed upon the enemy. They tacked to the northward, and formed their line on the larboard tack; thus bringing the shoals of Trafalgar and St. Pedro under the lee of the British, and keeping the port of Cadiz open for themselves. This was judiciously done; and Nelson, aware of all the advantages which it gave them, made signal to prepare to anchor. Villeneuve was a skilful seaman, worthy of serving a better master and a better cause. His plan of defence was as well conceived, and as original, as the plan of attack. He formed the fleet in a double line, every alternate ship being about a cable's length to windward of her second ahead and astern. Nelson, certain of a triumpliant issue to the day, asked Blackwood what he should consider as a victory. That officer answered, that, considering the handsome way in which battle was offered by the enemy, their apparent determination 
for a fair trial of strength, and the situation of the land, he thought it would be a glorious result if fourteen were captured. He replied: "I shall not be satisfied with less than twenty." Soon afterwards he asked him if he did not think there was a signal wanting. Captain Blackwood made answer that he thought the whole fleet scemed very clearly to understand what they were about. These words were scarcely spoken before that signal was made which will be remembered as long as the lauguage, or even the memory of England, shall endure-Nelson's last signal-" ENGLAND EXPECTS EVERY MAN TO DO HIS DUTY!" It was received throughout the fleet with a shout of answering acclamation, made sublime by the spirit which it breathed and the feeling which it expressed. "Now," said Lord Nelson, "l can do no more. We must trust to the Great Disposer of all events, and the justice of our cause. I thank God for this great opportunity of dloing my duty."

He wore that day, as usuil, his admiral's frock coat, bearing on the left breast four stars of the different orders with which he was invested. Ornaments which rendered him so conspicuous a mark for the enemy, were beheld with ominous apprehensions by his officers. It was known that there were riflemen on board the French ships; and it could not be doubted but that his tife would be particularly aimed at. They comnunicated their 
fears to each other; and the surgeon, Mr. Beatty, spoke to the chaplain, Dr. Scott, and to Mr. Scott, the public secretary, desiring that some person would entreat him to change his dress, or cover the stars: but they knew that such a request would highly displease him. "In honour I gained them," he had said when such a thing had been hinted to him formerly, "and in honour I will die with them." Mr. Beatty, however, would not have been deterred by any fear of exciting his displcasure, from speaking to him himself upon a subject in which the weal of England as well as the life of Nelson was concerned, but he was ordered from the deck before he could find an opportunity. This was a point upon which Nelson's officers knew that it was hopeless to remonstrate or reason with him; but both Blackwood, and his own captain, Hardy, represented to him how advantageous to the fleet it would be for him to keep out of action as long as possible; and he consented at last to let the Leviathan and the Temeraire, which were sailing abreast of the Victory, be ordered to pass ahead. Yet even here the last infirmity of this noble mind was indulged; for these ships could not pass ahead if the Victory continued to carry all her sail ; and so far was Nelson from shortening sail, that it was evident he took pleasure in pressing on and rendering it impossible for them to obey his own orders. A long 
swell was setting into the Bay of Cadiz: our ships, crowding all sail, moved majestically before it, with light winds from the south-west. The sun shone on the sails of the enemy ; and their wellformed line, with their numerous three-deckers, made an appearance which any other assailants would have thought formidable; but the British sailors only admired the beauty and the splendour of the spectacle; and, in full confidence of winning what they saw, remarked to each other, what a fine sight yonder ships would make at Spithead! The French admiral from the Bucentaure, beheld the new manner in which his encmy was advancing, Nelson and Collingwood each leading his line; and pointing them out to his officers, he is said to have exclaimed, that such conduct could not fail to be successful. Yet Villeneuve had made his own dispositions with the utmost skill, and the fleets under his command waited for the attack with perfect coolness. Ten minutes before twelve they opened their fire. Eight or nine of the ships immediately ahead of the Victory, and across her bows, fired single guns at her, to ascertain whether slue was yet within their range. As soon as Netson perceived that their shot passed over him, he desired 13lackwood, and Captain l'rowse, of the Sirius, to repair to their respective frigates; and, on their way, to tell all the captains of the line-of-battle ships that he depended on their 
exertions; and that, if by the prescribed mode of attack they found it impracticable to get into action immediately, they might adopt whatever they thought best, provided it led them quickly and closely alongside an enemy. As they were standing on the front of the poop, Blackwood took him by the hand, saying, he hoped soon to return and find him in possession of twenty prizes. He replied: "God bless you, Blackwood: I shall never see you again."

Nelson's column was steered about two points more to the north than Collingwood's, in order to cut off the cnemy's escape into Cadiz: the lee line, therefore, was first engaged. "See," cried Nelson, pointing to the Royal Sovereign, as she steered right for the centre of the enemy's line, cut through it astern of the Santa Anna, three-decker, and engaged her at the muzzle of her guns on the starboard side: "see how that noble fellow, Collingwood, carries his ship into action !" Collingwood, delighted at being first in the heat of the fire, and knowing the feelings of his commander and old friend, turned to his captain and exclaimed, "Rotherham, what would Nelson give to be here!" Both these brave officers, perhaps, at this moment thought of Nelson with gratitude, for a circumstance which had occurred on the preceding day. Admiral Collingwood, with some of the captains, having gone on board the Victory, to receive in- 
structions, Nelson inquired of him where his captain was, and was told, in reply, that they were not upon good terms with each other. "Terms!" said Nelson;-"good terms with each other!" Immediately he sent a boat for Captain Rotherham; led him, as soon as he arrived, to Collingwood, and saying, "Look; yonder are the enemy!" bade them shake hands like Englishnen.

The eneny comtinued to fire a gun at a time at the Victory, till they saw that a shot had passed through her main-top gallant-sail; then they opened their broadsides, aiming chiefly at her rigging, in the hope of disabling her before she could close with them. Nelson as usual, had hoisted several flags, lest one should be shot away. The enemy showed no colours till late in the action, when they began to feel the necessity of having them to strike. For this reason, the Santissima Trinidad, Nelson's old acquaintance, as he used to call her, was distinguishable only by her four decks; and to the bows of this opponent he ordered the Victory to be stecred. Meantime an incessant raking fire was kept up upon the Victory. 'The admiral's secretary was one of the first who fell : he was killed by a cannon shot, while conversing with Hardy. Captain Adair, of the marines, with the liclp of a sailor, endeavoured to remove the borly from Nelson's sight, who had a great regard for Mr. Scott; but he anxiously asked, "Is that 
poor Scott that's gone?" and being informed that it was indeed so, exclaimed, "Poor fellow!" Presently a double-headed shot struck a party of marines, who were drawn up on the poop, and killed eight of them: upon which Nelson immediately desired Captain Adair to disperse his men round the ship, that they might not suffer so much from being together. A few minutes afterwards a shot struck the fore brace-bits on the quarter-deck, and passed between Nelson and Hardy, a splinter from the bit tearing off Hardy's buckle and bruising his foot. Both stopped, and looked anxiously at each other, each supposing the other to be wounded. Nelson then smiled, and said, "This is too warm work, Hardy, to last long."

The Victory had not yet returned a single gun : fifty of her men had been by this time killed or wounded, and her main-topmast, with all her studding sails and their booms shot away. Nelson declared that, in all his battles, he had seen nothing which surpassed the cool courage of his crew on this occasion. At four minutes after twelve she opened her fire from both sides of her deck. It was not possible to break the enemy's line without running on board one of their ships: Hardy informed him of this, and asked which he would prefer. Nelson replied: "Take your choice, Hardy, it does not signify much." The master was then 
ordered to put the helm to port, and the Victory ran on board the Redoublable, just as her tiller ropes were shot away. The French ship received her with a broadside; then instantly let down her lower deck ports, for fear of being boarded through them, and never afterwards fired a great gun during the action. Her tops, like those of all the enemy's ships, were filled with riflemen. Nelson never placed musketry in his tops; he had a strong dislike to the practice; not merely because it endangers setting fire to the sails, but also because it is a murdcrous sort of warfare, by which individuals may suffer, and a commander, now and then, be picked off, but which never can decide the fate of a general engagement.

Captain Harvey, in the Temeraire, fell on board the Redoublable on the other side. Another enemy was in like manner on board the Temcraire: so that these four ships formed as compact a tier as if they had been moored together, their heads lying all the same way. The licutenants of the Victory, secing this, depressed their guns of the middle and lower decks, and fired with a diminished charge, lest the shot should pass through and injure the Temeraire. And because there was danger that the liedoubluble might take fire from the lower-deck guns, the muzzles of which touclied her side when they were run out, the fireman of each gun stood ready with a bucket of watcr, 
which, as soon as the gun was discharged, he dashed into the hole made by the shot. An incessant fire was kept up from the Victory from both sides; her larboard guns playing upon the Bucentaure and the huge Santissima Trinidud. It had been part of Nelson's prayer, that the British fleet might be distinguished by humanity in the victory which he expected. Setting an example himself, he twice gave orders to cease firing upon the Redoubtable, supposing that she had struck, because her great guns were silent; for, as she carried no flag, there was no means of instantly ascertaining the fact. From this ship, which he had thus twice spared, he received his death. A ball fired from her mizzen-top, which, in the then situation of the two vessels, was not more than fifteen yards from that part of the deck where he was standing, struck the epaulette on his left shoulder, about a quarter after one, just in the heat of the action. He fell upon his face, on the spot which was covered with his poor secretary's blood. Hardy, who was a few steps from him, turning round, saw three men raising him up. "They have done for me at last, Hardy," said he. "I hope not!" cried Hardy, "Yes," he replied; "my back bone is shot through." Yet even now, not for a moment losing his presence of mind, he observed, as they were carrying him down the ladder, that the tiller ropes, which had been shot 
away, were not yet replaced, and ordered that new ones should be rove immediately :-then, that he might not be seen by the crew, he took out his handkerchief, and covered his face and his stars. Had he but concealed these badges of honour from the enemy, England, perhaps, would not have had cause to receive with sorrow the news of the battle of Trafalgar. ....

Within a quarter of an hour after Nelson was wounded, about fifty of the Victory's men fell by the enemy's musketry. 'They, however, on their part, were not idle; and it was not long before there were only two Frenclinien left alive in the mizzen-top of the Redoubtuile. One of them was the man who had given the fatal wound: he did not live to boast of what he had done. An old quartermaster had seen him fire; and easily recognised him, because he wore a glazed cocked hat and a white frock. This quartermaster, and (wo midshijmen, Mr. Collingwood and Mr. Pollard, were the only persons left on the Victory's porsp; the two midshipmen kept firing at the top, and he supplied then with cartridges. One of the Frenchmen, attempting to make his escape down the rigging, was shot by Mr. l'ollard, and fell on the poop. But the old quartermaster, as he cried out, "That's he, that's he," and pointed at the other, who was coming forward to fire agatin 
received a shot in his mouth, and fell dead. Both the midshipmen then fired, at the same time, and the fellow dropped in the top. When they took possession of the prize, they went into the mizzentop, and found him dead; with one ball through his head, and another through his breast. The Redoulifable struck within twenty minutes after the fatal shot had been fired from her. During that time she had been twice on fire-in her fore chains and in her forecastle. 'The French, as they had done in other battles, made use, in this, of fireballs and other combustibles-implements of destruction which other nations, from a sense of honour and humanity, have laid aside-which add to the sufferings of the wounded, without determining the issue of the conbat-which none but the cruel would employ, and which never can be successful against the brave. Once they succeeded in setting fire, from the Redoublable, to some ropes and canvas on the Victory's booms. The cry ran through the ship, and reached the cockpit; but even this dreadful cry produced no confusion: the men displayed that perfect self-possession in danger by which English seamen are characterised: they extinguished the flames on board their own ship, and then hastened to extinguish them in the enemy, by throwing buckets of water from the gangway. When the Redoubtable had struck, it was not practicable to board her from the Victory; 
for, though the two ships touched, the upper works of buth fell in so much, that there was a great space between their gangways; and she could not be boarded from the lower or middle decks, because her ports were down. Some of our nien went to Lieutenant Quilliam, and offered to swim under her bows and get up there: but it was thought unfit to hazard brave lives in this manner. What our men would have done from gallantry, some of the crew of the Santissimu Trinidud did to save themselves. Unable to stand the tremendous fire of the Victory, whose larboard guns played against this great four-decker, and not knowing how else to escape them, nor where else to betake themselves for protection, many of them leapt overboard, and swam to the Victory; and were actually helped up her sides by the English during the action. The Spaniards legenan the battle with less vivacity than their unworthy allies, but they continued it with greater firmness. The Arginturutis and Buhamie were defended till they had each lost about four hundred men: ilic .S\%. Junn Nepomuceno lust three hundred and fifty. Often as the superiority of liritish courage hits been proved against France upoen the seas, it was never mure conspicuous that in this decisive conflur. Five of our ships were engaged muale to inusale with five of the firench. In all fise the lirenchunen lowered their leswer-ileck posts, and ileserted theis guns; 
while our men continued deliberately to load and fire, till they had made the victory secure.

\section{Robert Southey.}

Affair of the Chesapeake and Shannon (1813)

(From Britain's Sea-Kings and Sea-Fights)

HOWEVER galling it had been to the British to see frigate after frigate beaten, there was one man who had "spotted" the secret of the Americans' success. This was Captain Philip Bowes Vere Broke, of the Shannon. He knew that the British sailors possessed the same fine seamanly qualities as of yore, but that their captains had allowed drill to go rusty, and paid far too much attention to the polishing of brass and the holystoning of decks. Aboard his ship he had his men well in hand: in musketry and broadsword exercise they were as perfect as three hours' daily drill could make them, and the great guns were fired twice a week-a pound of 'bacca every time a man sent a shot through the bull's-eye. It was odd that public opinion looked to Broke as the man to retrieve Britain's glory. With this object in view he had taken the Shannon to the United States, destroying all his captures rather than reduce his crew by manning and sending in his prizes. To Captain John Lawrence, of the Chesa- 
perke, Broke sent several messages inviting him to come out of Boston harbour and try conclusions in the open. Probably these never reached him. At all events, as Broke got no answer he at last indited a polite letter to Lawrence requesting the favour of a ship-to-ship meeting. This challenge -which qucerly recalls, though its author was the reverse of a braggart, the missive sent by Sir John Cope from Dunbar to l'rince Charlie - was dated on the Ist of June, "the Glorious First," but ere it reached its destination, Captain Broke had the satisfaction of seeing from his masthead-whilst his men were dining - the Chesuperake fire a gun, leave her mooringrs, and make way towards him. Lawrence, not to be outdone in chivalry and courtesy, had sent ashore five of his guns, so as to equalise the armament. Each vessel carried twenty-five broadside guns, but the Shamnon only mustered 306 inen (1) the C'iesapeate's 376 , and the tonnage of the former was 10 , 6 to the latter's 1135 . We have seen, however, that Broke had an admirably trained and disciplined crew-'tis said he kept his decks constantly cleared for action-and he was probably more than satisfied to accept battle as he stood.

It almost reads like an arcount of one of those yacht races for the Anerica (up), to which Sir Thomas Lipton's patriotic ambition has accustomed us, to learn that as the Chesupentie left 
the harbour she was accompanied by scores of pinnaces, yachts, pleasure-boats, barges, and a schooner gunboat bearing several American naval officers-all longing to see the fun. Bostonian hearts beat high, and balls and suppers had already been ordered for the return of the conquering heroes. In one particular they set an example which the moderns have not yet copied-there was no difficulty about keeping the course; every boatload of sightseers was most scrupulously anxious to draw up well out of reach of the guns. At five minutes to I p.m. the Shannon stood out to sea under easy sail, and at one o'clock the Chesapeake rounded Boston lighthouse after her. When Captain Broke had got well into the open he shortened sail to permit his opponent to overtake him. It was late in the afternoon before the Chesapeuke drew near. She was then seen to be flying three ensigns: at the main floated the Stars and Stripes, and at the fore she displayed a big white banner with the legend, "Sailor's Rights and Free Trade." The motto implied Jack Tar's right to sail in any bottom he pleased (a dig at the search business), and the country's right to trade without the leave of Great IBritain, or France, or any other Power.

At 5.10 p.m. Captain Broke ordered his drums to beat to quarters, and the crew stood to their guns. Luckily the wind had fallen light, and 
there was little way on the vessel. Everything promised a fair and square fight. Within half an hour the Chesupeake was only two hundred yards away, and Broke seized the opportunity for a few final words to his men, urging them to remember that to their kecping had been committed the duty of asserting the superiority of British seamen over those of any other nation. W'e can almost hear the cmphatic "Ay, ay, sir," of the bronzed tars. At this stage the Shannon rave three cheers on their own account, which was readily taken up by the bystanding boits, stationed as we have seen, at quitc a respectful distance.

And now the fateful moment had come. The duellists were but a stone's throw apart. At ten minutes to six William Mindham, captain of the ginn, discharged the Shannon's aftermost mainderk grun. It was aimed with exquisite precision, as was the next, fired immediately afterwards, both doing terrible execution. The Chesapoutie then sent in a stingring retort, and by and by both ships were hotly engagerl, broadside after broadsitle b-ing discliarged as fast as the guns were loaded and erained. From the very first the superior accuracy of Broke's grumners asserted itself. Almost every shot produced yells of anguish, and splinters ro e up in rlourls. The Chesaperke forging ahead tor) rapridly was hatuled up, hue with helm uneuclied the man at the wheel was probably slain or 
wounded) and rigging and masts shot away, she came round so sharply as to stop almost entirely dead, and lying thus she got a dreadful punishment from her splendidly served foe. By six o'clock she actually drifted back upon the Shannon. Broke's boarders were quite ready, and, sword in hand, headed by their gallant captain, they leaped upon the quarter-deck of the Chesupeake and cleared the gangways with a furious charge. No man withstood that onset of British sailors armed with pike and bayonet, with cutlass and pistol. The handful of Americans who tried to stem the torrent were borne towards the forecastle, where they soon choked the hatchway in their panic. Some, terror-stricken, jumped into the sea; others submitted and were confined in the forecastle. Aboard the Chesapeake chaos had come again. Lawrence, her brave and honourable captain, lay dying, and most of her officers were killed or liurt. A few men in the shrouds, however, kept up a brisk and galling fire. Broke turned aside to order this to be put down. A warning cry from the sentry over the prisoners in the forecastle made him glance round, and just in the nick of time. Three stalwart Yankees had picked up weapons and were rushing upon him savagely. He parried one man's pike and damaged the fellow's face. The second man laid bare Broke's skull and partially stunned him. The 
third cut the captain down and was immediately cut down himself for his pains. Meanwhile a gallant middy, Bill Smith by name, and six sailors had jumped on the Chesapeake's main-yard and silenced the firing in her main-top. Smith then came down to help Mindham, and another man attended to the captain's injuries. Whilst bavingr his head bandaged, Broke saw his old ensign gu up over the Yankee's colours, and was satisficd. He was conveyed to the Chesapalk's quarter deck and seated on a grun. A bungle in the clangyingr of the culours, however, cost the life of the Shatmon's first licutcnant, Mr. Watt. Hauling duwn the American fag, he bent the English ensign below instead of above it, and ran it up. The blunder was observed before the thing were half way up to the mizzen peak; lout ere it could be rectified the men on the Shumnon, secing the Siripes gro up first, concluded the fighting was not yet done, and unwittingly began firing on their own folk on the quarter-clerk of the Chesupiake, Mr. Watl being killed and severill men wounded. As soon as the british ensign was huisted properly they recognised their disastrous error and ceased firing. Even now it scemed the Americans liad not yet hat enough, for they fired from the lobl and slew the sentry. At this the Britibls, justly incensed, poureel a volley intes the hold, whels fetclicel insiant sliricks for merry. ('ipheun lisulie: 
sent word that they must surrender at once if they wished for quarter. They gave in promptly, and the combat was over. At this moment Broke fainted from loss of blood and was carried in a jolly-boat to his own ship, which had dropped astern. There never was so short and sharp a fight. The pace was so fast and fierce that the whole thing was ended in twenty minutes. Lawrence having been twice wounded early in the action, was carried below. Asked whether the colours should be struck, he grimly answered, "No; they shall wave while I live." Then he grew delirious, and during his fever often exclaimed, "Don't give up the ship"-words which deservedly became classical in the American Navy.

$$
\text { James } A \text {. Manson. }
$$




\section{ENVOI}

The Sailor's Graveyard

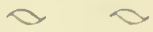

(From 7on. we's of Consicure)

IN the churclyard, growing grachually dim and ethereal, were laid many bodies from which the white vampires of the main had suched out the souls. Here muuldered fisher lads, who had whistled over the nets, and dreamed rough dreams of winuing island girls and breeding hardy children. Here reposed old limbs of salty mariners, who had for so long defied the ocean that when they knew themselves taken at the last, they turned their rugged faces duwn to their encmy with a stony and an ironic wonder. Ind here, tor, among these cast-up bodics of the drowned, lay many women who hat loved the prey of the seat, and kissed the elieeks turned acriel by its winds and waters. Some of them harl diced from heart-sickness, cursing the sea. Some hat facled, withering like the pulte sitnd-roses beside the seat.

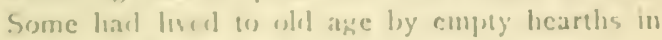
the seurnd of the sea.

Incriptens fided mpon the stones that lity 
above them. Texts of comfort in which the fine, salt films crept, faint verses of sweet hymns defiled by the perching sea-birds, old rhymes like homely ejaculations of very simple hearts, sank into the gathering darkness on every hand. The graves seemed murmuring to the night: "Look on me, I hold a lover"; "And I keep fast a maiden"; "And within my arms crumbles a little child caught by the sea"; "And I fold a mother, whose son is in the hideous water foliage of the depths of the sea"; "And I embrace an old captain whom the sea loved even in his hollow age."

Robert Hichens. 

This book is DUE on the last date stamped below.

DDURL BRE 2 F 13650 
AA 0005743315

\section{PLEACF DO NOT REMOVE} THIS BOOK CARD $-1$

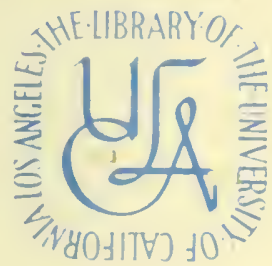

University Research Library

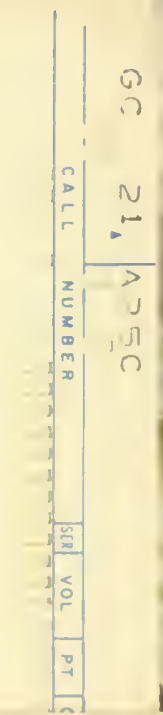


